\title{
Corals and carbon: \\ The physiological response of a protected deep-sea coral \\ (Solenosmilia variabilis) to ocean acidification
}

\section{Malindi J Gammon}

A thesis submitted to Victoria University of Wellington in partial fulfilment of the requirements for the degree of Masters of Science in Marine Biology

\section{6}

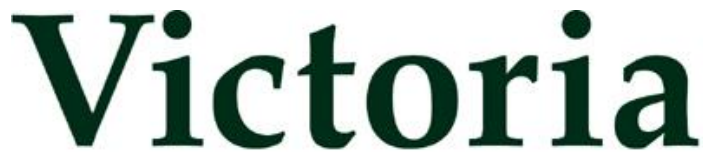

UNIVERSITY OF WELLINGTON

Te Whare Wānanga

o te Ūpoko o te Ika a Māui

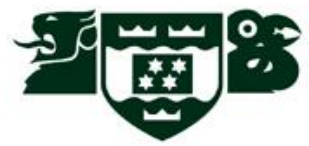

www,vuw,ac,nz 


\section{ABSTRACT}

Calcifying corals provide important habitat complexity in the deep-sea and are consistently associated with a biodiversity of fish and other invertebrates. Little is understood about how deep-sea corals may respond to predicted scenarios of ocean acidification (OA), but any predicted changes will have wider impacts on the ecosystem.

Colonies of Solenosmilia variabilis, a species of deep-sea coral found in the waters surrounding New Zealand, were collected during a cruise in March 2014 from the Louisville Seamount chain. Over 12-months, coral samples were maintained in temperature controlled $\left(\sim 3.5^{\circ} \mathrm{C}\right)$ continuous flow-through tanks. A control group of coral colonies was held in seawater with $\mathrm{pH}$ 7.88 and a treatment group in $\mathrm{pH}$ 7.65. These two $\mathrm{pH}$ levels were designed to reflect current $\mathrm{pH}$ conditions and end-of-century conditions, respectively. In addition to investigating changes in growth and morphology, measurements of respiration and intracellular $\mathrm{pH}(\mathrm{pHi})$ were taken after a mid-term (6 months for respiration; 9 months for $\mathrm{pHi})$ and long-term (12 months for both respiration and $\mathrm{pHi}$ ) exposure period.

An established method used in measuring the pHi of shallow water corals was adapted for use with deep-sea corals for the first time. pHi was independent from the seawater treatment and ranged from $7.67-8.30$. Respiration rate was not influenced by the reduced seawater $\mathrm{pH}$ tested here. Respiration rates were highly variable, ranging from 0.065 to $1.756 \mu \mathrm{g} \mathrm{O}_{2} \mathrm{~g}^{-1}$ protein $\mathrm{h}^{-1}$ and $\mathrm{pHi}$ ranged from $7.67-8.30$. Yearly growth rates were also variable, ranging from 0.53 to $3.068 \mathrm{~mm} \mathrm{year}^{-1}$, and again showed no detectable difference between the treatment and control colonies. However, a loss in the colouration of coral skeletons was observed in the treatment group and was attributed to a loss of tissue. This could indicate a reallocation of energy, 
allowing for the maintenance of those other physiological parameters measured here (e.g. growth and respiration rates). If this is indeed occurring, it would be consistent with the idea of phenotypic plasticity, where corals can alternate between soft-bodied and fossilizing forms, allowing them to survive past periods of environmental stress.

This research is an important first step towards understanding the sensitivity of deep-sea corals to $\mathrm{OA}$ and the potential for acclimation, and suggests that in many respects, S. variabilis might not be susceptible to end-of-century projections of OA. Nevertheless, the observed tissue loss is interesting and warrants further investigation to assess its long-term implications. Furthermore, the impacts of greater levels of OA, and the interactive effects of other ecological parameters such as food availability, need to be tested. 


\section{ACKNOWLEDGEMENTS}

There were so many people who helped me in the completion of this thesis and I dedicate the following pages to them:

To Simon Davy, my supervisor. Every student of science should be lucky enough to work with someone like you; to have the opportunity to tap into your brilliant mind.

To Di Tracey, thank you for the to-do lists over coffee and the science tales over dinner; you've introduced me to the deep-sea world, a world which I never want to leave.

To Emma Gibbin and Sushila Palau for saving me from my own confusion during my first encounters with ratiometric microscopy. To European expert, Connie Maier for your advice during the initial scoping of this work. I also thank Vonda Cummings for your ongoing encouragement, support and advice, Peter Marriott for your photographic eye, and Graeme Moss and Neil Barr for your support. To Christine Bylenga and Sonja Hempel for not only helping to feed the corals, but also for your humour and morale.

To the NIWA vessel RV Tangaroa and all those who have sailed with her. To Malcolm Clark and Di Tracey for believing in me enough to send me to sea and to Mother Nature for putting on a show.

To my parents, my tireless cheerleaders; thank you for your endless words of encouragement, the home cooked meals and listening ears. To my wonderful friends, thank you for understanding my absence, for a much needed laugh or glass of Sav. A Particular thanks to Freya O’Meara for your eye for detail and the coffee and fresh-air exactly when I needed it. 
I acknowledge the Ministry for Primary Industries, particularly Mary Livingston for supporting the project, and to NIWA for providing research space, expertise and support. To Kate Sparks and Miles Lamare (Department of Marine Science, University of Otago) I acknowledge the loan of respiration chambers, and from Kate a clear word.

And finally to the corals, the pathway to completion of this thesis will be forever littered with your perplexing beauty. 


\section{TABLE OF CONTENT}

\section{Introduction}

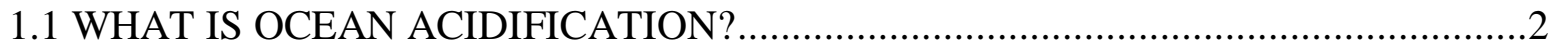

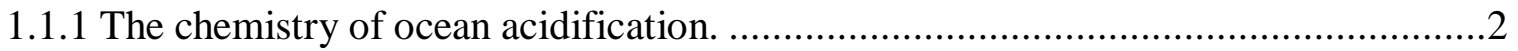

1.1.2 Saturation horizons in the marine environment .........................................

1.1.3 The implications of ocean acidification on marine life ..................................6

1.1.4 Ocean acidification and the deep-sea ......................................................

1.1.5 Deep-sea corals and ocean acidification............................................... 10

1.2 THE STUDY SPECIES: SOLENOSMILIA VARIABILIS....................................21

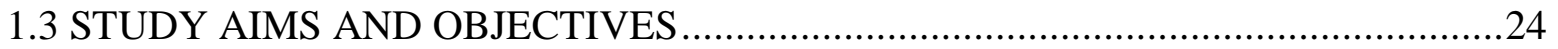

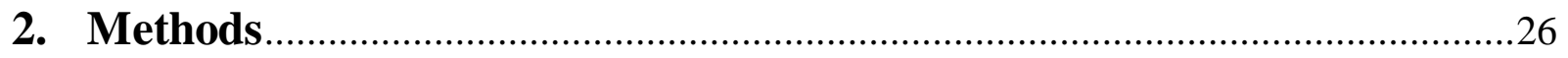

2.1 AT-SEA SAMPLING OF SOLENOSMILIA VARIABILIS....................................27

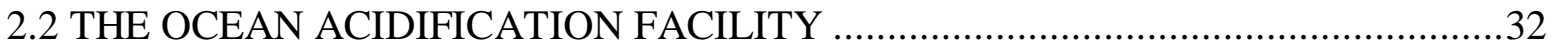

2.3 THE EXPERIMENT: EXPOSURE OF SAMPLES TO HIGH $\mathrm{pCO}_{2} \ldots \ldots \ldots \ldots \ldots \ldots \ldots . . . . . . . . . . .34$

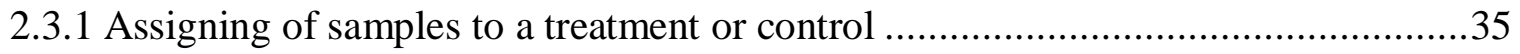

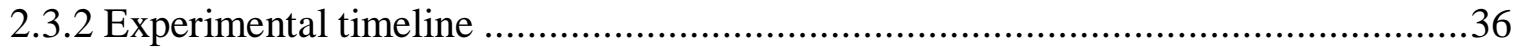

2.4 QUANTIFYING GROWTH, MORPHOLOGY AND HEALTH ............................39

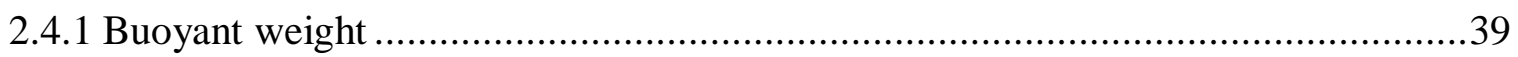

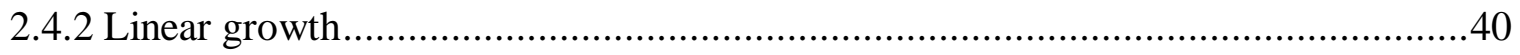


2.4.3 Polyp mortality. 41

2.4.4 Loss of coenosarc........ 42

2.4.5 Respiration rate 47

2.5 MEASUREMENTS OF INTRACELLULAR pH (pHi) ......................................50

2.5.1 Using SNARF-1 to measure pHi of Solenosmilia variabilis ................................51

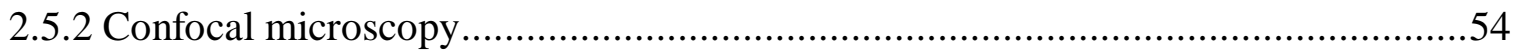

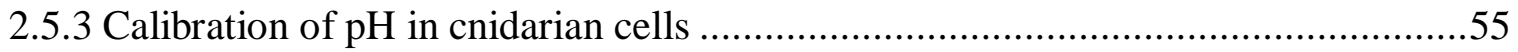

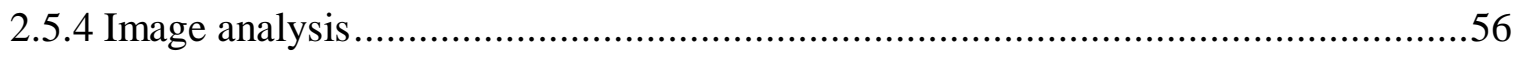

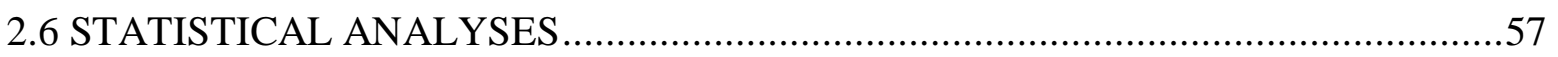

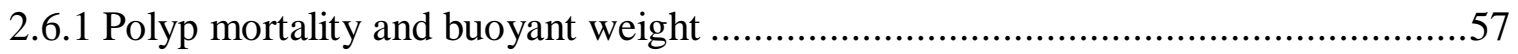

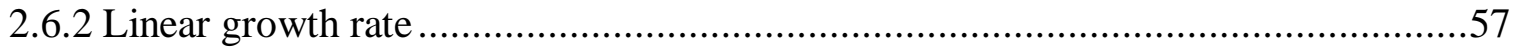

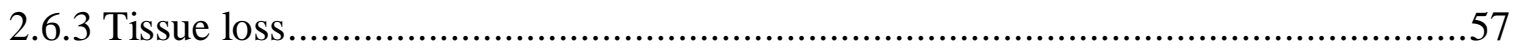

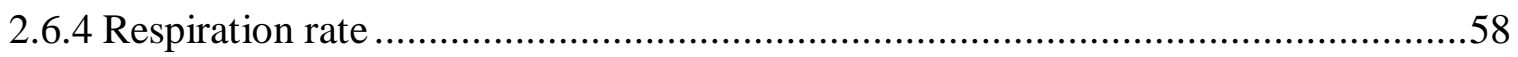

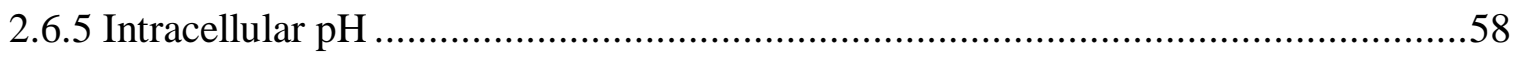

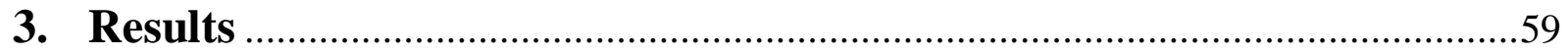

3.1 COLONY GROWTH, MORPHOLOGY AND HEALTH ...................................60

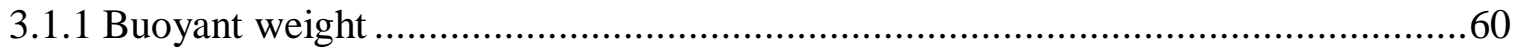

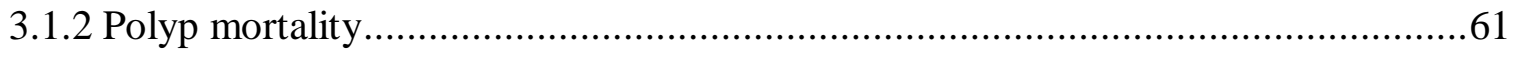

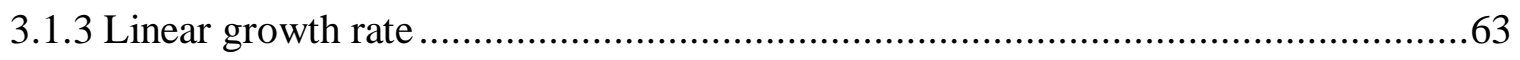

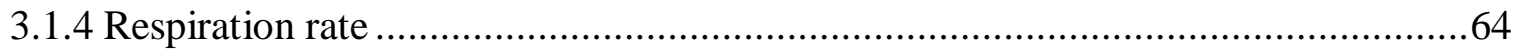


3.1.5 Tissue (coenosarc) loss. .66

3.2 INTRACELLULAR PH 68

4. Discussion .71

4.1 SUMMARY OF FINDINGS 72

4.2 THE IMPACTS OF OA ON THE GROWTH AND MORPHOLOGY OF

SOLENOSMILIA VARIABILIS .74

4.3 THE IMPACTS OF OA ON THE RESPIRATION RATE OF SOLENOSMILIA VARIABILIS .77

4.4 THE IMPACTS OF OA ON THE pHi OF SOLENOSMILIA VARIABILIS. .79

4.5 WHAT IS THE FUTURE FATE OF SOLENOSMILIA VARIABILIS AND OTHER DEEP-SEA CORALS?.

4.5.1 What are the different responses to environmental change that may be shown by Solenosmilia variabilis and other deep-sea corals?..... .84

4.5.2 Can Solenosmilia variabilis and other deep-sea corals adapt to ocean acidification?

4.5.3 Can Solenosmilia variabilis and other deep-sea corals migrate to a refuge?

4.6 FUTURE WORK FOR OA RESEARCH ON SOLENOSMILIA VARIABILIS AND

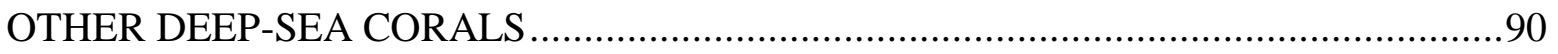

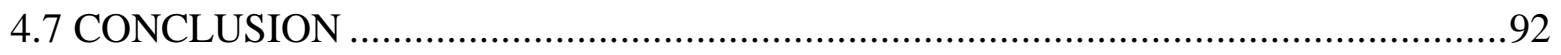

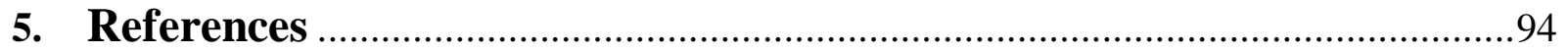




\section{LIST OF FIGURES}

Figure 1.1: The chemical process that occurs when anthropogenic carbon dioxide is absorbed by the ocean.

Figure 1.2: The depth distribution of the aragonite saturation horizon. ..................................

Figure 1.3: Known distribution of deep-sea and cold-water corals globally ..........................11

Figure 1.4: Image of Solenosmilia variabilis showing polyp tentacles retracted into the corallite depression.

Figure 1.5: Live branching Solenosmilia variabilis corals in situ located on seamount features on the Chatham Rise within New Zealand's Exclusive Economic Zone. .14 Figure 1.6: Distribution and depth data for Solenosmilia variabilis in the New Zealand region

Figure 2.1: The National Institute of Water and Atmosphere (NIWA) seamount sled. .27

Figure 2.2: Track of RV Tangaroa during TAN1402 to the Louisville Seamount ridge, east of New Zealand. .28

Figure 2.3: On-board aquarium where live Solenosmilia variabilis colonies were kept during the voyage. .30

Figure 2.4: The Ocean Acidification Facility at NIWA's Greta Point. .33

Figure 2.5: Image of a live Solenosmilia variabilis fragment used in this experiment. .36

Figure 2.6: A schematic diagram of the experimental timeline. .38

Figure 2.7. Images of a Solenosmilia variabilis colony fragment taken at bi-monthly intervals. 
Figure 2.8: The relative change in intensity of each of the red, green and blue (RGB) colour channels in images of Solenosmilia variabilis colony fragments, taken over 12 months.

Figure 2.9: The relationship between coral health index of Solenosmilia variabilis fragments and the relative loss in intensity of each of the red, blue and green colour channels. .46

Figure 2.10: The respiration chambers used to measure respiration rates of live Solenosmilia variabilis.

Figure 2.11: Fragment of the deep-sea coral Solenosmilia variabilis in a respiration chamber.

Figure 2.12: The emission spectrum of the ratiometric dye SNARF-1 at different pH levels..51 Figure 2.13: A confocal image of Solenosmilia variabilis coral cells incubated in the $\mathrm{pH}$ dependent probe SNARF-1 and imaged with a confocal microscope .53

Figure 2.14: An isolated Solenosmilia variabilis cell incubated in the fluorescent probe

SNARF-1 and showing the background fluorescent signal.

Figure 2.15: Calibration of the intracellular $\mathrm{pH}(\mathrm{pHi})$ of isolated Solenosmilia variabilis cells with the fluorescent ratio signal of SNARF-1. .56

Figure 3.1: The effect of seawater $\mathrm{pH}$ on buoyant weight (\% of initial weight remaining) of Solenosmilia variabilis.

Figure 3.2: A visualization of polyp mortality in Solenosmilia variabilis, resulting from reduced seawater $\mathrm{pH}$. .61

Fig. 3.3 The effect of seawater $\mathrm{pH}$ on the average polyp mortality in Solenosmilia variabilis.

Figure 3.4: The impacts of external $\mathrm{pH}$ on the linear growth rate of the deep-sea coral Solenosmilia variabilis. .64 
Figure 3.5: The effect of seawater $\mathrm{pH}$ on the respiration rate of Solenosmilia variabilis .65 Figure 3.6: The effect of seawater $\mathrm{pH}$ on the loss of coenosarc tissue of the coral Solenosmilia variabilis.

Figure 3.7: Multiple and isolated Solenosmilia variabilis cells incubated in the fluorescent probe SNARF-1.

Figure 3.8: The impact of the external $\mathrm{pH}$ of seawater on the intracellular $\mathrm{pH}(\mathrm{pHi})$ of isolated Solenosmilia variabilis cells. 70

Figure 4.1: The different types of response to an environmental stressor.................79 Figure 4.2: The response of the deep-sea coral Solenosmilia variabilis to ocean acidification. 


\section{LIST OF TABLES}

Table 2.1. A summary of the seamounts that were successfully sampled for live coral

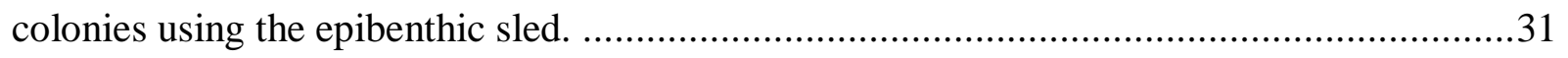

Table 2.2. A summary of water chemistry at the sample sites...............................32

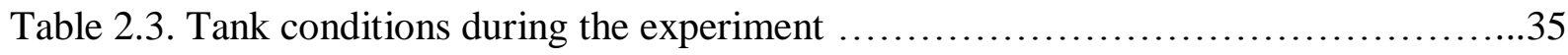




\section{ABBREVIATIONS}

$\Omega$ : Saturation state

ANCOVA: Analysis of Covariance

ANOVA: Analysis of Variance

AFDW: Ash Free Dry Weight

ASH: Aragonite Saturation Horizon

$\mathrm{CaCO}_{3}$ : Calcium carbonate

$\mathrm{CO}_{3}^{2-}$ : Carbonate ion

CSH: Calcite Saturation Horizon

$\mathrm{CO}_{2}$ : Carbon Dioxide

DIC: Dissolved Inorganic Carbon

FSW: Filtered Sea-Water

$\mathrm{H}^{+}$: Hydrogen ion

$\mathrm{H}_{2} \mathrm{CO}_{3}$ : Carbonic acid

$\mathrm{HCO}_{3}{ }^{-}$: Bicarbonate ion

IPCC: Intergovernmental Panel on Climate Change

NIWA: National Institute of Water and Atmosphere

$\mathrm{O}_{2}$ : Oxygen

OA: Ocean Acidification

$\mathrm{pCO}_{2}$ : Partial Pressure of Carbon Dioxide

pHe: External pH

pHi: Intracellular $\mathrm{pH}$

SE: Standard Error

rm-ANOVA: repeated measures Analysis of Variance

TA: Total alkalinity 
1. Introduction 


\subsection{WHAT IS OCEAN ACIDIFICATION?}

\subsubsection{The chemistry of ocean acidification.}

Atmospheric concentrations of carbon dioxide $\left(\mathrm{CO}_{2}\right)$ have increased by $\sim 40 \%$ since preindustrial times due to anthropogenic emissions (Tans \& Keeling, 2011). This atmospheric $\mathrm{CO}_{2}$ is a greenhouse gas which contributes to global climate change (Hansen et al. 1981; IPCC, 2013). Areas prone to both droughts and floods, large-scale erosion and melting of polar ice caps, are all expected results of climate change (Hansen et al. 1981; IPCC, 2013), and the effects of global climate change on both biodiversity loss (Parmesan \& Yohe, 2003) and sea level rise (Church \& White, 2006) are already evident.

The ocean absorbs much of this atmospheric $\mathrm{CO}_{2}$, with estimates of carbon sequestration ranging from $\sim 25 \%-50 \%$ (Canadell et al. 2007). While it removes harmful $\mathrm{CO}_{2}$ from the atmosphere, ocean sequestration of $\mathrm{CO}_{2}$ creates an additional problem: changes to the chemistry of seawater. Ocean acidification (OA) is the collective term used to describe the changes to oceanic chemistry that occur when the ocean absorbs anthropogenic $\mathrm{CO}_{2}$. When $\mathrm{CO}_{2}$ is dissolved in seawater, through a series of chemical reactions (Fig. 1.1), carbonic acid is formed which then partly dissociates and releases some hydrogen ions. These hydrogen ions are then neutralized by reacting with carbonate ions to form bicarbonate ions. This chain of reactions both reduces the availability of free carbonate ions and the $\mathrm{pH}$ of seawater (Kleypas et al. 1999; Hoegh-Guldberg et al. 2007; Howard et al. 2012). 


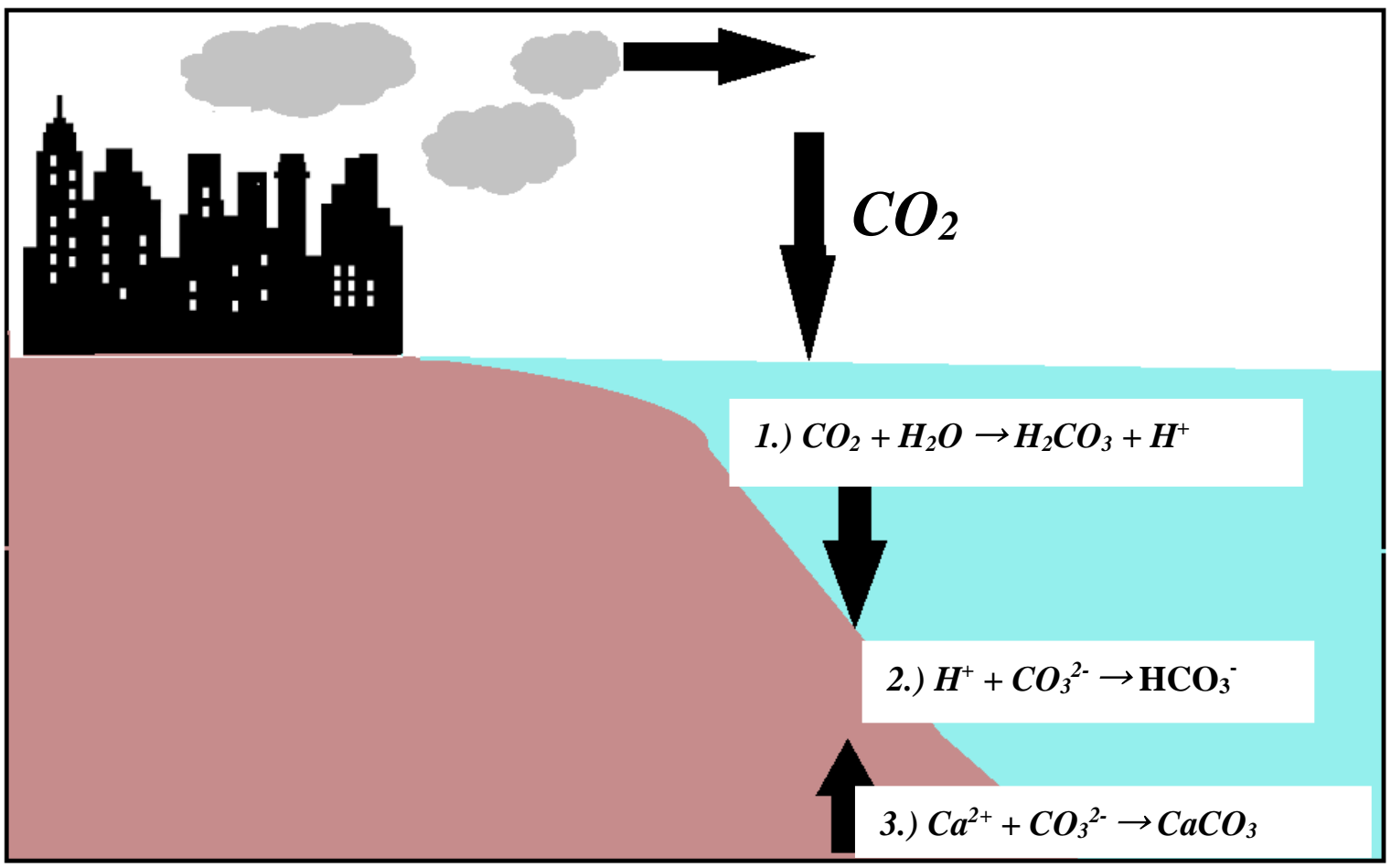

Figure 1.1: The chemical process that occurs when carbon dioxide is absorbed by the ocean. Carbon dioxide $\left(\mathrm{CO}_{2}\right)$ reacts with seawater to produce carbonic acid $\left(\mathrm{H}_{2} \mathrm{CO}_{3}\right)$ and hydrogen ions $\left(\mathrm{H}^{+}\right)$(equation one). These hydrogen ions combine with carbonate ions $\left(\mathrm{CO}_{3}{ }^{2-}\right)$, producing bicarbonate ions $\left(\mathrm{HCO}_{3}{ }^{-}\right)$(equation two). The creation of bicarbonate, through the addition of $\mathrm{CO}_{2}$, makes carbonate ions, an important product in the process of calcification (equation three) unavailable for calcifying organisms. As the atmospheric concentration of $\mathrm{CO}_{2}$ increases, the amount of carbonate available for calcifying organisms decreases.

By the end of this century, $\mathrm{OA}$ is expected to cause a drop in oceanic $\mathrm{pH}$ by $0.2-0.3 \mathrm{pH}$ units (Howard et al. 2012; IPCC, 2013), and $\mathrm{pH}$ has already dropped by 0.1 units since pre-industrial times (Friedrich et al. 2012). OA and the associated changes to the chemistry of seawater are not limited to local impacts. Instead, these changes will occur over the entire ocean, although exact changes may be more concentrated in some areas than others. The deep-sea and polar 
regions will be particularly impacted where the cold temperatures, changes in ocean chemistry, and slower physiological processes mean that marine animals will struggle to survive (Widdicombe \& Spicer, 2008).

\subsubsection{Saturation horizons in the marine environment}

There are three commonly occurring mineral phases of carbonate in the marine environment: aragonite, calcite and magnesian-calcite. By reducing the availability of carbonate ions, OA reduces the saturation state $(\Omega)$ of each of these minerals (Gattuso \& Hansson, 2011). $\Omega$ is defined as the ratio between the observed ion product and the expected ion product. Seawater is in equilibrium with that mineral when $\Omega=1$; supersaturated when $\Omega>1$ (whereby precipitation of that mineral is promoted); and undersaturated when $\Omega<1$ (whereby dissolution of that mineral is promoted) (Gattuso \& Hansson, 2011) (Fig. 1.2). Surface waters are supersaturated with the three mineral phases of carbonate. 


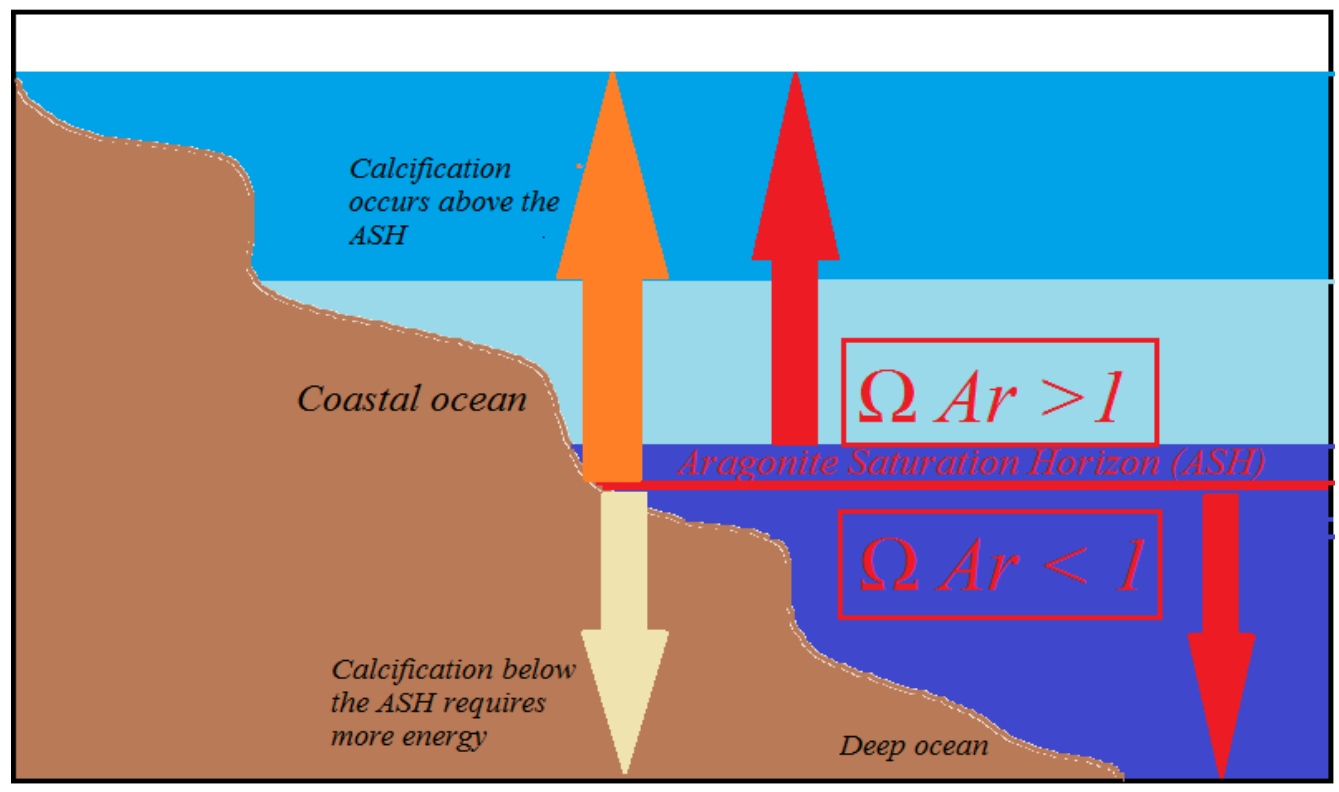

Figure 1.2: The depth distribution of the aragonite saturation horizon. Below the aragonite saturation horizon, seawater is under-saturated with aragonite and calcification of aragonite requires more energy. Above this horizon, seawater is saturated with aragonite and calcification requires less energy. Calcifying organisms thrive above this saturation horizon and occur less frequently below it.

For each mineral form of carbonate there exists an individually and naturally occurring saturation horizon. The saturation state of a mineral decreases as a function of depth (owing to increasing pressure and decreasing temperature) and the saturation horizon of a mineral is the depth where $\Omega=1$. Below this horizon, $\Omega<1$ and above this horizon $\Omega>1$ (Gattuso \& Hansson, 2011). Due to the different solubility properties of the different mineral forms of carbonate, their saturation horizons occur at different depths. Calcite is more soluble than aragonite and thus the aragonite saturation horizon (ASH) is shallower than the calcite saturation horizon (CSH). Magnesium-calcite is the least soluble carbonate mineral form, and has the shallowest 
saturation horizon. The depth of the ASH varies with oceanic basin and is shallower in the Pacific Ocean than in the Atlantic Ocean (Morse \& Mackenzie, 1990).

\subsubsection{The implications of ocean acidification on marine life.}

\section{Impacts of ocean acidification on the individual}

At the individual and cellular levels, all organisms are likely to be impacted by OA through acid-base imbalance and a reduced capacity for the transport of oxygen (Fabry et al. 2008). As the ocean absorbs more $\mathrm{CO}_{2}$, and the partial pressure of $\mathrm{CO}_{2}\left(\mathrm{PCO}_{2}\right)$ in seawater increases, $\mathrm{CO}_{2}$ more readily diffuses across animal surfaces. Within an animal cell, the internal level of $\mathrm{CO}_{2}$ continues to rise until a sufficient level of $\mathrm{CO}_{2}$ is achieved to facilitate diffusion out of the cell. This elevated level of internal $\mathrm{CO}_{2}$ is known as hypercapnia. As with seawater, $\mathrm{CO}_{2}$ reacts with internal body fluids, hydrogen ions are created, and the internal $\mathrm{pH}$ declines. A reduction of the internal $\mathrm{pH}$ of cells can lead to cellular acidosis. Intracellular $\mathrm{pH}(\mathrm{pHi})$ plays a key role in the healthy functioning of organisms and optimal cell functioning (e.g. ion transport, enzyme activity and protein functioning) and is dependent on pHi being maintained within narrow limits (Smith \& Raven, 1979, Casey et al. 2010). For example, a key-enzyme in the glycolytic metabolic pathway exhibits a 10 - to 20 -fold reduction in concentration when $\mathrm{pH}$ decreases by as little as 0.1 units below ambient levels (Trivedi \& Danforth, 1966). Many marine organisms have mechanisms to deal with this decrease in pHi, including: (a) passive buffering of intracellular fluids; (b) transport and exchange of relevant ions; (c) transport of $\mathrm{CO}_{2}$ in the blood in those species that have respiratory pigments; and (d) metabolic depression to wait out periods of elevated $\mathrm{CO}_{2}$ (Fabry et al. 2008 and references therein). 
Changes to the $\mathrm{pH}$ of seawater also interfere with blood-oxygen binding of marine organisms. As in fishes, many marine animals rely on specialised respiratory proteins to bind oxygen at respiratory surfaces. This oxygen is then delivered to tissues for metabolism. $\mathrm{CO}_{2}$ produced by cellular metabolism interacts with body fluids to produce hydrogen ions that bind to respiratory proteins, altering their affinity for oxygen (Fabry et al. 2008 and references therein). Furthermore, an organism's sensory ability may also be impacted by OA, as has been seen in many fish species (Munday et al. 2009, Simpson et al. 2011). An impairment of sensory ability would limit the capability of many predator species to seek out their prey and would also limit the capability of many prey species to escape their predators (Ferrari et al. 2010).

\section{Ecosystem and species interactions}

Environmental change has an impact on species interactions, population dynamics and community structure. The environmental changes associated with OA have the potential to create widespread changes to marine ecosystems (Fabry et al. 2008) and OA has been identified as a major threat to life in the ocean (Hoegh-Guldberg et al. 2007). The impacts of OA are predicted to be far-reaching, affecting all units of biology, from the individual through to ecosystem functioning.

Different species will however, have different tolerances to the environmental changes that are predicted as a result of $\mathrm{OA}$, and these different tolerances could influence an organism's role within an ecosystem. For example, species-specific changes in the energy requirements of physiological processes, such as respiration and calcification, have been observed in coastal mussels exposed to reduced $\mathrm{pH}$ conditions, and these divergent patterns of energy allocation may influence competitive interactions among these different species (Kroeker et al. 2014). 


\section{The impacts of ocean acidification on calcification}

Calcification involves the accumulation of calcium carbonate $\left(\mathrm{CaCO}_{3}\right)$ in the body tissue of various marine fauna and results in the development of a shell or exoskeleton. $\mathrm{CaCO}_{3}$ structures are present in many ecologically important marine organisms including crustaceans, cnidarians, bryozoans, sponges and brachiopods. Planktonic organisms, which form the basis of many food webs, such as coccolithophores and foraminiferans, also produce $\mathrm{CaCO}_{3}$ structures. Furthermore, gravity sensory organs such as the ear bone or otolith of many fishes also contain calcium minerals (Lowenstam \& Weiner, 1989). Because the process of calcification requires calcium and carbonate ions from seawater, the physiology, habitat and structure of these organisms are strongly controlled by the chemistry of seawater.

As previously mentioned, the changes to the chemistry of seawater, which result from OA, cause a reduction in the saturation state of the three mineral phases of carbonate. The reductions in saturation state, which have already been observed due to OA (Takahashi et al. 2006), have reduced the availability of carbonate ions in seawater, and as a result the calcification rate of calcifying organisms has declined (Gattuso et al. 1999; Langdon et al. 2000; Hofmann et al. 2010). Some specific examples of reductions in calcification as a result of OA, include: Calcification in foraminiferans, which has already declined $30-35 \%$ since pre-industrial times (Moy et al. 2009); and in situ observations of a reef in Papua New Guinea that is naturally exposed to $\mathrm{CO}_{2}$ seeps, where reef development (the accumulation of $\mathrm{CaCO}_{3}$ structures) has ceased below a pH of 7.7 (Fabricius et al. 2011). Furthermore, shell and skeleton dissolution rates of calcifying organisms increase under conditions of reduced $\mathrm{pH}$ and carbonate saturation state (Feely et al. 2004). 
The process of calcification requires more energy in seawater with reduced $\mathrm{pH}$ (Wood et al. 2008). Creation of $\mathrm{CaCO}_{3}$ during calcification produces hydrogen ions that must be expelled by the organism to the surrounding seawater. Because expulsion of hydrogen ions from an organism's internal environment is an active process, going from an area of low hydrogen ion concentration to high hydrogen ion concentration, it requires energy (Jokiel et al. 2013). As the $\mathrm{pH}$ of seawater reduces, and the concentration of hydrogen ions in seawater increases, the expulsion of hydrogen ions from an organism's internal environment requires more energy (Jokiel et al. 2013). This is because an increase in the concentration of external hydrogen ions, increases the ion concentration gradient across which hydrogen ions must be expelled and the energy required to transport ions against an ion gradient increases proportionally to the strength of that gradient (Jokiel, 2013).

\subsubsection{Ocean acidification and the deep-sea}

The deep-sea can be defined as those areas of the ocean beyond the continental shelf. Deep-sea animals are adapted to low-energy lifestyles and have reduced rates of metabolism and growth (Glover \& Smith, 2003). It is predicted that deep-sea organisms will be among the first and most affected by OA due to a shoaling of the ASH and CSH. The location of the ASH places a strong control on the location and depth at which calcifying organisms can thrive. Below the ASH, seawater is corrosive to aragonite. This means that dissolution of aragonite structures occurs and must be off-set by continued calcification, and therefore calcification below the ASH requires more energy than it does above the ASH (Guinotte et al. 2006; Roberts et al. 2006; Wood et al. 2008). 
As OA reduces the concentration of calcium carbonate in seawater, the depth of the ASH shoals (Feely et al. 2004; Andersson et al. 2008). The Intergovernmental Panel on Climate Change (IPCC) predicts that the ASH will reach the surface in the Southern Ocean by 2050 and will shoal more than 1,000 $\mathrm{m}$ in the South Pacific and between 800 and 2, $200 \mathrm{~m}$ in the Atlantic by 2100 (IPCC, 2013). Shoaling of the ASH will place organisms previously found in water that is supersaturated with carbonate in water that is under-saturated with carbonate. It has been proposed that some organisms may be able to up-regulate their metabolism to cope with the energetic demands of calcification under reduced $\mathrm{pH}$ and carbonate conditions (Wood et al. 2008). This re-allocation of energy would have important implications for other energetic requirements, such as predator avoidance and reproduction. It is also not known whether such a strategy could be engaged long-term however.

\subsubsection{Deep-sea corals and ocean acidification}

\section{What are deep-sea corals?}

Deep-sea corals (also referred to as cold-water corals) provide important habitat complexity in the deep-sea and the reefs they form are biodiversity hot spots (Roberts et al. 2006). They are among the most spatially complex known deep-sea habitats, and are associated with a high diversity of fish and other invertebrates (Roberts et al. 2006; Clark \& Rowden, 2009). The function of deep-sea coral reef ecosystems have been likened to that of their shallow water counterparts, providing enhanced feeding opportunities, protection from predators, refuge, and a nursery and spawning site for juvenile fishes (Roberts et al. 2009). Furthermore, many of these juvenile fishes, which rely on coral habitat for protection from predators and increased feeding opportunities, are commercially important (Koslow et al. 2000). 
Deep-sea corals are found globally (Fig. 1.3) and are restricted to water temperatures between $4^{\circ}$ and $12{ }^{\circ} \mathrm{C}$ (Roberts et al. 2006; Buhl-Mortensen, 2005). This corresponds to relatively shallow depths (between 50 to $1000 \mathrm{~m}$ ) at high latitudes and greater depths (up to $4000 \mathrm{~m}$ ) at low latitudes (Roberts et al. 2006). While approximately 800 species of shallow water reefbuilding corals have been described, only ten deep-sea reef-building corals have been described (Freiwald et al. 2004; Cairns 1979). Due to their location (at depth) it is likely that there are still many taxonomically un-described and undiscovered deep-sea coral species.

Deep-sea corals may occur individually as isolated thickets or collectively as a coral reef (Fig.1.4 - 1.5), sometimes forming large carbonate mounds up to $300 \mathrm{~m}$ high (Roberts et al. 2006). Reef development is initiated after a coral larva settles to a hard substrate. As a coral colony develops, older polyps die and that section of dead coral becomes vulnerable to bioeroders and dissolution (Roberts et al. 2006). These vulnerable sections often break off, fall to the seabed and extend the perimeter of carbonate material around a reef bed (Roberts et al. 2006). This is an important process in the development of a reef.

The coral animal is the polyp, and in stony corals this is supported by a calcium carbonate exoskeleton (Fig. 1.4) (Sherwood et al. 2005; Roberts et al. 2009) that in most deep-sea corals consists of aragonite (Bostock et al. 2015). Deep-sea corals are widely distributed on seamounts (Tracey et al. 2011; Davies \& Guinotte, 2014) where secretion of their exoskeleton forms a basic reef structure (Smith \& Kinsey, 1976). Deep-sea corals branch and form polyps in a unique three-dimensional way, forming a matrix like structure (Cairns, 1979). Coenosarc, also known as coenochyme, is the living tissue of the coral and this connects each polyp. Polyps are also interconnected by a complex and well-developed system of gastrovascular canals, allowing significant sharing of nutrients. The polyps sit in cup-shaped depressions in the skeleton known 
as corallites (Fig. $1.4-1.5$ ). The mouth of each polyp is surrounded by a ring of tentacles that retract and extend regularly, feeding on nutrients suspended in the water column (Fig. 1.4 - 1.5). The polyp also has a reproductive role.

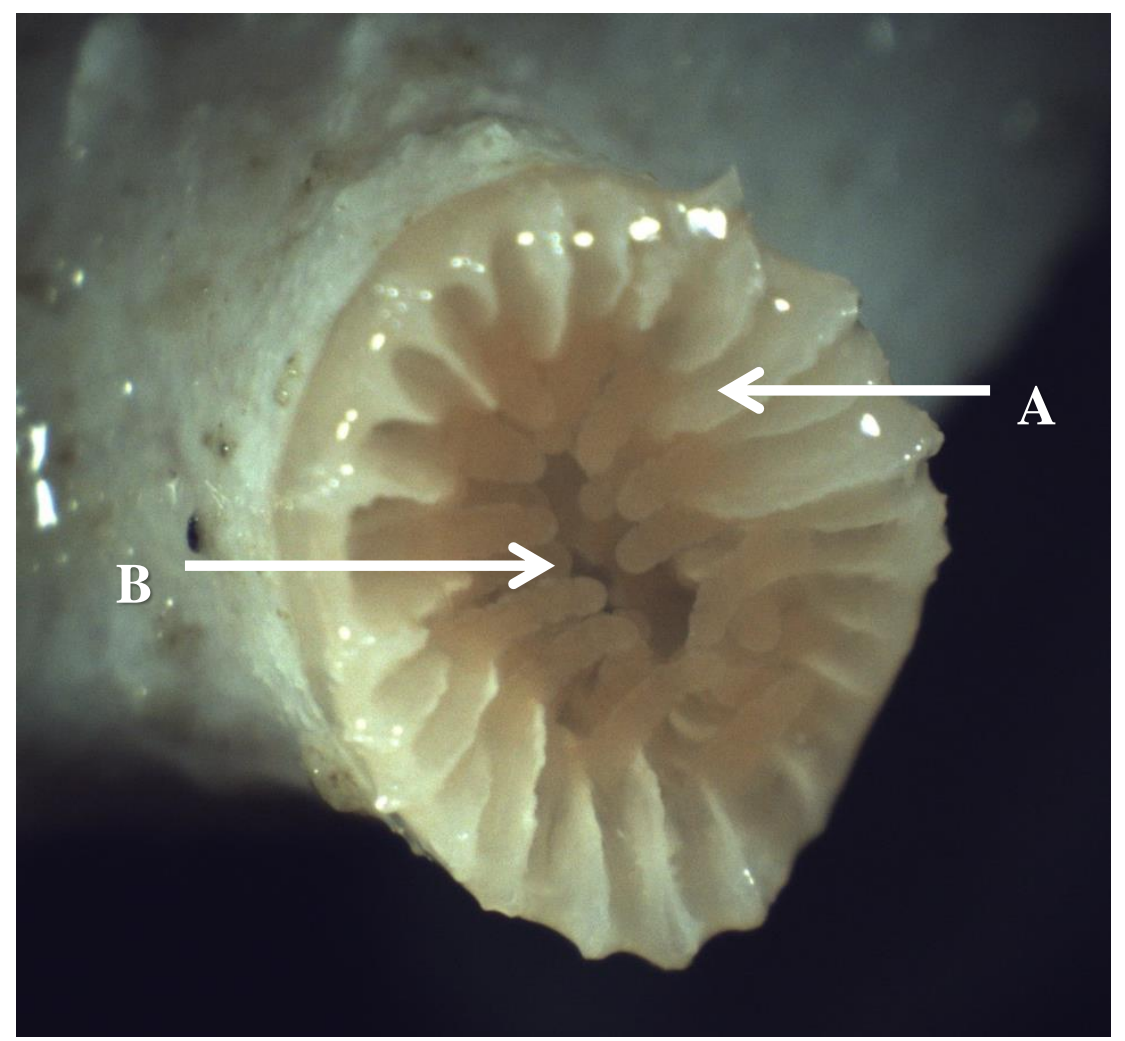

Figure 1.4: Image of Solenosmilia variabilis showing polyp tentacles retracted into the corallite depression. The arrows indicates a corallite depression where a polyp sits (A) and live polyp tentacles retracting into the colony cup (B) (Image: NIWA).

There is little information on the reproductive biology of deep-sea corals. However, fecundity can be predicted by measurements of the number of reproductive oocytes per polyp (Burgess, 2002; Waller \& Tyler, 2005). The large number of small oocytes that are found in the reproductive polyps of many deep-sea corals suggests that they are broadcast spawners (Burgess, 2002; Waller \& Tyler, 2005). While most shallow water corals are hermaphrodites, it 
is thought that the majority of deep-sea corals are gonochoristic (Roberts et al. 2006). Gamete production in Lophelia pertusa is initiated by seasonally enhanced fluxes of primary production from surface waters, which are associated with spring phytoplankton blooms (Freiwald et al. 2004). A similar process may initiate gamete production in other deep-sea coral species.

Deep-sea corals feed on nutrients in the water column that originate from primary production in surface waters (Duineveld et al. 2004). Relying only on these nutrients from the overlaying surface water and lacking symbiotic algae (which are found in their shallow-water counterparts), deep-sea corals show the same slow growth rates as many other deep-sea organisms. These slow growth rates are attributed to low nutrient availability and temperatures (Al-Horani et al. 2003). Because they are slow-growing and long-lived, deep-sea corals have a longevity that is relevant over geological timescales. This longevity and a banding pattern of skeletal growth are what allow the analyses of their skeletal components to provide important information about paleo-environmental archives and climate history (Roberts et al. 2006; Thresher et al. 2011). 

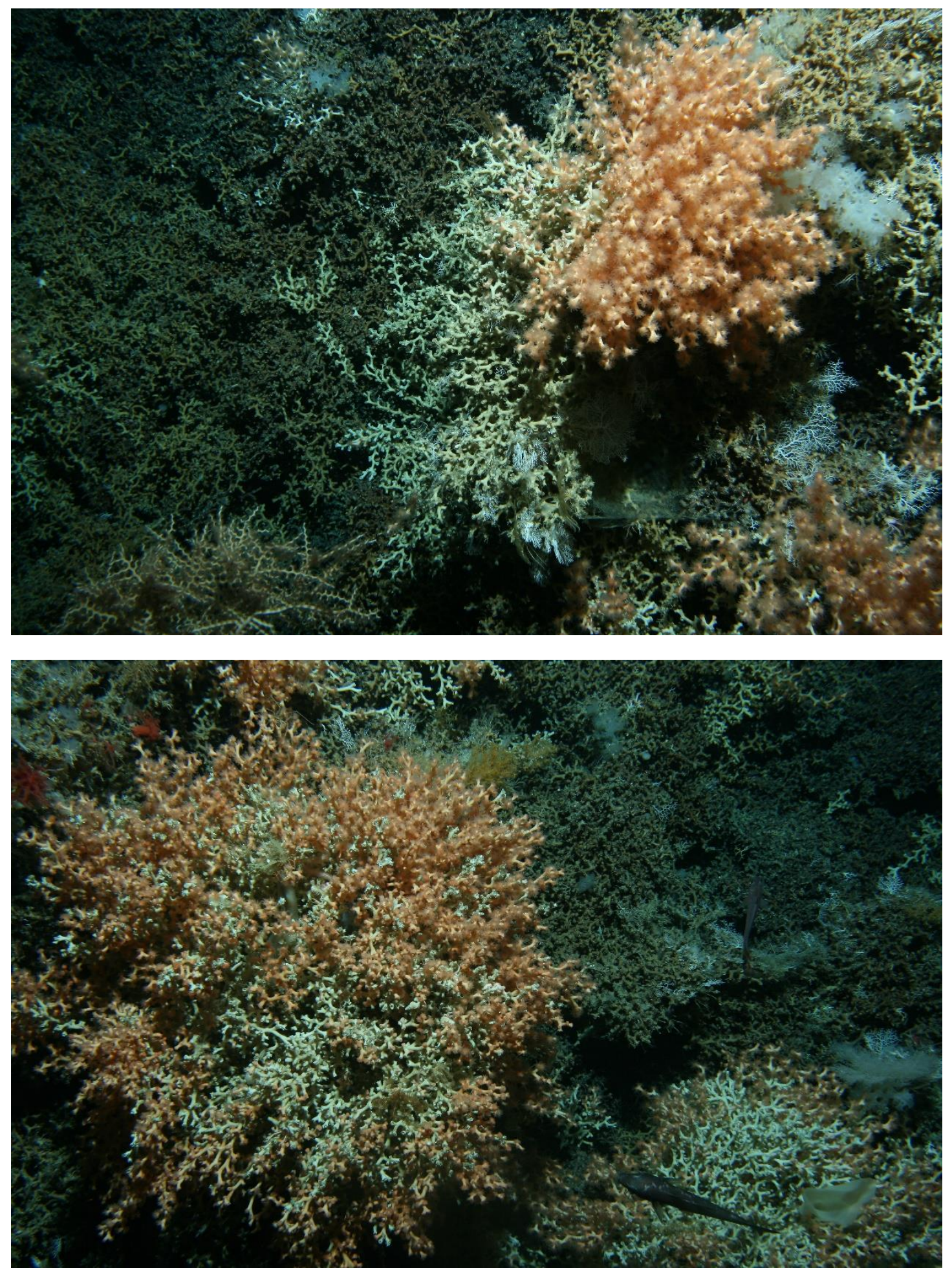

Figure 1.5: Live branching Solenosmilia variabilis corals in situ located on seamount features on the Chatham Rise within New Zealand's Exclusive Economic Zone: Polyps and extended tentacles are clearly visible in the top image (Image: NIWA). 


\section{How might deep-sea corals be affected by ocean acidification?}

As with other calcifying organisms, the depth of the ASH and $\mathrm{CSH}$ horizons place a strong control on the depth distribution of many habitat-forming corals. The majority of these corals within the Southwest Pacific region occur at intermediate depths (800-1200 m) and currently this is above the aragonite saturation horizon (Bostock et al. 2015). Due to OA, the ASH is expected to shoal to a depth which will place $28 \%$ of known deep-sea coral reefs in the Southwest Pacific region below the ASH (Bostock et al. 2015). Such an impact is not isolated to the Southwest Pacific. Globally, the ocean volume occupied by water which is saturated with aragonite - that is the volume of water above the ASH - is expected to decrease from $42 \%$ to $25 \%$ by the end of this century and these changes are expected to be concentrated in Polar waters (Steinacher et al. 2009). As discussed previously, the production of calcified material (calcification) below the ASH becomes more energetically expensive (Guinotte et al. 2006; Roberts et al. 2006); and currently, globally only 5\% of deep-sea corals are found below the ASH (Form \& Riebsell, 2012; but also see Bostock et al. 2015). Having a greater energy requirement for calcification is likely to impact all aspects of normal organism functioning, from respiration and metabolism, through to growth and calcification.

Benthic sessile organisms cannot retreat to shallower water and shoaling of the ASH will expose them to water that is under-saturated with aragonite. The projected loss of both deep-sea and cold-water corals due to OA is expected to be as high as $70 \%$ by 2100 (Orr et al. 2005). This loss is expected to occur even if attempts to reduce and mitigate the impacts of $\mathrm{CO}_{2}$ are successful because of the long timescales associated with the penetration of excess $\mathrm{CO}_{2}$ into the ocean (Cao et al. 2014). If saturation states of calcium carbonate fall low enough, coral skeletons may also start to dissolve (Kleypas et al. 1999; Rodolfo-Metalpa et al. 2010; Howard et al. 
2012).

However, not all corals show the same response to OA, and more research is required to understand these responses in the long-term and the mechanisms behind such responses. The deep-sea will be amongst the first marine environments to be exposed to the effects of ocean acidification and therefore it is important to understand: (1) how the organisms there will respond; (2) whether these responses are species-specific; and (3) whether there is capacity for acclimation or adaption. The physiological stress placed on corals, which are exposed to seawater with reduced $\mathrm{pH}$, can be gauged in a variety of ways, including: respiration and calcification rates (e.g. Maier et al. 2009; Form \& Riebsell, 2012; Lunden et al. 2014; Maier et al. 2013a, 2013b), polyp mortality, pHi and tissue loss. These responses will be considered in the succeeding section.

\section{Growth rate and calcification rate of deep-sea corals}

Corals are three-dimensionally complex and changes to the growth of corals can be observed through reductions in linear extension, as well as changes to skeleton porosity, microdensity and mineralogy. In some species of deep-sea corals, changes to calcification rates and skeletal micro-density and porosity are independent from changes to the $\mathrm{pH}$ of seawater (Maier et al. 2013a, 2013b; Movilla et al. 2013). Responses to OA are however, species-specific. For example, in the cosmopolitan species Madrepora oculata, Maier et al. (2011) found that those changes to seawater $\mathrm{pH}$ which are predicted to occur by the end of this century have no impact on calcification, but when the concentration of $\mathrm{CO}_{2}$ was reduced below present-day levels to pre-industrial levels, calcification rates significantly increased. This indicates that present-day calcification rates may have already significantly declined due to the atmospheric concentration 
of $\mathrm{CO}_{2}$ and associated changes to the chemistry of seawater. Other experiments show that calcification rate is affected by short-term exposure to reduced $\mathrm{pH}$ (e.g. Form \& Riebsell, 2012), but is unaffected or even enhanced by prolonged exposure; such results may demonstrate acclimatization. Form \& Riebsell (2012) investigated the response of a deep-sea coral, $L$. pertusa, to reduced $\mathrm{pH}$ conditions. When the $\mathrm{pH}$ of seawater was reduced by $0.1 \mathrm{pH}$ units relative to ambient levels, corals initially showed a reduction in calcification rates of between 26-29\% but prolonged exposure (six months) to the treatment caused the observed reductions in calcification rate to plateau and in some cases calcification rates increased relative to the control. Maier et al. (2009) conducted a similar experiment on the same species and also observed a plateau in the reduction of calcification rate after prolonged exposure to a reduced $\mathrm{pH}$ treatment.

While globally, less than $5 \%$ of habitat-forming deep-sea scleractinians have been recorded below the pre-industrial ASH (Guinotte et al. 2006), there is an increasing number being found below the ASH in the Southwest Pacific region (Bostock et al. 2015). This observation, coupled with research that shows deep-sea corals continuing to calcify and respire at normal rates under acidified and low aragonite conditions (Maier et al. 2013a. 2013b; Movilla et al. 2013), may suggest that scleractinian deep-sea corals have physiological mechanisms which allow them to calcify in under-saturated conditions.

The variation in response of different deep-sea corals, exposed to OA conditions, gives an indication of the variation in survivability that may be expected under projected conditions. There are several different factors that may help to predict how a species may respond to environmental change, including evolutionary history and phenotypic plasticity. Variation in responses are not limited to differences between species, but may also be observed between 
individuals belonging to the same species. Such within species variation could be explained by the age of an individual. Maier et al. (2009) determined that the extent of calcification reduction in response to $\mathrm{OA}$ is affected by the age of the coral and that a lowered $\mathrm{pH}$ reduces calcification more in young polyps than older polyps.

\section{Respiration rate of deep-sea corals}

Respiration rates can be used as an indicator of physiological stress and many calcifying marine invertebrates exhibit metabolic depression when exposed to OA (Michaelidis et al. 2005). This physiological response is cited as a strategy for enhancing survival under such conditions (Guppy \& Withers, 1999). Metabolic depression was observed in the coral L. pertusa which showed significantly reduced respiration rates, relative to a control, after 21 days of exposure to a reduced $\mathrm{pH}$ treatment (Hennige et al. 2014). Despite a reduction of respiration rates in the treatment group, calcification rates remained the same between both the treatment and control groups. The authors suggested that this decrease in respiration rate and maintenance of calcification would lead to an energetic imbalance and likely utilisation of lipid reserves. A similar response has been observed in some species of shallow-water zooxanthellate corals, where corals exposed to reduced $\mathrm{pH}$ lose coenosarc tissue that is rejuvenated when the corals are placed back into water of ambient $\mathrm{pH}$ (Kvitt et al. 2015). It is suggested that this response is caused by an energetic imbalance owing to the physiological stress of reduced seawater $\mathrm{pH}$, and as a response corals lose non-essential and energetically expensive tissue (Kvitt et al. 2015). 


\section{Intracellular pH (pHi) of deep-sea corals}

Intracellular $\mathrm{pH}(\mathrm{pHi})$ regulates many vital cellular processes such as cell signalling, enzyme activity, progression through the cell cycle, and protein synthesis (Madshus, 1988; Casey et al. 2010). The pHi of coral cells ranges from 7.13 to 7.41 (Venn et al. 2009) and must be kept between narrow limits for optimal cell function (Smith \& Raven, 1979). Many eukaryotic cells have evolved compartmentalised organelles which provide sites with specific $\mathrm{pH}$ conditions for different metabolic activities to occur (Casey et al. 2010). Disruptions to $\mathrm{pH}$ at the cellular level can lead to acidosis and changes to energy requirements which impact the energy balance of an organism (Pörtner et al. 2004; Fabry et al. 2008; Hofmann et al. 2013). Low pH conditions are expected as a result of $\mathrm{OA}$ and the ability of corals to regulate $\mathrm{pHi}$ is potentially affected under low pH conditions (Gibbin et al. 2014). While corals are adapted to narrow physiological limits and are sensitive to fluctuations of the surrounding environment, Gibbin et al. (2014) found that the photosynthetic activity of the endosymbiont in zooxanthellate corals provides the host cell with the ability to recover from $\mathrm{CO}_{2}$-driven acidification of seawater. Some deep-sea corals that have been exposed to reduced $\mathrm{pH}$ can up-regulate their internal $\mathrm{pH}$, so elevating the internal saturation state at the site of calcification (McCulloch et al. 2012). Whilst allowing for calcification below the ASH, this has a considerable energetic cost, which reduces the growth rate by $10 \%$ per $0.1 \mathrm{pH}$ unit reduction in ambient $\mathrm{pH}$ (McCulloch et al. 2012). These findings have implications for the fate of deep-sea coral reefs under future OA scenarios; their already extremely slow growth rates (Al-Horani et al. 2003; Fallon et al. 2014) may become slower. Deep-sea corals of course cannot host photosynthetic symbionts, and relatively little is understood about the mechanisms which allow them to up regulate $\mathrm{pHi}$. It is not yet understood whether they have the prolonged capacity to up-regulate $\mathrm{pHi}$ in response to OA conditions. 


\section{Phenotypic plasticity among deep-sea corals}

Ocean chemistry has not always favoured calcification and the paleoclimate record reveals that atmospheric $\mathrm{CO}_{2}$ levels have only been below 500 parts per million (ppm) for the last 24 million years (Pearson \& Palmer, 2000). Prior to this, atmospheric $\mathrm{CO}_{2}$ levels were much higher, resulting in a lower oceanic $\mathrm{pH}$ and saturation of aragonite (Pearson \& Palmer, 2000). As previously mentioned, under such conditions, basic homeostasis and biological processes (such as calcification) require more energy (Wood et al. 2008).

Many organisms, including some corals, show phenotypic plasticity (Todd, 2008; Kvitt et al. 2015). Phenotypic plasticity is described as changes in morphology which result from environmental change and can indicate an individual's ability to acclimatise to the environment (Todd, 2008). Some changes in morphology, as a result of environment-induced plasticity, allow energy to be diverted away from energetically expensive processes and the formation of non-essential tissues (Kvitt et al. 2015).

Researchers have found that several species of corals (Pocillopora damicornis, Oculina patagonica and Madracis pharencis) exhibit a breakdown of the coenosarc and loss of coloniality when the coral undergoes apoptosis due to exposure to reduced $\mathrm{pH}$ conditions (Fine \& Tchernov, 2007; Kvitt et al. 2015). A breakdown of the colonial form leads to an uncalcifying solitary polyp (Kvitt et al. 2015). This biological plasticity may be what allowed some stony corals to survive past periods of environmental change. 


\subsection{THE STUDY SPECIES: SOLENOSMILIA VARIABILIS}

Solenosmilia variabilis is an ecologically important deep-sea coral species found on seamounts throughout the Southwest Pacific region (Fig. 1.6; Tracey et al. 2011). This region is a hotspot for stony branching corals (Davies \& Guinotte, 2011), where they provide important habitat complexity in the deep-sea (Wheeler et al. 2007; Roberts et al. 2008). The importance of deepsea corals for providing habitat structure is evident in S. variabilis through colonial deformities which are caused by the burrowing of polychaete worms within the cavities of coral branches (Cairns, 1979). S. variabilis is typically found in large reef structures alongside other species of deep-sea corals, including the branching L. pertusa and M. oculata (Cairns, 1979). S. variabilis is a deep-sea coral less often referred to in the OA literature than more cosmopolitan species, such as the commonly used M. oculata (Maier et al. 2009, 2013a, 2013b). However, it is significant for a number of reasons. Firstly, it is found deeper than most other species of calcifying corals and in some cases below the ASH within the Southwest Pacific region (Bostock et al. 2015). Secondly, it is the dominant habitat-forming deep-sea coral in the Southwest Pacific region, including around New Zealand, and plays an important ecosystem role (Tracey et al. 2011). A review of protected deep-sea corals in the New Zealand region was undertaken by Consalvey et al. (2006) and coral protection in New Zealand was extended and clarified in 2010 as a result of this work. All stony corals in New Zealand are protected under the Wildlife Act 1953 (amendment 7A). With the exceptions of the Antarctic and North and Eastern Pacific basins, S. variabilis can be found globally (Cairns, 1995).

Solenosmilia variabilis has an aragonitic skeleton (Thresher et al. 2011; Bostock et al. 2015) and can be distinguished from other species of deep-sea corals by its equal dichotomous ' $\mathrm{v}$ ' 
shaped branching, which gives colonies a bushy appearance (Cairns, 1979). The calices (cupshaped depressions where the polyps sit) rarely exceed $5 \mathrm{~mm}$ in diameter (Cairns, 1979). It has a slow growth rate, having been measured as $0.51-0.77 \mathrm{~mm}$ per year, and its rate of net reef accumulation is just $0.27 \mathrm{~mm}$ (Fallon et al. 2014). The coenochyme is a pink/orange colour in this species. Bostock et al. (2015) surveyed the habitat of $S$. variabilis $(\mathrm{n}=326)$ in the Southwest Pacific region and $85 \%$ of occurrences were found at a depth of between $800 \mathrm{~m}$ and $1400 \mathrm{~m}$ where it appears to thrive (Fig. 1.6). 


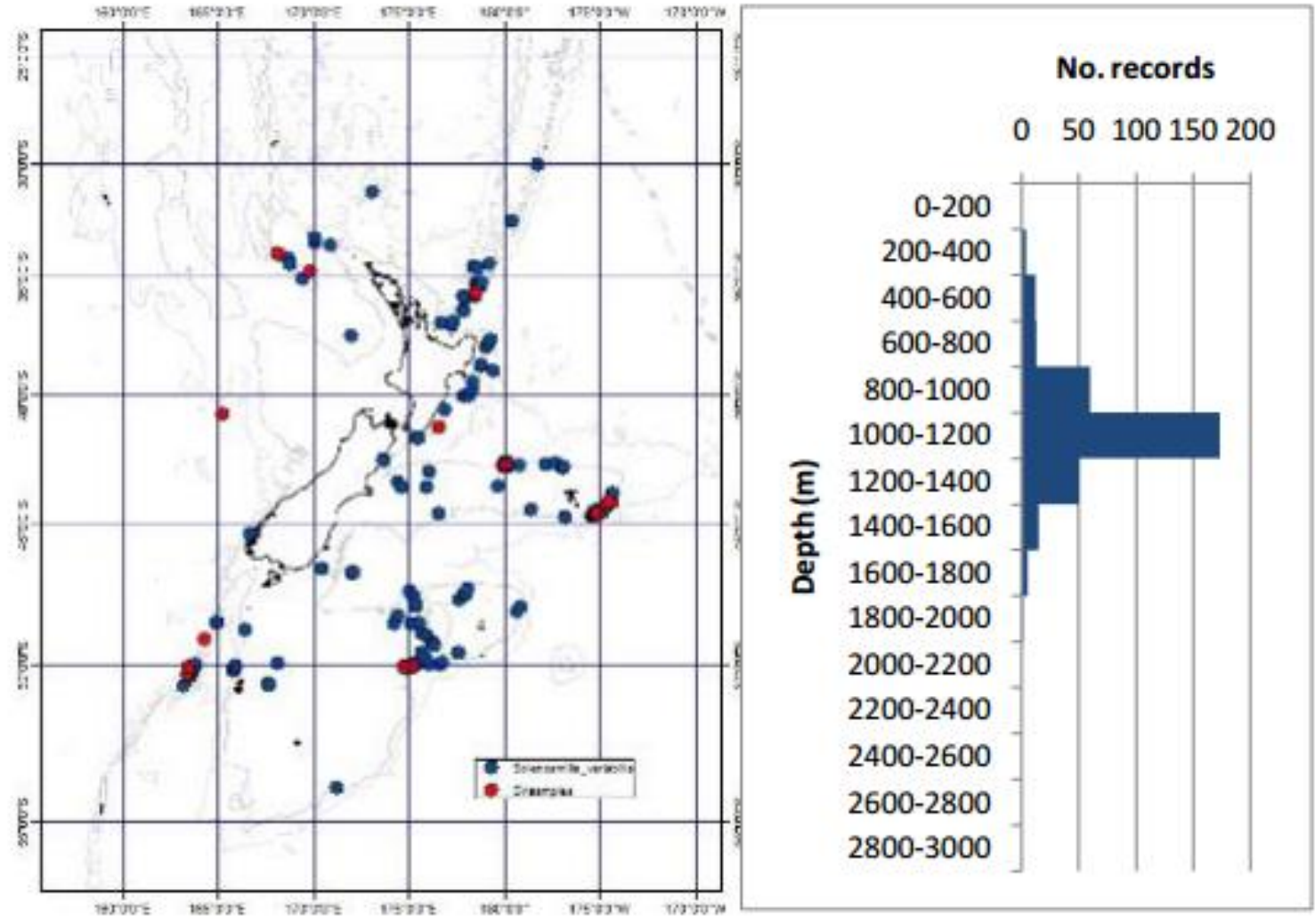

Figure 1.6: Distribution and depth data for Solenosmilia variabilis in the New Zealand region: The dots (left) show the locations within the New Zealand region from where $S$. variabilis samples have been obtained. The depth distribution (right) of S. variabilis is greatest between a depth range of $800-1200 \mathrm{~m}$. Source: Tracey et al. 2013).

The polyp size of $S$. variabilis has been reported as averaging $3.3 \pm 0.7 \mathrm{~mm}$ in diameter (Burgess, 2002). This is smaller than Enalopsammia rostrata $(5.35 \pm 0.9 \mathrm{~mm})$ but larger than Goniocorella dumosa $(2.74 \pm 0.4 \mathrm{~mm})$, both of which co-exist with $S$. variabilis reefs (Burgess, 2002). S. variabilis is a gonochoristic coral with broadcast spawning believed to be its mode of reproduction (Burgess, 2002). Fecundity of S. variabilis is high (>290 oocytes per polyp) (Burgess, 2002).

Within the Southwest Pacific region, S. variabilis has been identified as a species which may 
be able to tolerate a lower aragonite saturation level. Within this region, $20 \%$ of known $S$. variabilis populations are observed below the ASH, whilst $<3 \%$ of other stony branching corals have been observed below this horizon (Bostock et al. 2015). This suggests that S. variabilis may have mechanisms which enable it to calcify even when $\mathrm{pH}$ is reduced. The waters surrounding the continental shelf are not exempt from the effects of OA. These waters of the South Pacific are vulnerable to OA due to their proximity to the Southern Ocean, which has been identified as a large carbon sink (Feely et al. 2004).

\subsection{STUDY AIMS AND OBJECTIVES}

Research into the response of deep-sea corals is currently restricted to short-term experiments due to the difficulty associated with keeping them alive in aquaria (HERMIONE, 2012). It is well known that experiments in the laboratory cannot fully replicate the physical and biological variables observed in situ, particularly those observed in a deep-sea environment. Laboratory studies, however, are useful in characterizing responses to an environmental change, and can help quantify physiological stress; identifying thresholds of tolerance or mechanisms of resilience (Lunden et al. 2014).

The aim of this study was to determine the physiological response of deep-sea corals to ocean acidification, using $S$. variabilis as a study species. Physiological responses were determined by measurements of several key parameters, including growth rate (linear growth rate and buoyant weight), respiration rate, progressive loss of coenosarc tissue and $\mathrm{pHi}$. This study set out to answer the following three key questions:

1.) Does OA cause a decline in growth rate and a change in morphology in Solenosmilia variabilis? 
2.) Does OA induce signs of physiological stress in this coral?

3.) Does OA lower the pHi in this coral?

My working hypothesis was that the pHi of coral cells would decline with OA, while the coral's respiration rate would increase, perhaps to support increased energetic needs of calcification under acidified conditions. Due to a combination of physiological stress and a shift in the energy balance of $S$. variabilis colonies, it was expected that the growth rates of colonies in the treatment group would be less than those in the control group.

While the importance of deep-sea corals for deep-sea ecosystem functioning and habitat complexity is widely acknowledged (e.g. Almany, 2004; Roberts et al. 2006; Cairns, 2007), it is not yet understood how deep-sea organisms with a calcium carbonate structure may respond to ocean acidification. Due to shoaling of the $\mathrm{ASH}$, calcifying organisms of the deep-sea are predicted to be among the first to be adversely affected by ocean acidification. This research sets out to identify these responses in S. variabilis and to inform our understanding of the potential impacts of OA on deep-sea corals within the New Zealand region. 
2. Methods 


\subsection{AT-SEA SAMPLING OF SOLENOSMILIA VARIABILIS}

Corals were sampled using the NIWA seamount sled from RV Tangaroa. This epibenthic sled is an appropriate sampling tool for obtaining samples from rough and steep seabed regions particularly those adjacent to seamounts, and where deep-sea corals are typically found. The sled weighed $400 \mathrm{~kg}$ and consisted of a net encased in a steel frame (Fig. 2.1), which prevented samples within the net from being damaged whilst the gear was pulled along the seafloor. The width of the net opening was $1420 \mathrm{~mm}$. Gear was deployed off the vessel and once contact was made with the seafloor, it was towed at a speed of one knot. Once the gear was retrieved, a visual inspection was undertaken and any fragile biota, such as corals, were removed before depositing the sled contents onto the trawl deck for sorting (Fig. 2.1).

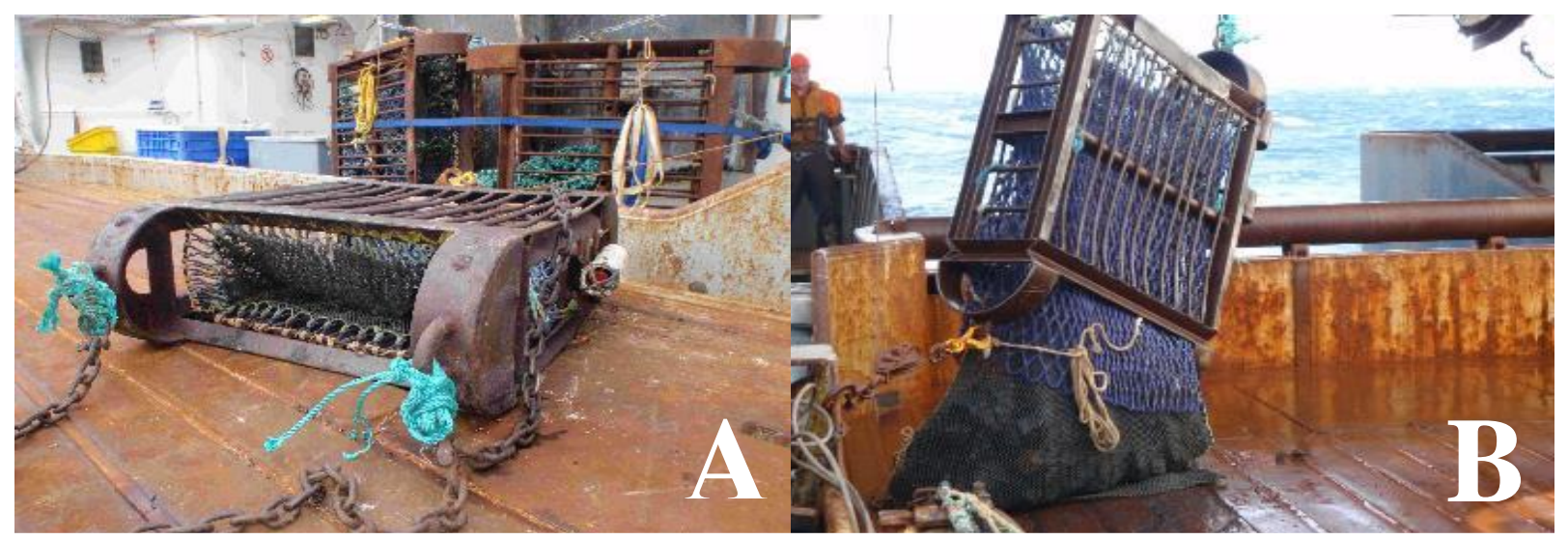

Figure 2.1: The National Institute of Water and Atmosphere (NIWA) seamount sled. This image shows the front end and protective bars on all sides (A) and emptying the sled contents on-deck (B). (Images: NIWA). 
Coral colonies used in this research were opportunistically sampled during the March 2014 Vulnerable Marine Ecosystem (VME) voyage (TAN1402) to the Louisville Ridge (Clark et al. 2015) (Fig. 2.2). For each of the 25 epibenthic sled tows carried out during the voyage, a chilled bin of seawater slurry (with an approximate temperature of $5.5^{\circ} \mathrm{C}$ ) was readied. This was so that corals collected by the sled could be placed as quickly as possible in seawater at a temperature similar to that of their natural habitat. The retained colonies were sampled at six stations from four seamounts along the Louisville Ridge region: Anvil, 39 South, Ghost, and Valerie (Fig. 2.2). Sampling depths at each station covered a wide bottom depth range (910 m to $1448 \mathrm{~m}$ deep; Table 2.1).

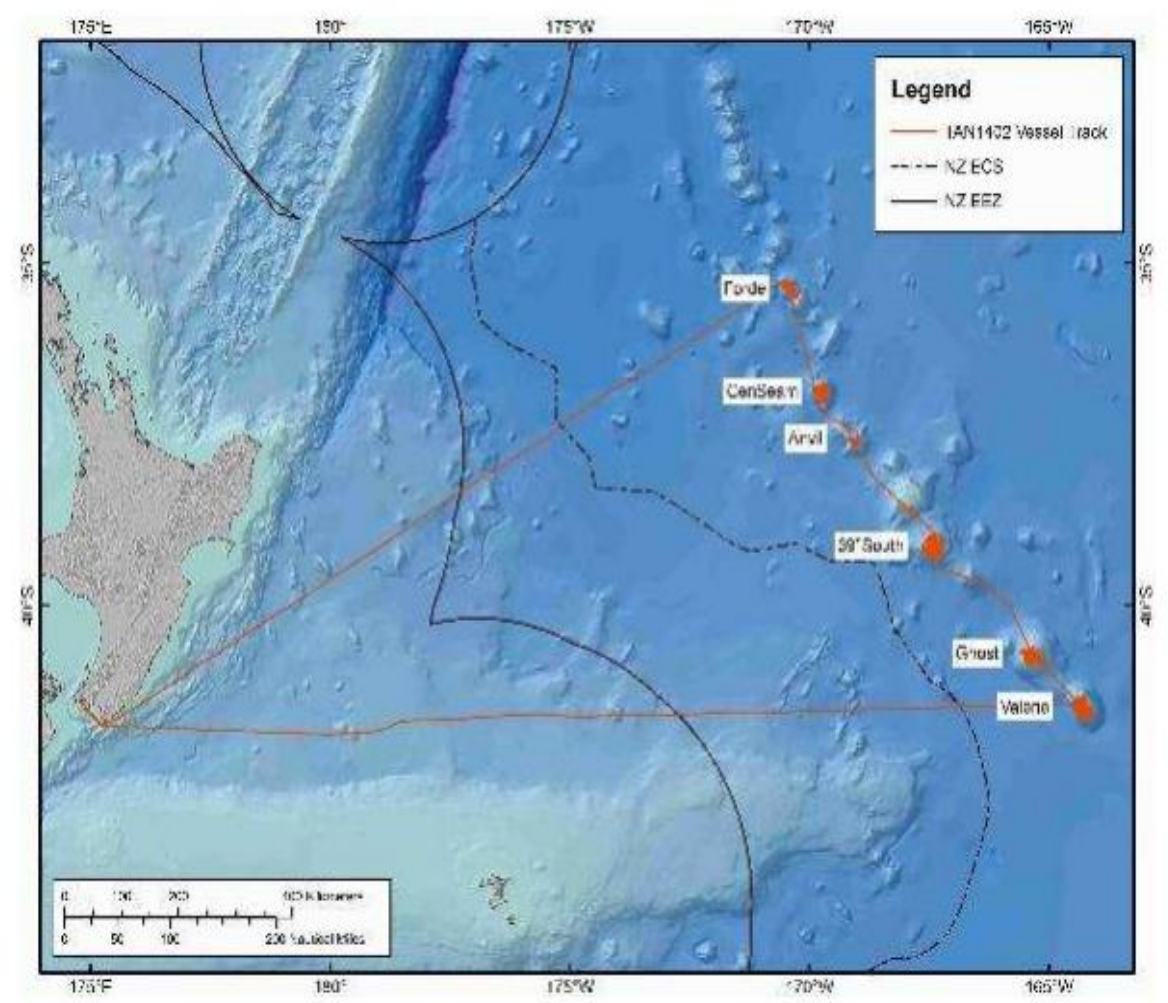

Figure 2.2: Track of RV Tangaroa during TAN1402 to the Louisville Seamount ridge, east of New Zealand. This map shows the chain of seamounts that were sampled using the epibenthic sled. Live coral colonies were successfully sampled from Anvil, 39 South, Valerie and Ghost seamounts (Source: Clark. et al. 2014). 
Upon collection, the slurry bins with live corals were taken to the vessel wet-lab for processing. Coral colonies of sufficient size (with the colony clump having an approximate volume greater than $20 \mathrm{~cm}^{3}$ and with over $75 \%$ of this colony volume consisting of live coral, indicated by live polyps) were then weighed, photographed, and labelled, before being placed into one of 12 bins in a flow-through, temperature-controlled aquarium system (Fig. 2.3). This system was set up with a high flow rate $\left(\sim 50\right.$ litres per hour) and a low temperature $\left(\sim 5^{\circ} \mathrm{C}\right)$, replicating the environmental conditions from where the corals were sampled. Throughout the voyage, the lids were lifted off the tanks infrequently, to ensure that the dark and low temperature environment was maintained. The corals were left to recover from the disturbance of collection and the barotrauma of being brought to the surface, and were not fed throughout the three-week voyage (it was assumed that they would obtain sufficient nutrients from un-filtered surface water, which was supplied via the flow-through aquarium). 


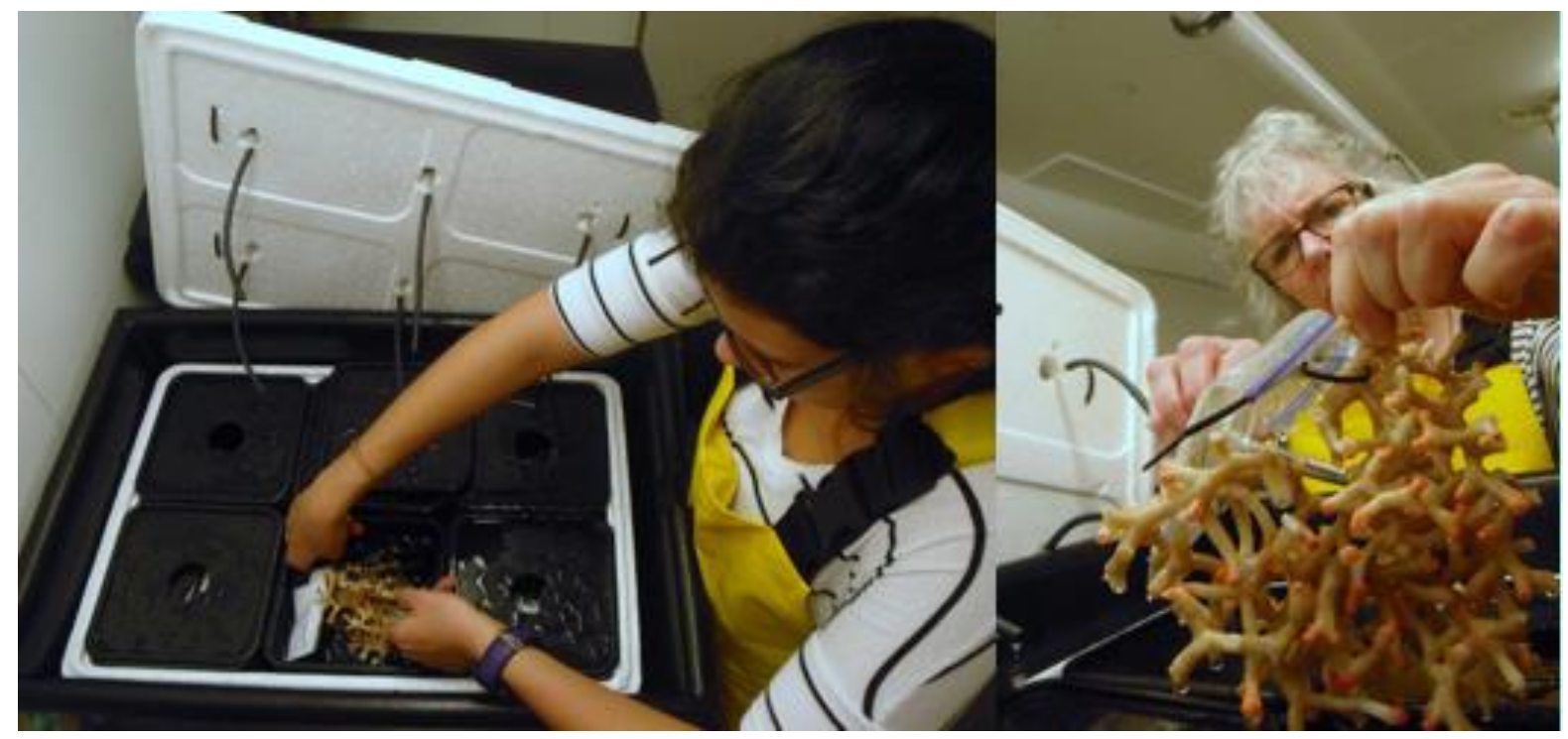

Figure 2.3: On-board aquarium where live Solenosmilia variabilis colonies were kept during the voyage. $S$. variabilis coral samples were kept in a low-light environment with the water temperature set at $\sim 5^{\circ} \mathrm{C}$ and a high water-flow rate (approximately 50 litres per hour). Corals were not fed whilst in this aquarium as it was assumed that they would receive enough nutrients from the un-filtered surface water which flowed directly into this aquarium. (Images: NIWA).

Conductivity, Temperature and Depth (CTD) casts (Seabird 911: Seattle, WA, USA) were conducted at sampling sites (Table 2.1) to determine natural environmental parameters. This CTD measured pressure (depth), temperature, conductivity (salinity) and dissolved oxygen. Table 2.2 shows the water chemistry at these sites. Upon arrival back on-shore, live corals were transferred to NIWA's Mahanga Bay containment facility. CTD casts and in situ water sampling conducted at each collection site determined the physical conditions from where corals were sampled (Table 2.2), and the aquarium system was continuously calibrated to reflect these parameters. Corals were initially held at a water temperature of $\sim 5^{\circ} \mathrm{C}$ and a flow rate of $50 \mathrm{~mL}$ per minute in the dark, and were fed twice weekly with a $3 \mathrm{~mL}$ mixture consisting of $10 \%$ commercial coral food (JBL Koralfluid. Neuhofen, Germany) which was supplemented with 
10\% commercial shellfish diet (Instant algae marine microalgae concentrates: larval shellfish diet 1800. California, United States) and diluted to the required volume with $1 \mu \mathrm{m}$ FSW.

\section{Table 2.1. A summary of the seamounts that were successfully sampled for live coral} colonies using the epibenthic sled. The Table gives the latitude and longitude of sampling stations, as well as the start depth and end depth of each station. Note that the Valerie seamount was sampled, and live coral colonies successfully obtained, on two separate occasions. (See Tracey et al. 2014 for a full description of CTD deployment and data analysis).

\begin{tabular}{l|l|l|l|l}
\hline \hline Seamount & Latitude (S) & Longitude (W) & Sampling & Sampling \\
& & & start depth (m) & finish depth (m) \\
\hline \hline Anvil & $37^{\circ} 42.44^{\prime}$ & $169^{\circ} 0.9^{\prime}$ & 1244 & 1370 \\
\hline Valerie & $41^{\circ} 34.89^{\prime}$ & $164^{\circ} 15.31^{\prime}$ & 1223 & 1241 \\
\hline Valerie & $41^{\circ} 21.88^{\prime}$ & $164^{\circ} 25.14^{\prime}$ & 1220 & 1250
\end{tabular}


Table 2.2: A summary of water properties at the sample sites. Values shown are depth range (meters), bottom temperature $\left({ }^{\circ} \mathrm{C}\right)$ and bottom dissolved oxygen concentration $(\mathrm{mL} / \mathrm{L})$.

\begin{tabular}{l|l|l|l}
\hline \hline Seamount & Depth range $(\mathbf{m})$ & Bottom Temperature $\left({ }^{\circ} \mathbf{C}\right)$ & Bottom DO $(\mathbf{m L} / \mathbf{L})$ \\
\hline \hline Anvil & $10-1408$ & 3.42 & 3.55 \\
\hline 39 South & $10-1972$ & 2.50 & 3.10 \\
\hline Ghost & $10-1471$ & 3.25 & 3.61 \\
\hline Valerie & $11-1489$ & 3.30 & 3.50
\end{tabular}

\subsection{THE OCEAN ACIDIFICATION FACILITY}

Three months after the initial transfer of corals to the Mahanga Bay containment facility, corals were transferred to NIWA's Ocean Acidification and Antarctic Research Facility (hereafter referred to as 'The OA Facility') at Greta Point, Wellington (Fig. 2.4). While in the OA Facility, corals were held in continuous flow-through tanks with a high flow rate $(\sim 130 \mathrm{~mL}$ per $\mathrm{min})$ and a temperature of $\sim 3.5^{\circ} \mathrm{C}$. This high flow rate meant that it took approximately $30 \mathrm{~min}$ for the water within each 4-L tank to be replaced. Corals were maintained in this new experimental set-up for three months before experimental treatment began. This allowed complete acclimation to laboratory conditions and ensured that all colonies had the same nutritional conditions. 


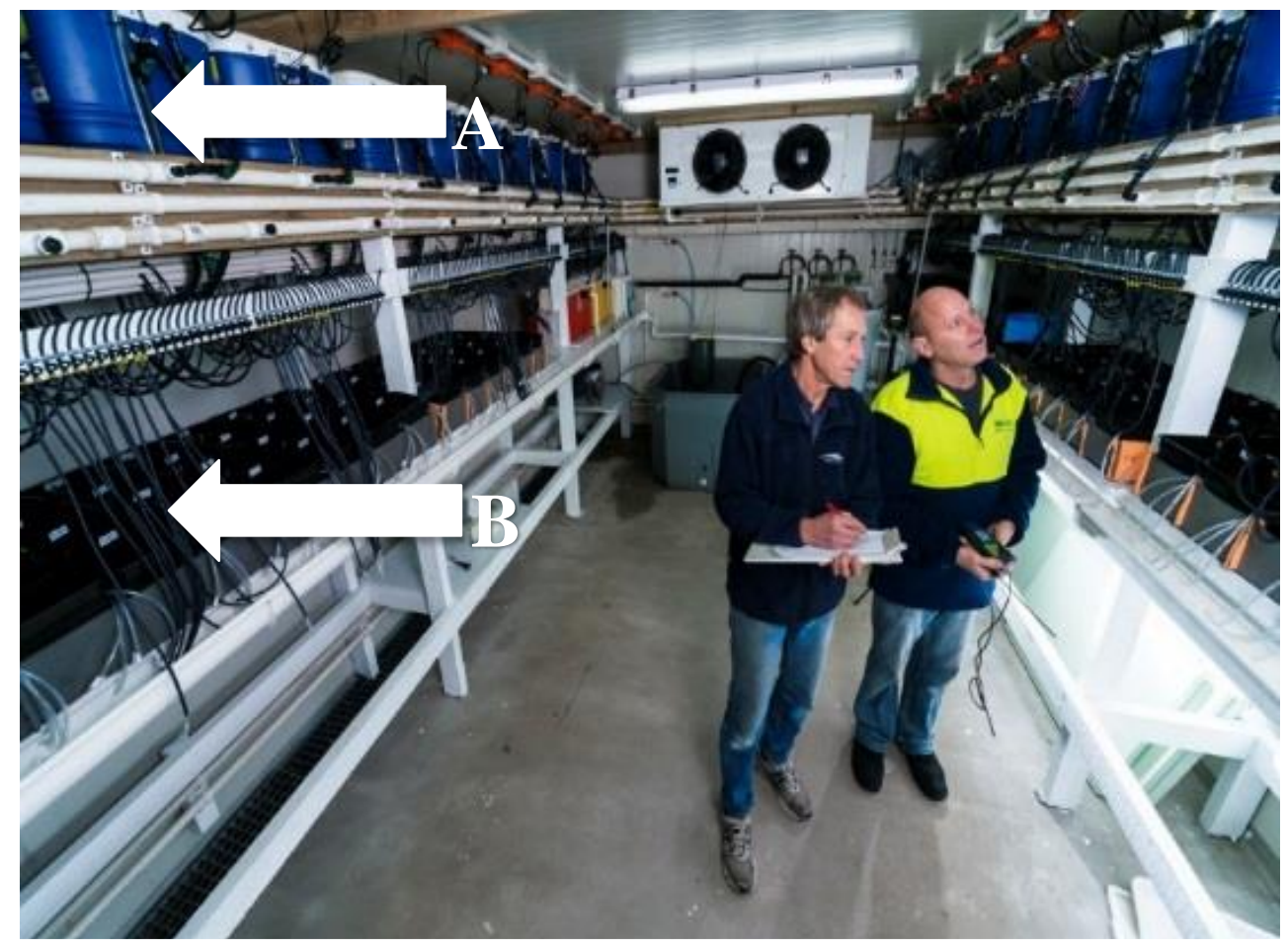

Figure 2.4: The Ocean Acidification Facility at NIWA's Greta Point. Shown are the header tanks where treatment values were adjusted (A) and the holding tanks (B) where coral fragments were kept (Image: NIWA).

Colony fragments were held in 4-L tanks within the OA Facility at NIWA, Greta Point (Wellington) for the duration of the experiment. A total of 18 tanks were used and within each tank there were three coral fragments. Two header tanks were used for the experiment (treatment and control). Filtered seawater (FSW) from Evans Bay, Wellington Harbour, was chilled to experimental levels and fed to separate header tanks. Treatment water was adjusted in each header tank before being fed to the experimental tanks at $150 \mathrm{~mL} \mathrm{~min}^{-1}$ in a flow-through system. Both temperature and $\mathrm{pH}$ were directly controlled by Jumo dTrans $\mathrm{pH} 02$ industrial controllers with both remote control and monitoring functions from a LabView server, and 
communications via a MODBUS serial interface. Controller inputs (analogue) from each experimental header tank were achieved by a precision PT100 temperature probe and Sensorex S150C $\mathrm{pH}$ probe. The adjustment of seawater $\mathrm{pH}$ in each header tank was achieved by diffusion of gaseous $\mathrm{CO}_{2}$ gas through thin-walled silicone tubing (BioChem Fluidics, 100P3MP24-02S). Water was circulated in each header tank with a pump, and the temperature and $\mathrm{pH}$ of the header tanks was constantly logged using $\mathrm{pH}$ and temperature probes, and monitored by the system. The $\mathrm{pH}$ probes in each header tank were calibrated fortnightly with TRIS and AMP buffers. This automated OA facility, and its development, is detailed in McGraw et al. (2010).

\subsection{THE EXPERIMENT: EXPOSURE OF SAMPLES TO HIGH $\mathrm{pCO}_{2}$}

Partial pressure is the pressure that a particular gas exerts in a solution. Partial pressure of carbon dioxide $\left(\mathrm{pCO}_{2}\right)$ is a measure of the amount of carbon dioxide in a solution,. Solutions with a higher partial pressure have a higher quantity of carbon dioxide. This experiment consisted of a control and treatment group. Corals in the control group were exposed to an ambient treatment of $\mathrm{pCO}_{2}(519 \mathrm{ppm})$ and $\mathrm{pH} 7.88$, which reflected the seawater chemistry at the sites from which the corals were sampled (Tables $1 \& 2$ ). In comparison, treatment corals were exposed to a high $\mathrm{pCO}_{2}(920 \mathrm{ppm})$ corresponding to a $\mathrm{pH}$ of 7.65 ; this reduced $\mathrm{pH}$ was based on projected changes to seawater $\mathrm{pH}$ through to 2100 (IPCC, 2013; Orr et al. 2005). Furthermore, under the high $\mathrm{CO}_{2}$ RCP8.5 scenario (IPCC, 2013), $\mathrm{pH}$ reductions of $>0.2-0.3 \mathrm{pH}$ units from current levels are expected in $23 \%$ of deep-sea canyons and on $8 \%$ of seamounts, where corals are typically found, by 2100 (Gehlen et al. 2014), giving the experimental conditions of this research some context. Four water samples (two from separate treatment tanks and two from separate control tanks) 
were taken on two different occasions (approximately six months apart) during the experiment, and analysed for water chemistry (Table 2.3).

Table 2.3: Tank conditions during the experiment. Two water samples (one from each of the treatment and control tanks) were taken on two separate occasions. Water samples were analysed for total alkalinity (TA), dissolved inorganic carbon (DIC), and aragonite and carbonate saturation states $(\Omega \operatorname{Ar}$ and $\Omega$ Ca, respectively). Temperature was recorded by continuous data loggers in two of the 18 experimental tanks (one treatment and one control tank) and $\mathrm{pH}$ was calculated using these variables.

\begin{tabular}{|c|c|c|c|c|c|c|}
\hline $\begin{array}{l}\text { Treatment } \\
\text { (target) }\end{array}$ & $\begin{array}{l}\text { Temperature } \\
\left({ }^{\circ} \mathbf{C}\right)\end{array}$ & $\begin{array}{l}\text { pH } \\
\text { (calculated) }\end{array}$ & $\begin{array}{l}\text { TA } \\
(\mu \text { mol kg-1) }\end{array}$ & DIC & $\boldsymbol{\Omega} \mathbf{A r}$ & $\Omega \mathbf{C a}$ \\
\hline $\begin{array}{l}\mathrm{pH} 7.65 \\
\text { (treatment) }\end{array}$ & $\begin{array}{l}3.446 \\
\pm 0.004\end{array}$ & $\begin{array}{l}7.713 \\
\pm 0.124\end{array}$ & $\begin{array}{r}2260 \\
\pm 53\end{array}$ & $\begin{array}{l}2229.600 \\
\pm 89.844\end{array}$ & $\begin{array}{l}0.78 \\
\pm 0.19\end{array}$ & $\begin{array}{l}1.24 \\
\pm 0.30\end{array}$ \\
\hline $\begin{array}{l}\mathrm{pH} 7.88 \\
\text { (control) }\end{array}$ & $\begin{array}{l}3.381 \\
\pm 0.003\end{array}$ & $\begin{array}{l}7.794 \\
\pm 0.142\end{array}$ & $\begin{array}{r}2257 \\
\pm 56\end{array}$ & $\begin{array}{l}2202.515 \\
\pm 13.106\end{array}$ & $\begin{array}{l}0.93 \\
\pm 0.31\end{array}$ & $\begin{array}{l}1.48 \\
\pm 0.49\end{array}$ \\
\hline
\end{tabular}

\subsubsection{Assigning of samples to a treatment or control}

Coral colonies sampled from Anvil and Valerie seamounts were selected for the experiment due to the similar depth and seawater chemistry parameters of these sites (Tables $2.1 \& 2.2$ ). Coral colonies (one from Anvil seamount and two from Valerie seamount) were carefully broken using a pair of nose pliers, to achieve 54 colony pieces in total. Each colony piece $(\sim 4-6 \mathrm{~cm}$ in 
length) was then attached to a small piece of plastic mesh along with a label to allow identification of its origin (Fig. 2.5).

The experimental set-up consisted of 18 tanks, each with three coral fragments per tank. Tanks 1-9 were assigned as control tanks and tanks 10-18 were assigned as treatment tanks. The tanks were identical, to avoid any tank bias. Fragments from individual colonies were randomly placed among the 18 tanks. The $\mathrm{pH}$ in the treatment tanks was reduced over three days until it reached the treatment value. This experiment ran over the course of 12 months.

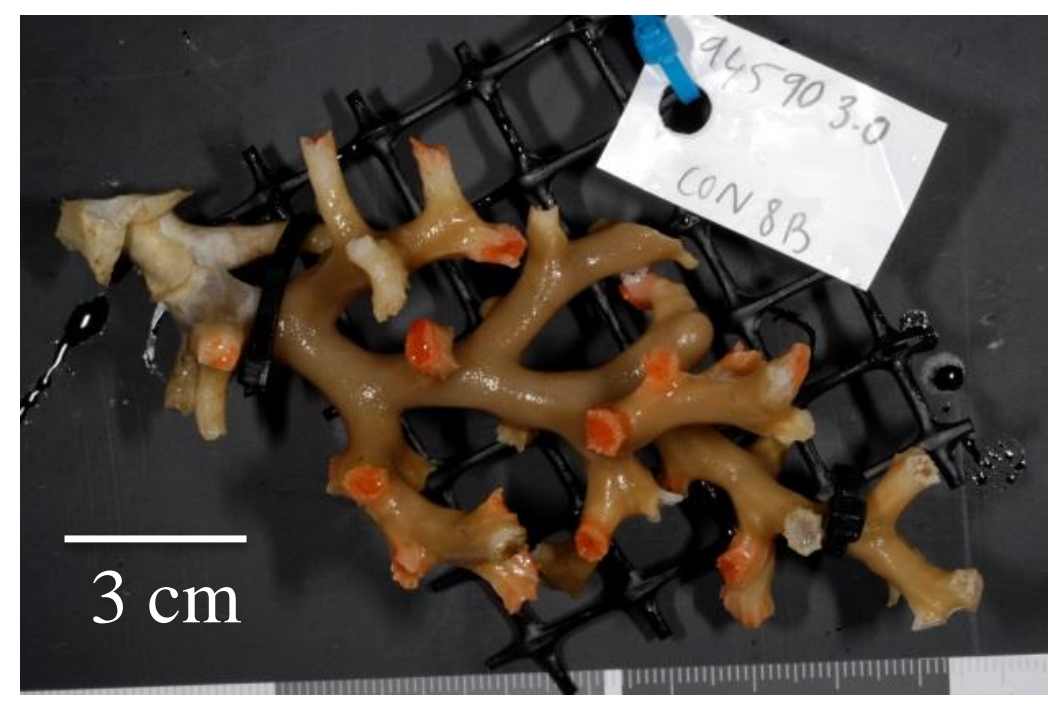

Figure 2.5: Image of a live Solenosmilia variabilis fragment used in this experiment. Annotated on the label is a unique ID which can be used to identify the seamount and station data from where the coral was sampled.

\subsubsection{Experimental timeline}

The experimental time-line can be broken down into both major and intermediate sampling points. Intermediate sampling points occurred at bi-monthly intervals throughout the experiment, and at each, measurements of buoyant weight, linear growth rate and live polyp count were taken. Major sampling points occurred after 6 and 12 months of exposure, with 
measurements of respiration, and after 9 and 12 months exposure with measurements of pHi (Fig. 2.6). The experiment was set up on 29 th July 2014 , when coral colonies were divided into multiple fragments, and began on 18th September 2014, when the $\mathrm{pH}$ of water flowing to the treatment tanks was incrementally reduced over three days. Feeding continued throughout the experiment, with the same concentration, rate and food type as outlined earlier. 


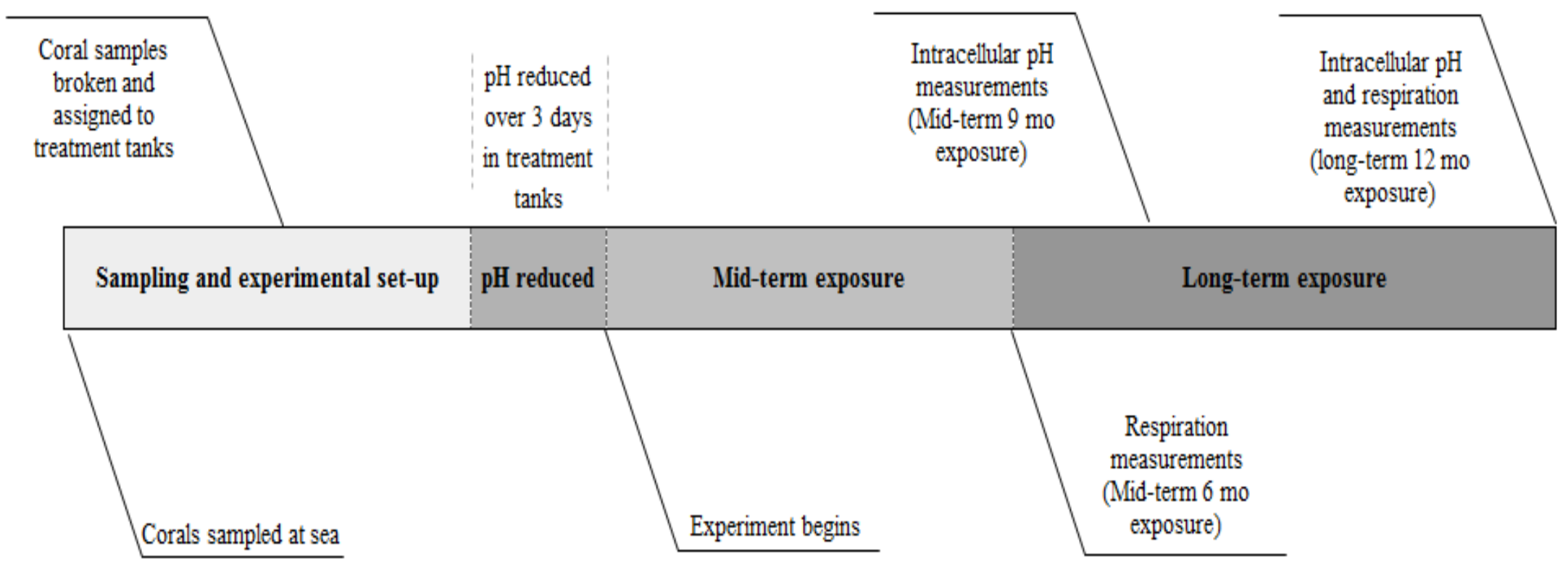

Figure 2.6: A schematic diagram of the experimental timeline. Respiration measurements were taken for corals after both midterm (6 months) and long-term exposure (12 months) to the reduced $\mathrm{pH}$ treatment. Measurements of the intracellular $\mathrm{pH}(\mathrm{pHi})$ of coral cells were taken after mid- to long-term (9 months) and long-term exposure (12 months) to the reduced pH treatment. Intermediate sampling (photography, polyp count and buoyant weight) was carried out every two months for the duration of the experiment. The same measurements for all sampling points were also undertaken in corals of the control group at the same time points. 


\subsection{QUANTIFYING GROWTH, MORPHOLOGY AND HEALTH}

At each intermediate sampling point (every two months), weight, morphology and the number of live polyps on each coral fragment were quantified. The number of live polyps was quantified with a simple visual count.

\subsubsection{Buoyant weight}

The buoyant weight of each coral fragment was measured using a three-point decimal place calibrated balance every two months ( $\mathrm{n}=18$, for each of the control and treatment). The change in weight, calculated as the total percentage remaining of the initial weight, was then calculated using the following equation:

$$
100-\left(\frac{\left(B W_{1}-B W_{J}\right)}{\left(B W_{1}\right)}\right) \times 100
$$

Where $B W_{1}$ is the buoyant weight taken at the first time point and $B W_{J}$ is the buoyant weight at each of the subsequent time points (i.e. no change in buoyant weight yielded a value which was $100 \%$ of the initial weight, values less than 100 indicate a decrease in buoyant weight and values greater than 100 indicate an increase in buoyant weight).

Buoyant weights were taken with the plastic mesh, cable ties and labels attached, as these were required for measurements of linear growth. At the end of the experiment, labels, mesh and cable ties were removed from each fragment and buoyant weighed, and the coral fragment buoyant weights throughout the experiment adjusted accordingly. 


\subsubsection{Linear growth}

Each coral fragment was attached with cable ties to a piece of plastic mesh, to ensure that it remained in the same orientation throughout this experiment. Photographs of each fragment were taken at bi-monthly intervals. From these photographs, linear growth was determined by selecting a fixed point on the coral (an easily identifiable feature, such as a branching point or growth feature) and measuring from this point to the point just below a polyp where calcification occurs and along the axis of growth. The measurements were taken from each photo in the imaging software ImageJ $\odot$. Where possible a maximum of four such measurements were taken on each fragment.

For the analysis of linear growth rate, an individual growth rate was calculated for each coral fragment remaining in both the control and treatment groups at the end of the experiment $(n=$ 18 for each of the treatment and control groups). For those fragments where the growth rate of more than one individual branchlet could be measured, a single branchlet measuring $2-5 \mathrm{~cm}$ in length was used; this length was chosen as all colonies had at least one branchlet of this size. 

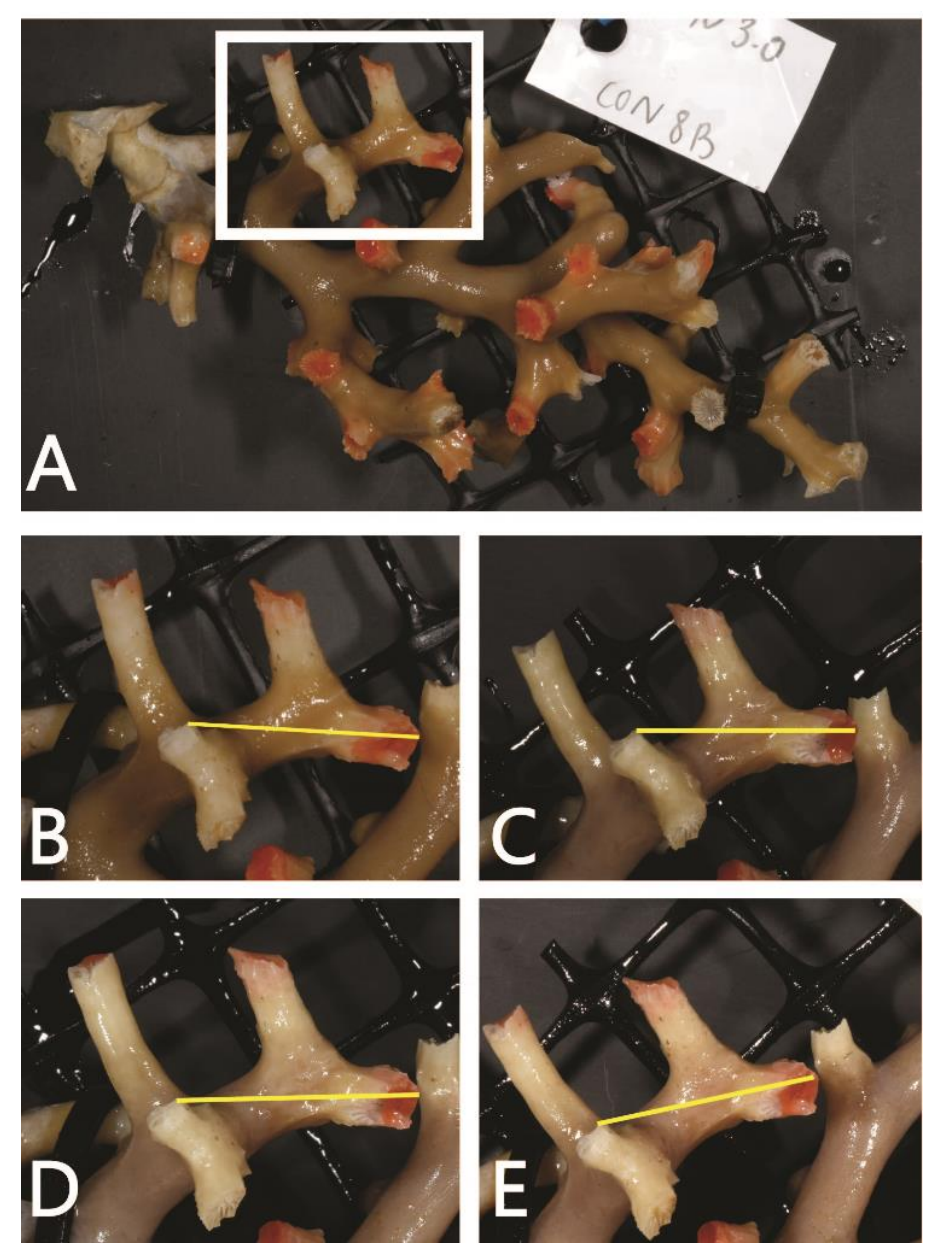

Figure 2.7. Images of a Solenosmilia variabilis colony fragment taken at bimonthly intervals. These images show an entire coral fragment with the area-ofinterest highlighted (A) and images taken on successive sampling occasions (B-D), showing the measurement axis. (Images: NIWA).

\subsubsection{Polyp mortality}

Polyp mortality for each coral sample was analysed every two months through a visual count of the number of live polyps $(n=18$ coral fragments, for each of the control and treatment $)$. The total percentage remaining of this initial polyp count at each time point was then calculated using the following equation: 


$$
100-\left[\left(\frac{\left(P_{1}-P_{J}\right)}{\left(P_{1}\right)}\right) \times 100\right]
$$

Where $P_{1}$ is the polyp count taken at the first time point and $P_{J}$ is the polyp count at each of the subsequent time points (i.e. no change in polyp count yielded a value which was $100 \%$ of the initial count, values less than 100 indicate a decrease in polyp count and values greater than 100 indicate an increase in polyp count).

\subsubsection{Loss of coenosarc}

It was noted throughout the experiment that coral colonies showed a visible loss of colour, consistent with a loss of tissue from their surface. Images taken during this research, and used for the measurement of linear growth rates, were analysed for this progressive loss in colour saturation, which was assumed to be a loss of coenosarc (M. V. Kitahara, University of São Paulo, personal communication). Methods used to measure this loss of colour were based on that of Winters et al. (2009).

Images were first cropped to remove the background and then profiled using the colour histogram plugin on the imaging software, ImageJ. The colour histogram plugin produces a colour profile for each image. This profile gives a mean value of intensity for each of the colour channels ranging between 0 and 255, representing the brightness of each channel. The relative intensity for each channel was then calculated using the following equations: 


$$
\begin{gathered}
T=R+G+B \\
R_{r}=\frac{R}{T} \\
G_{r}=\frac{G}{T} \\
B_{r}=\frac{B}{T}
\end{gathered}
$$

Where $\mathrm{T}=$ the total intensity of an image, $\mathrm{R}=$ mean intensity of the red channel, $\mathrm{G}=$ mean intensity of the green channel, $B=$ mean intensity of the blue channel, $R_{r}=$ relative intensity of the red channel, $G_{r}=$ relative intensity of the green channel and $B_{r}=$ relative intensity of the blue channel. Calculating the percentage of relative brightness for each channel, rather than using the mean value of brightness for each channel, supresses the influence that any changes in illumination, exposure or internal camera processing may be having on the brightness of each channel (Richardson et al. 2009).

A pilot study was first conducted, where coral colonies from the treatment group $(n=4)$, with a visible loss in coenosarc saturation over time, were profiled for colour intensity. Intensity of the green channel remained consistent over time, while intensity of the red channel decreased and intensity of the blue channel increased (Fig. 2.8).

To confirm that the visual loss in health corresponded to changes in the relative intensity of the blue and red colour channels, photos taken of the same four corals were then visually categorized on a scale from one to five. Corals in Category Five were the most healthy, showing pink or brown pigmentation on the skeleton and bright polyps. A coral in Category One was dead, with no pink or brown pigmentation. The percentage loss for each of these channels was 
then plotted against the health index assigned to that coral (Fig. 2.9). A decrease in relative intensity of the red channel corresponded to a reduction in coral health, whilst an increase in the relative intensity of the blue channel corresponded to a reduction in coral health. There appeared to be no relationship with the green colour channel.

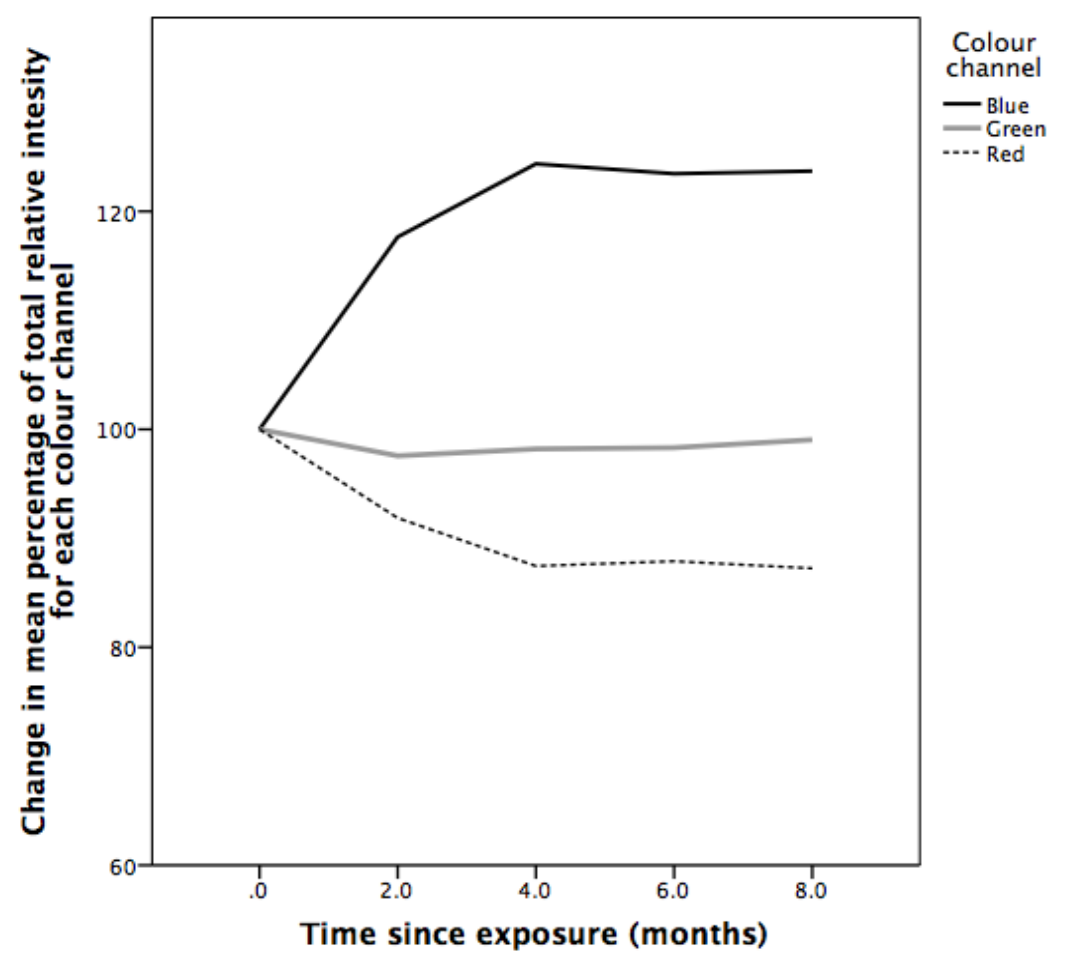

Figure 2.8: The relative change in intensity of each of the red, green and blue (RGB) colour channels in images of Solenosmilia variabilis colony fragments, taken over 12 months. A pilot study ( $\mathrm{n}=4$ ) was conducted to determine how the relative intensity of each of the RGB colour channels changed over time.

Once is it was confirmed that a loss in intensity of the red colour channel corresponded to a loss in coral health (Fig. 2.8 - 2.9), images were analysed for percentage change in relative intensity of the red colour channel using the following equation: 


$$
\mathrm{R}_{\mathrm{J}}=100 \times \frac{\left(\mathrm{S}_{\mathrm{J} 1}-\mathrm{S}_{\mathrm{J} 2}\right)}{\left(\mathrm{S}_{\mathrm{J} 1} \times \frac{\mathrm{T}_{1}}{\mathrm{~T}_{2}}\right)}
$$

Where $\mathrm{R}_{\mathrm{J}}=$ the relative intensity of the $\mathrm{J}^{\text {th }}$ colour channel (red, green or blue), $\mathrm{S}_{\mathrm{J} 1}=$ the mean intensity of the $\mathrm{J}^{\text {th }}$ colour channel at time-point one, $\mathrm{S}_{\mathrm{J} 2}=$ the mean intensity of the $\mathrm{J}^{\text {th }}$ colour intensity at time-point two, $\mathrm{T}_{1}=$ time-point one and $\mathrm{T}_{2}=$ time-point two. 

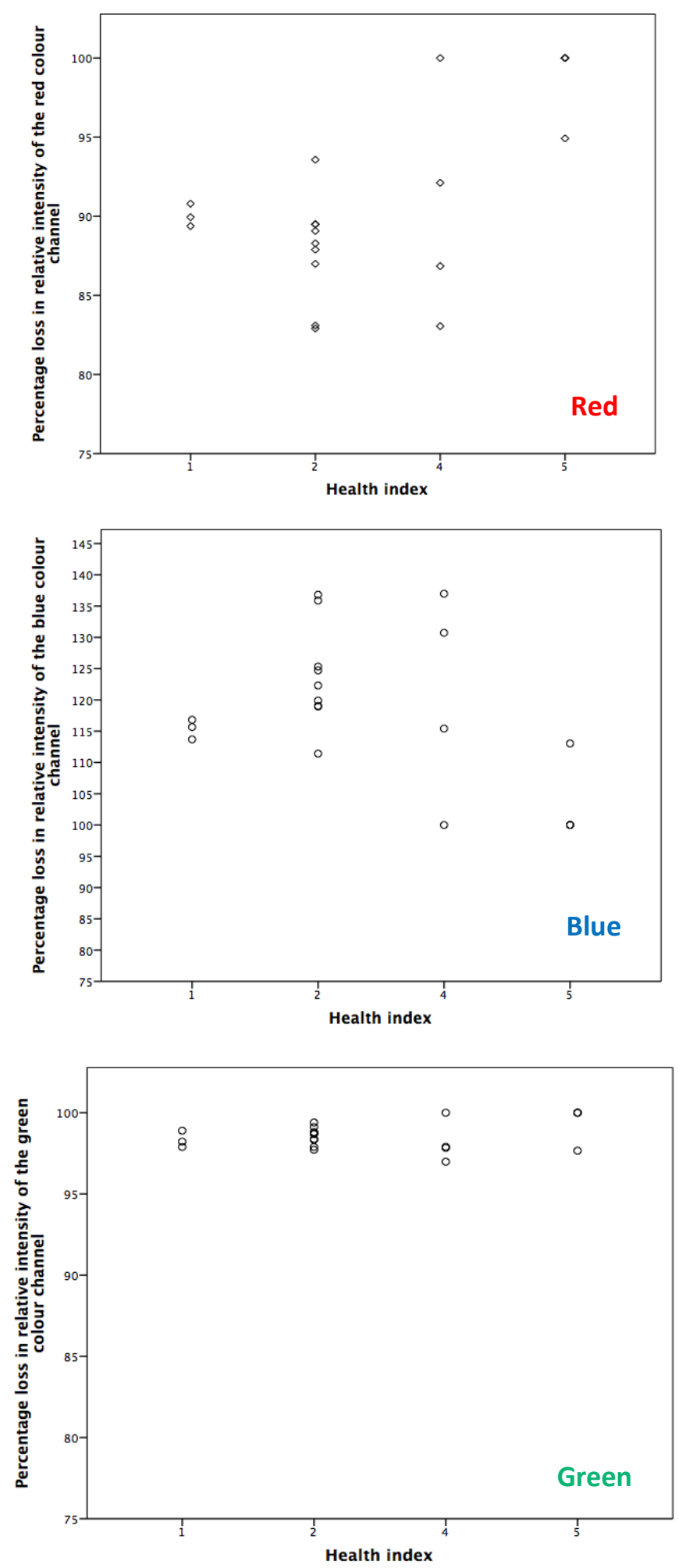

Figure 2.9: The relationship between coral health index of Solenosmilia variabilis fragments and the relative loss in intensity of each of the red, blue and green colour channels. These plots were used to confirm a loss in intensity of the red colour channel corresponded to a visual loss in coral health and coenosarc. 


\subsubsection{Respiration rate}

At 6 and 12 months into the experiment, samples were selected at random from the treatment and control groups ( $\mathrm{n}=9$, for each of treatment and control), and the respiration rate of these samples measured. Measurements were carried out in an enclosed, variable-volume $500 \mathrm{~mL}$ chamber (Fig. $2.10-2.11$ ), where oxygen $\left(\mathrm{O}_{2}\right)$ consumption was measured through the depletion of $\mathrm{O}_{2}$. Each chamber was equipped with a magnetic stirrer to ensure homogeneity of $\mathrm{O}_{2}$ around the coral fragments (Fig. 2.11). Within each sealed lid was a hole, sealed with an oring and through which small glass vials were pushed so that the bottom of each vial made contact with seawater in the chamber (Fig. 2.11); glued to the base of each glass vial was a Presens Pst $3 \mathrm{O}_{2}$ sensor. This set-up provided the $\mathrm{O}_{2}$ sensor with access to the chamber without altering the $\mathrm{O}_{2}$ concentration in the chamber. The $\mathrm{O}_{2}$ sensor was two-point calibrated each day the chambers were used, using $0 \%$ and $100 \%$ saturated seawater. The $0 \%$ saturated seawater was obtained by dissolving $1 \mathrm{~g}$ of sodium sulphite (Sigma-Aldrich) in seawater and the $100 \%$ was obtained by bubbling air through seawater for $30 \mathrm{~min}$ prior to calibration. Individual coral fragments were left in chambers for a minimum of 20 min to settle before airtight lids were attached and any $\mathrm{O}_{2}$ bubbles removed. Each chamber was placed in a waterbath set to $3.5^{\circ} \mathrm{C}$ and kept in darkness for the duration of the measurements.

Total $\mathrm{O}_{2}$ used by each coral fragment was calculated as the difference between the initial and final oxygen concentrations within the chambers. Each run consisted of five incubation chambers, each housing a different coral fragment. The duration that each fragment was kept in a chamber varied depending on respiration rate, ranging from 5 to 7 hours. Measurements of 
individual chambers were terminated if the $\mathrm{O}_{2}$ saturation dropped to a pre-determined $90 \%$. The water volume within each chamber was measured at the end of each experiment.

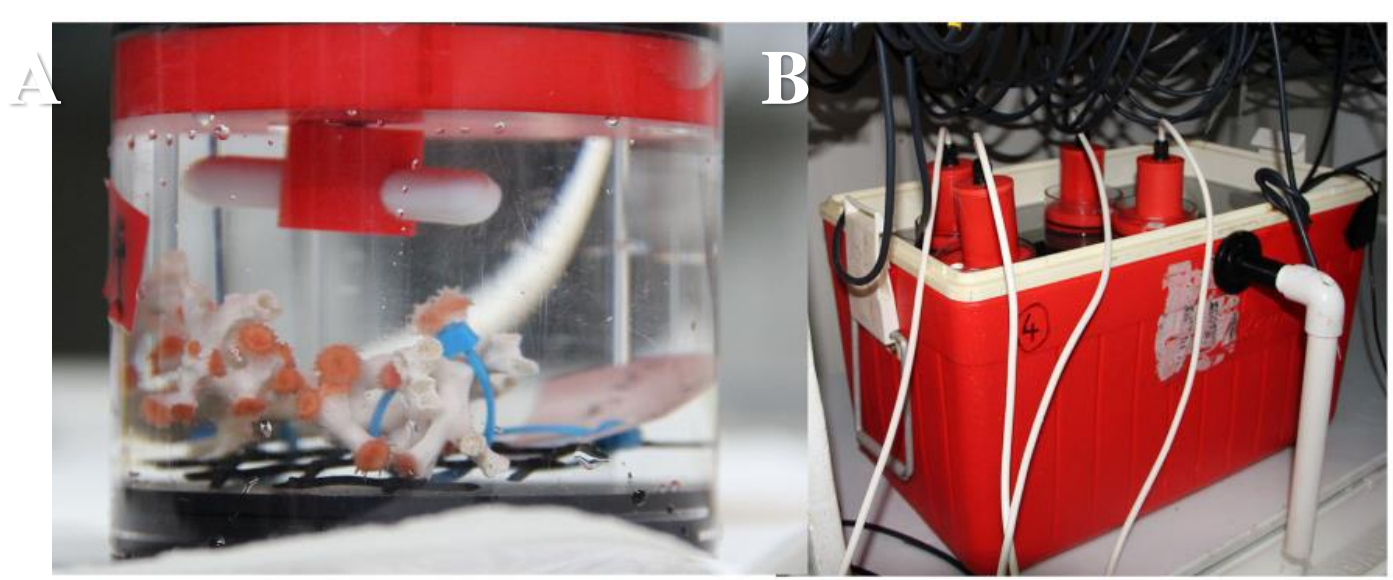

Figure 2.10: The respiration chambers used to measure respiration rates of live Solenosmilia variabilis. Each fragment was held in a respiration chamber (A) and all chambers were kept in a large waterbath at a constant temperature $\left(3.5^{\circ} \mathrm{C}\right)(\mathrm{B})$. Respiration rates were measure via the depletion of oxygen in each chamber (Images: Malindi Gammon).

The $\mathrm{O}_{2}$ concentration in each chamber at the start and end of the experiment was standardised to $\mu \mathrm{g} \mathrm{L}^{-1}$ and an hourly rate of $\mathrm{O}_{2}$ consumption calculated for each individual $\left(\mu \mathrm{g} \mathrm{O}_{2}\right.$ animal ${ }^{-1}$ $\left.\mathrm{h}^{-1}\right)$. A popular method to express metabolic rates of corals is to normalise it in terms of the coral skeleton area (e.g Kanisher \& Wainwright, 1967), but due to the three dimensional complexity of these coral samples this was impractical. Total skeleton dry weight is also often used for normalizing respiration data. However, the nature of the corals sampled here is such that total size of a skeleton does not predict the area of living tissue on each skeleton, and some smaller samples had more living tissue than larger samples. Several other ways for normalizing respiration rate were considered and data gathered for each, including: ash free dry weight 
(AFDW), dry weight, polyp count and tissue protein content. Milligrams of protein content per individual was selected to normalise the respiration data, as it was ultimately felt that this most accurately accounted for the variable state of the samples' health and hence tissue cover.

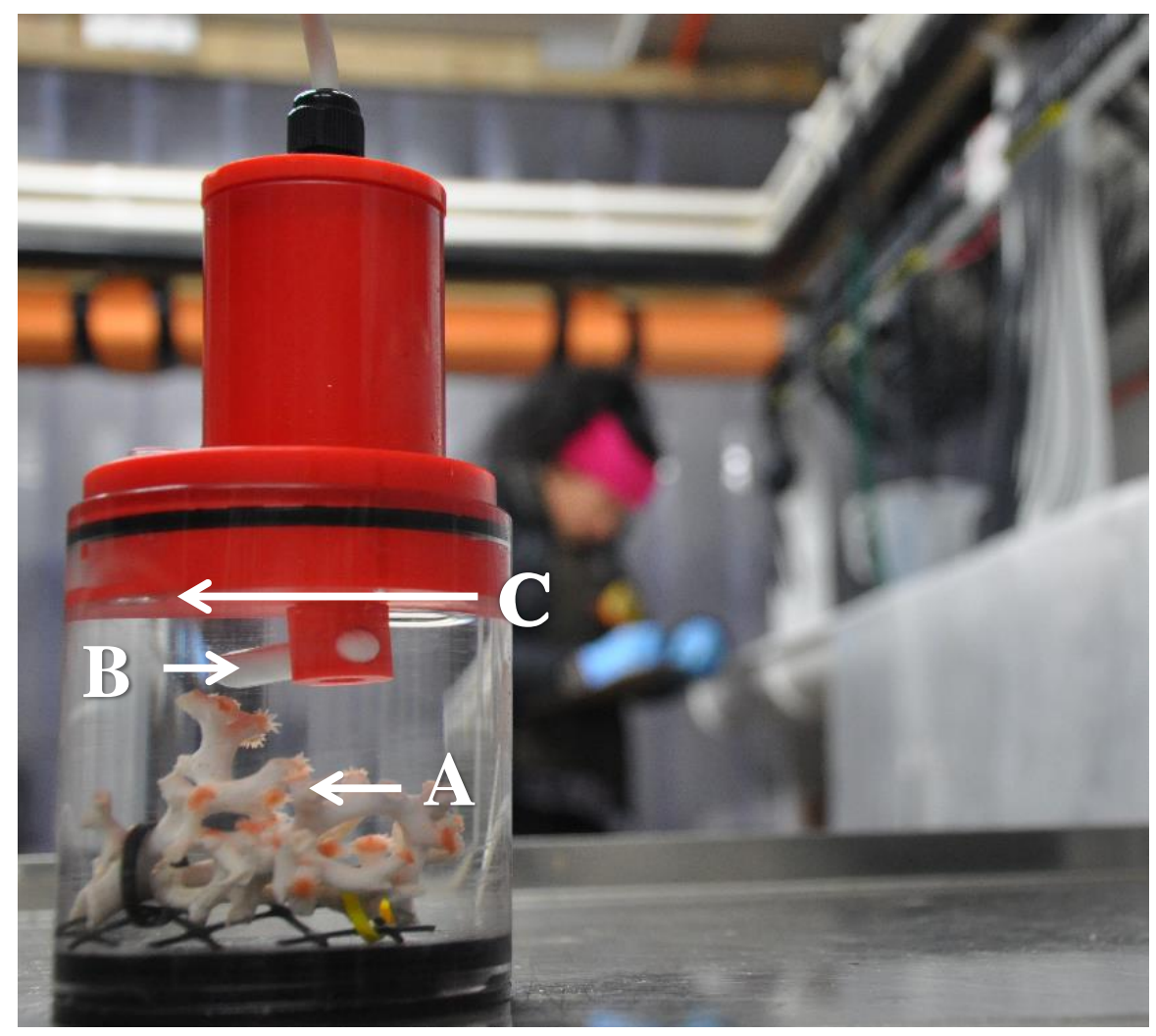

Figure 2.11: Fragment of the deep-sea coral Solenosmilia variabilis in a respiration chamber. After being left to settle, the corals polyps extend (a). The magnetic stirrer (b) ensures that there is constant water movement around the organism and the oxygen content of the chamber can be measure via a sensor spot at the bottom of a glass vial (c) which makes contact with the water within the chamber. (Image: Malindi Gammon).

The total protein content of each coral fragment was determined using the Bradford assay. After respiration measurements, coral samples were transferred to Victoria University of Wellington. Here a sub-sample was immediately taken for measurement of $\mathrm{pHi}$ (see below) and coral colonies were then frozen. Frozen tissue was removed from the skeleton matrix with an 
airbrush; this technique applies small and forceful intermittent jets of distilled water (Johannes \& Wiebe, 1970). The tissue was removed inside a large snap-lock bag containing $5 \mathrm{~mL}$ of distilled water and the protein slurry was poured into a $250 \mathrm{~mL}$ beaker; the snap-lock bag was then rinsed into the beaker twice with $5 \mathrm{~mL}$ of distilled water. The protein slurry was homogenized further using an electric homogenizer (Proxxon micropower driver) and the total quantity of this homogenized material noted. A $5 \mu \mathrm{L}$ subsample of homogenized protein slurry was then transferred to a 96-well plate and analysed with the Coomassie Brilliant Blue protein assay (Bradford, 1976) and a spectrophotometer (EnSpire 2300 Multilabel Plate Reader: PerkinElmer, Waltham, Massachusetts). The protein concentration of each $5 \mu \mathrm{L}$ sub-sample was then adjusted for the total volume of each sample and the total protein content of each individual coral fragment calculated. Respiration rates were expressed as $\mu \mathrm{g} \mathrm{O}_{2} \mathrm{~g}^{-1}$ protein $\mathrm{h}^{-1}$.

\subsection{MEASUREMENTS OF INTRACELLULAR pH (pHi)}

At 9 and 12 months into the experiment, samples were selected at random from the treatment and control groups ( $\mathrm{n}=9$, for each of treatment and control) and the pHi of S. variabilis cells from these samples measured. Ratiometric dyes are widely used for measuring the concentration of particular ions within a living cell (Akimzhanov \& Boehning, 2011), and different dyes are used for identifying the concentration of different ions. Upon excitation with a laser and under different ion concentrations, the dye exhibits a shift between excitation and emission intensities (Fig. 2.12), which can be observed as fluorescent levels under a confocal microscope. Fluorescent dyes used to measure $\mathrm{pH}$ undergo a spectrum shift between excitation and emission intensities which is dependent on the $\mathrm{pH}$ of the cell. Increasing $\mathrm{pH}$ increases fluorescence 
intensity at one wavelength while decreasing it at another, and it is this ratio between the two fluorescence intensities which serves as a measure of $\mathrm{pH}$ (Tsien \& Poenie, 1986).

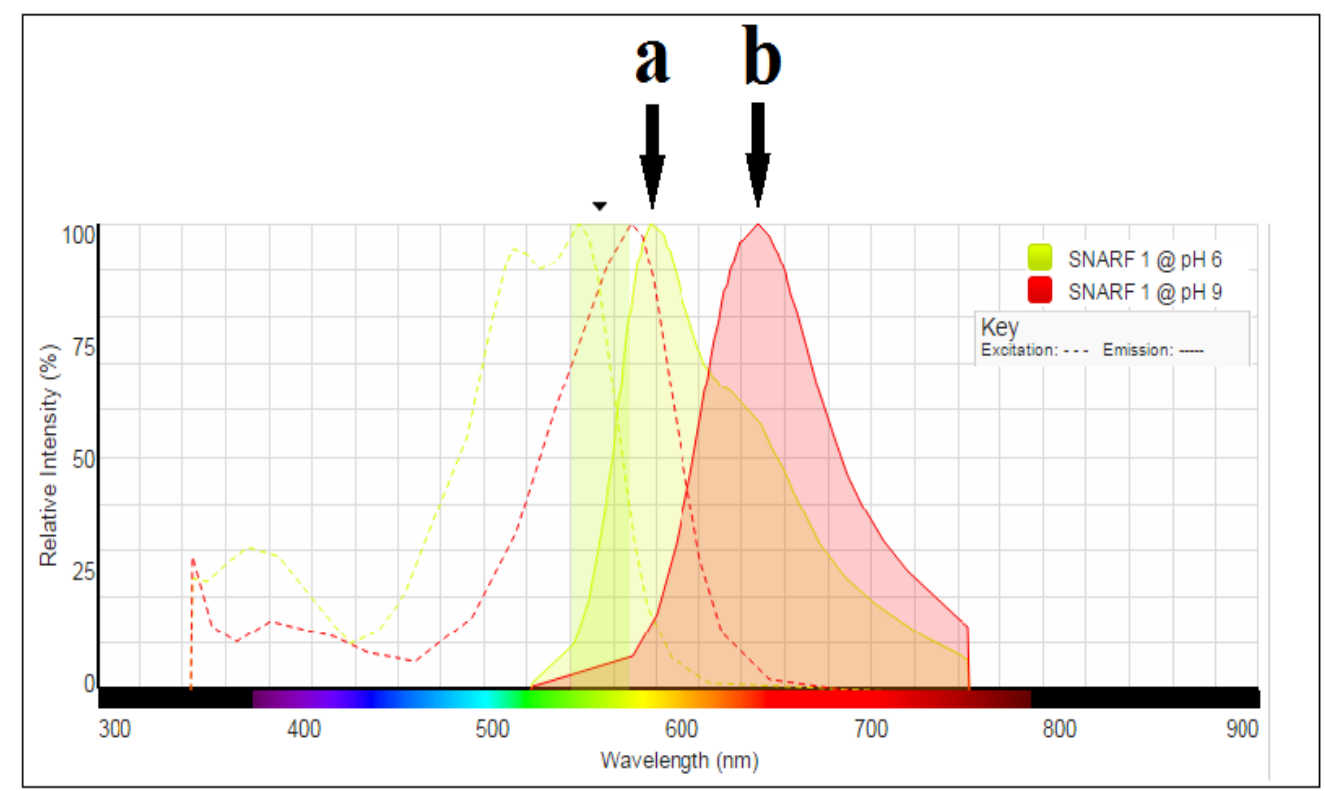

Figure 2.12: The emission spectrum of the ratiometric dye SNARF-1 at different pH levels. Because the excitation (broken lines) and emission values (solid lines) are further apart with increasing $\mathrm{pH}$, incubated cells with a higher $\mathrm{pH}$ emit a lower fluorescent ratio. For example, at a pH of 6 (a), excitation is $\sim 547 \mathrm{~nm}$ and emission is $\sim 585 \mathrm{~nm}$, and the ratio is (R) $585 / 547=1.069$. At $\mathrm{pH} 9$ (b) excitation is $\sim 574 \mathrm{~nm}$ and emission is $\sim 640 \mathrm{~nm}$, and the ratio $(\mathrm{R})$ is $574 / 640 \mathrm{~nm}=0.89$. (Image source: Thermo Fisher Scientific Incorporated, 2016).

\subsubsection{Using SNARF-1 to measure pHi of Solenosmilia variabilis}

The process of conducting this intracellular research involved a considerable amount of method development, and builds on the important work of Venn and colleagues (Venn et al. 2009) and the protocol established by Gibbin \& Davy (2013). The buffer solution used in the creation of 
the calibration curve was designed by Venn et al. (2009), who used the same ratiometric probe. Using the ratiometric dye SNARF-1, the pHi of $S$. variabilis cells were measured. The ratiometric SNARF-1 dye undergoes a pH-dependent shift in emission spectra (Venn et al. 2009; Fig. 2.12) and has been used in conjunction with the dispersant Pluronic F-127 to reduce dye aggregation (Venn et al. 2009, Gibbin \& Davy, 2013). SNARF-1 has previously been used by Venn et al. (2009) to identify the pHi of coral cells isolated from the reef coral Stylophora pistillata and the symbiotic anemone Anemonia viridis. Care was taken to ensure that FSW used in the isolation of coral cells and dye-loading procedures had the same $\mathrm{pH}$ as the seawater that each sample was exposed to throughout the experiment. This was done by taking FSW directly from the treatment or control tanks.

Isolation of cells and dye-loading procedures were repeated nine times for each treatment (treatment or control) and exposure time (9 months or 12 months) $(\mathrm{n}=9$ corals $p e r$ treatment, per time point).A branch tip $(\sim 2-3 \mathrm{~cm})$ was removed from each coral fragment using a pair of nose-pliers. This branch tip was then submerged in FSW and the tissue of a live polyp removed by scraping with a tooth-pick and drawing off the liberated tissue with a pipette, under a dissecting microscope; the end of the pipette tip was cut off to allow for a larger diameter of the pipette tip opening. The tissue sample was then pumped through the pipette three times to gently break it apart, creating a tissue slurry. The resulting slurry was then centrifuged at 1, 000 $\mathrm{x} g$ for 4 min in a temperature controlled room $\left(\sim 4^{\circ} \mathrm{C}\right)$ to obtain a maximum number of cells for each sample. The supernatant was then removed and the cell pellet re-suspended in $100 \mu \mathrm{L}$ FSW. 

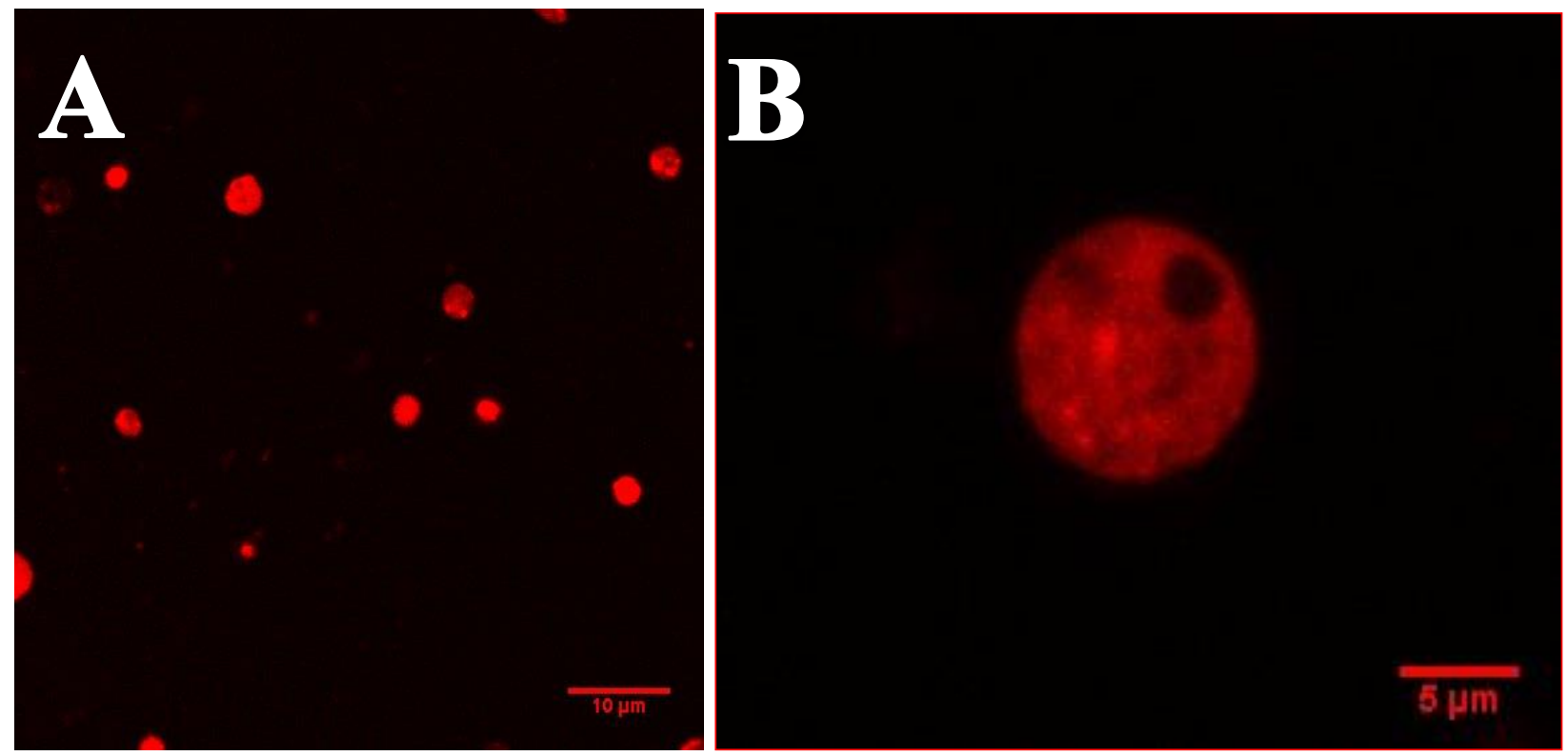

Figure 2.13: A confocal image of Solenosmilia variabilis coral cells incubated in the pH dependent probe SNARF-1 and imaged with a confocal microscope after excitation at $559 \pm 10 \mathrm{~nm}$ and $572 \pm 10 \mathrm{~nm}$ lasers(a); And a single coral cell showing uneven distribution of the fluorescence derived from SNARF-1 (b). This uneven accumulation could be due to selective accumulation into certain organelles and the localised variation of $\mathrm{pH}$ within these organelles. (Image: Malindi Gammon).

To each of the coral cell samples, $10 \mu \mathrm{M}$ SNARF-1 stock with $0.01 \%$ Pluronic F-127 and $0.1 \%$ DMSO were added. Cells were then incubated in the dye for $20 \mathrm{~min}$, in the dark and in an icebox. This was done to keep the cells at the same temperature as they were in the experimental tanks $\left(\sim 3.5^{\circ} \mathrm{C}\right)$. Cells were then centrifuged gently at $1,000 \mathrm{x}$ g for $4 \mathrm{~min}$ and the excess SNARF1 removed. The cell pellet was then re-suspended in $100 \mu \mathrm{L}$ FSW. Confocal microscopy (see below) was initially used to confirm that the dye was able to enter the cell (Fig. 2.13). Despite the use of Pluronic-F127 dispersant, fluorescence of SNARF-1 was not evenly distributed throughout the cell (Fig 2.13, B). This was also observed by Gibbin \& Davy (2013) when using 
the probe BCECF-AM in Symbiodinium cells, and the authors suggested that this could be due to a difference of $\mathrm{pH}$ in specific cell organelles (e.g. Casey et al. 2010).

\subsubsection{Confocal microscopy}

Cells were imaged using a confocal microscope (Fluroview 1000, Olympus, Pennsylvania, USA). Prior optimization of confocal settings was conducted to ensure no loss of the SNARF1 signal. A blank sample (containing no SNARF-1) was first imaged to identify any background fluorescence being emitted from the sample (Fig. 2.14); settings were adjusted to remove this background fluorescence and applied to all consequent images. Fig. 14 shows an image where the confocal settings have not been adjusted to remove background fluorescence.

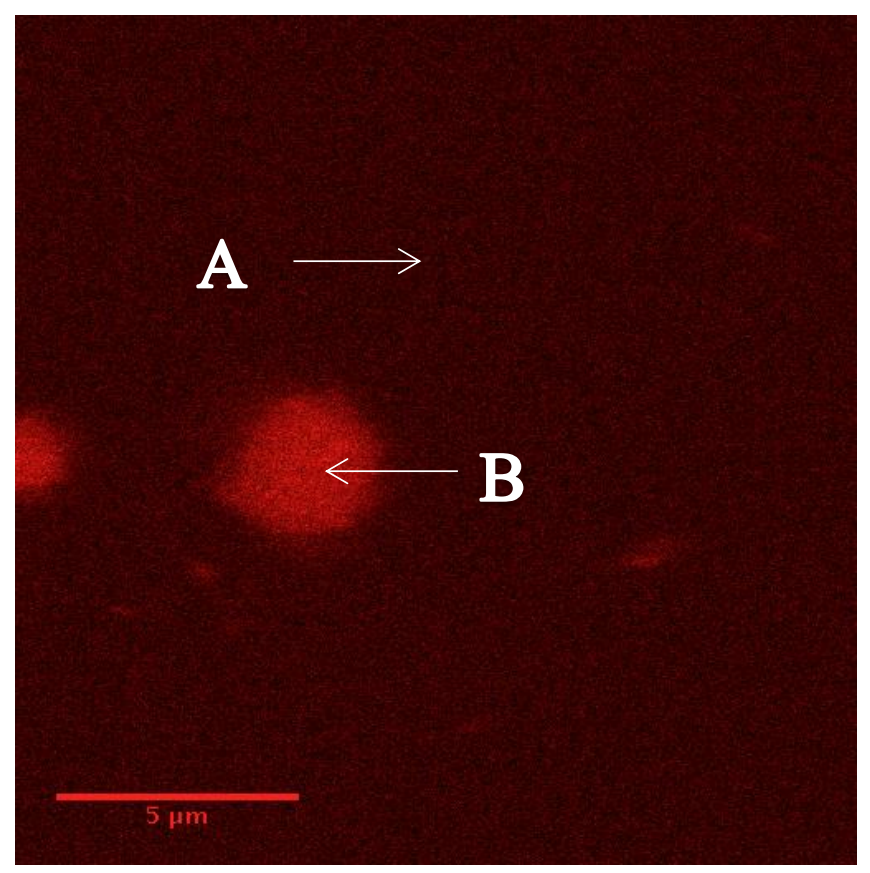

Figure 2.14: An isolated Solenosmilia variabilis cell incubated in the fluorescent probe SNARF-1 and showing the background fluorescent signal. The background signal (a) must be identified and the image adjusted to remove this background signal so that only the cell (b) fluoresces. 
A $10 \mu \mathrm{L}$ sample of each replicate cell slurry, incubated in SNARF-1, was then transferred to a slide. The medium and would not settle long enough to obtain a high-quality confocal image. To solve this, dye-loaded cells were transferred to a microscope slide which was then sealed with nail-varnish and left face down for one hour in darkness to settle. This method ensured that enough cells settled for each sample to be imaged adequately by the confocal microscope. Individual cells were then imaged (x 100 magnification, oil immersion) in $0.5 \mu \mathrm{m}$ slices in the z-plane, with fluorescence emission captured at $559 \pm 10 \mathrm{~nm}$ and $572 \mathrm{~nm} \pm 10 \mathrm{~nm}$ (Fig. 2.13). Three cells per replicate coral fragment were imaged to account for any inherent variability.

\subsubsection{Calibration of $\mathrm{pH}$ in cnidarian cells}

A calibration curve (Fig. 2.15) was created to identify the pHi of a S. variabilis cell based on the fluorescence of SNARF-1. Isolated S. variabilis cells were incubated in buffer solutions of known $\mathrm{pH}$ from $\mathrm{pH}$ 6-8.5 and in the presence of $5 \mu \mathrm{mol} \mathrm{L}^{-1}$ nigericin (Venn et al. 2009). Nigericin inhibits the cell's sodium-potassium pump, equilibrating the internal $\mathrm{pH}$ of the cell with that of the medium it is incubated in. The ratio of fluorescence intensity of SNARF-1 at $559 \pm 10 \mathrm{~nm}$ and $572 \pm 10 \mathrm{~nm}$ was then calibrated in the $\mathrm{pH}$ range 6-8.5 using $S$. variabilis cells.

Importantly, the pHi of the two time points cannot be compared. This is due to the fact that only one calibration curve was created during measurements of $\mathrm{pHi}$ for the first time point (nine months). The same calibration curve was applied to the second time point, but it was later discovered that the irradiance of the fluorescent probe had declined over time. For this reason, only data from the first time point (nine months) provide an absolute value of $\mathrm{pHi}$ for both the treatment and control groups. Data from the second time-point (12 months) can only provide a relative comparison of $\mathrm{pHi}$ between the treatment and control groups, and do not provide a reliable estimate of absolute $\mathrm{pHi}$. 


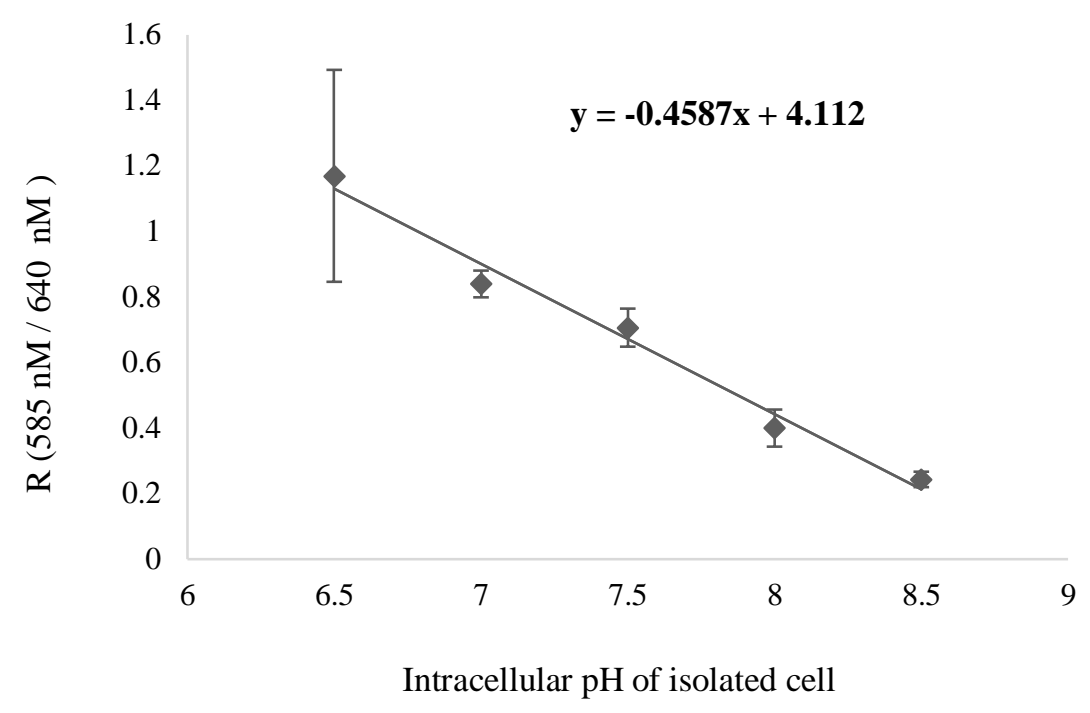

Figure 2.15: Calibration of the intracellular $\mathrm{pH}$ (pHi) of isolated Solenosmilia variabilis cells with the fluorescent ratio signal of SNARF-1. This curve was created by incubating cells in a buffer of known $\mathrm{pH}$ (x-axis) and measuring the fluorescent signal of SNARF-1 at that $\mathrm{pH}$. The equation of this curve was then used to determine the $\mathrm{pH}$ of isolated cells from the experiment, based on the fluorescent signal emitted by SNARF-1.

\subsubsection{Image analysis}

All images taken for analysis were analysed using the imaging software ImageJ. This ratio is determined using the Ratio_Profiler plugin for the software ImageJ. For each sample, a region of interest (ROI) was selected and analysed for the ratio of fluorescence intensities (R). The plugin calculates $(\mathrm{R})$ for each $\mathrm{ROI}$ sample; $\mathrm{R}$ is then converted to $\mathrm{pH}$ by using the calibrated equation (Fig. 2.15). 


\subsection{STATISTICAL ANALYSES}

All statistical analyses and graphs were constructed using the statistical software package SPSS.

\subsubsection{Polyp mortality and buoyant weight}

Data for both polyp mortality and changes in buoyant weight were not normally distributed and the assumption of normality could not be met using log transformations. A Friedman test was used as a non-parametric alternative to the one-way ANOVA with repeated measures (rmANOVA). Data were categorized into 12 groups which represented each of the time points (0, 2, 4, 6, 8 and 10 months' exposure) at the treatment and control $\mathrm{pH}$.

\subsubsection{Linear growth rate}

In order to determine linear growth rate, the difference between the linear lengths of each branchlet, for each sample, was compared between each time-point and linear growth calculated as mm linear extension per year. A rm- ANOVA was used to compare the average growth rate of individuals from the control group and individuals from the treatment group.

\subsubsection{Tissue loss}

Data for the loss of coenosarc were not normally distributed and the assumption of normality could not be met using log transformations. A Friedman test was used as a non-parametric alternative to the rm-ANOVA. Data were categorized into 12 groups that represented each of the time-points $(0,2,4,6,8$ and 10 months' exposure $)$ at the treatment and control $\mathrm{pH}$. 


\subsubsection{Respiration rate}

Respiration data were $\log$ transformed to meet the assumption of normality. The significant effect of treatment, and interactive effect of time since exposure with treatment, were tested using a two-way ANCOVA. Respiration chamber and seamount of origin were included as covariates, to ensure that they had no confounding effects on the response variable.

\subsubsection{Intracellular $\mathrm{pH}$}

To test the effect of external $\mathrm{pH}(\mathrm{pHe})$ on the $\mathrm{pHi}$ of isolated coral cells, a non-parametric Kruskal-Wallis test was used as data were not normally distributed and the assumption of normality could not be met by transforming the data. Data were categorized into four treatments which depended on the $\mathrm{pH}$ level that they were kept at and for how long: $\mathrm{pH} 7.85,9$ months; pH 7.65, 9 months; pH 7.85, 12 months; and pH 7.65, 12 months. 
3. Results 


\subsection{COLONY GROWTH, MORPHOLOGY AND HEALTH}

\subsubsection{Buoyant weight}

Throughout the experiment there was a general trend of a loss in buoyant weight at reduced $\mathrm{pH}$ (Friedman test, $\chi^{2}(11)=163.359, \mathrm{p}=0.001$; Fig. 3.1). Post hoc analysis (Wilcoxon-signed rank analysis) found that this loss was significant after 6,8 and 10 months, with a steady decline across the 10-month period resulting in corals weighing $86.757 \% \pm 2.880 \%$ of their starting weight. At the control $\mathrm{pH}$, corals largely maintained their initial buoyant weight.

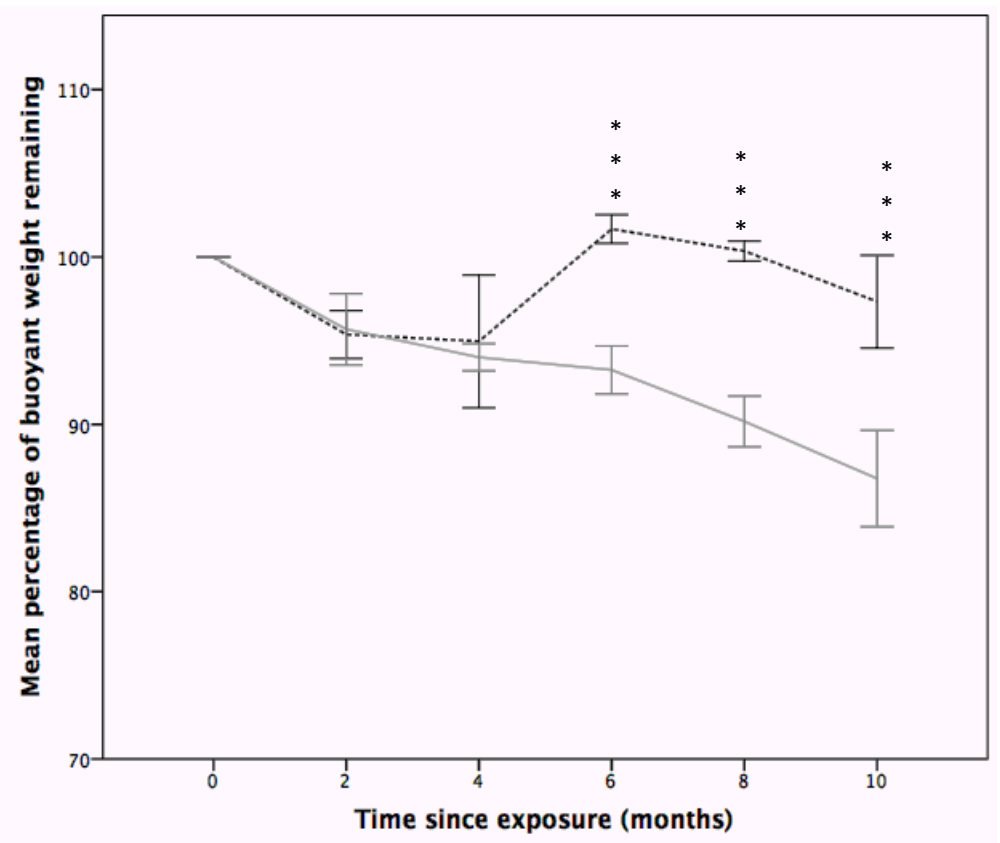

Figure 3.1: The effect of seawater $\mathrm{pH}$ on buoyant weight (\% of initial weight remaining) of Solenosmilia variabilis. S. variabilis colonies were exposed to pH 7.88 (control; broken line) or pH 7.65 (treatment; solid line). Measurements of buoyant weight were conducted bi-monthly over a 10-month period. Significant differences from the control (Wilcoxon-signed rank test) are shown by $* * * \mathrm{p}<0.001$. ( $\mathrm{n}=17$ per treatment per time-point; values are means $\pm 1 \mathrm{SE})$. 


\subsubsection{Polyp mortality}

A visible loss in polyp mortality was noted throughout the experiment (Fig. 3.2). No polyp mortality occurred in the first two months in either the control or treatment $\mathrm{pH}$, but polyp mortality then increased over time (Fig. 3.3); while there was a significant difference between each of the treatment categories (Friedman test, $\chi 2(11)=107.769, \mathrm{p}=0.001$ ), post hoc tests (Wilcoxon-signed rank test) showed that these differences were between different time-points of the same treatment and that there was no change in polyp mortality within the treatment group, relative to the control. However, after six months, polyp mortality was consistently higher in the low $\mathrm{pH}$ group.

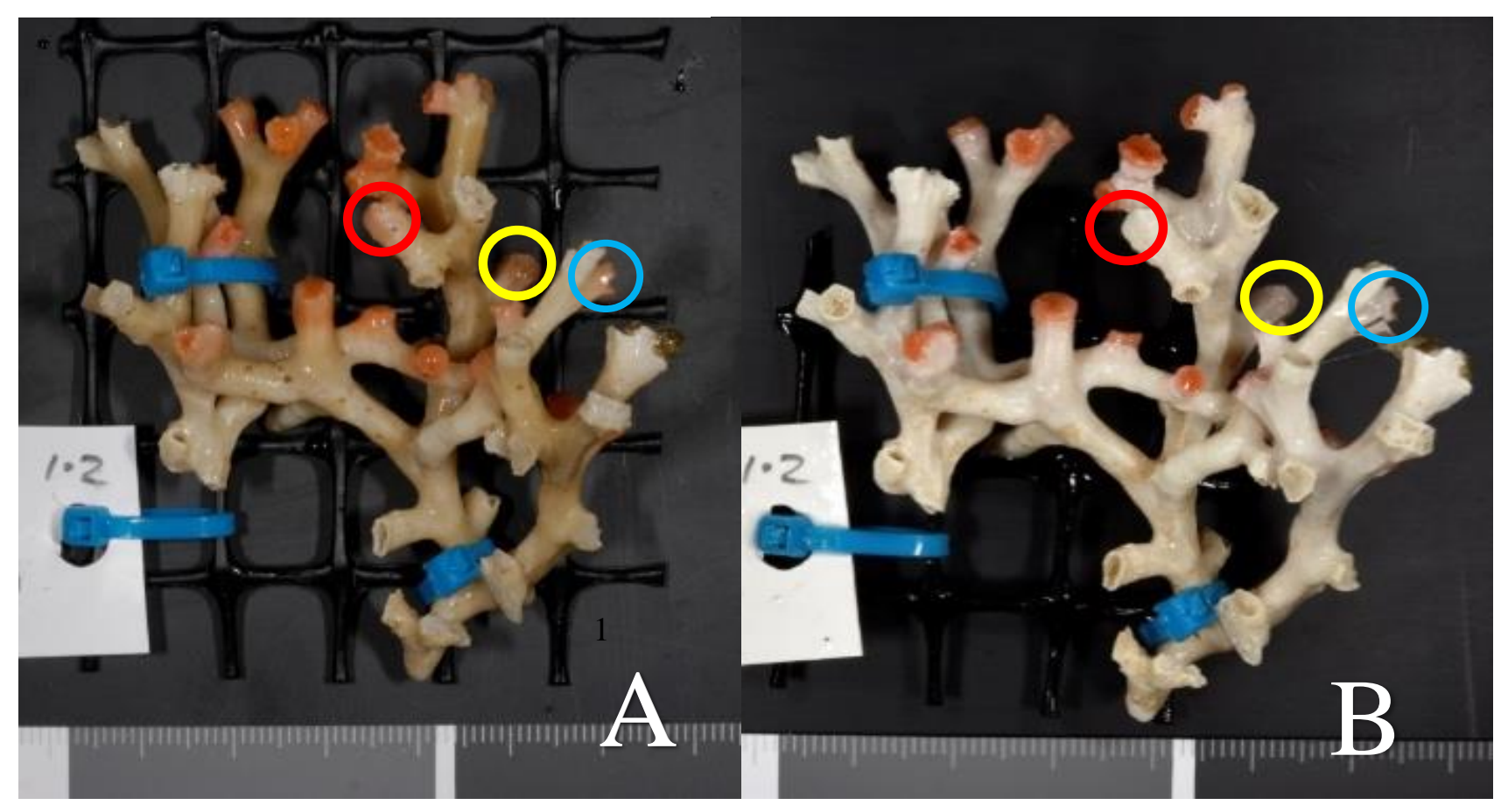

Figure 3.2: A visualization of polyp mortality in Solenosmilia variabilis, resulting from reduced seawater pH. This figure shows two images of a $S$. variabilis colony taken before the experiment began (A) and after six months of exposure (B) to a reduced $\mathrm{pH}$ treatment. Polyp mortality was identified through a visible loss in the pink colouration at the branch tips and is illustrated by the red, yellow and blue circles in this image. 
The greatest loss in polyp mortality occurred in the low $\mathrm{pH}$ group from four (where colonies still had $92.04 \% \pm 7.45$ of their polyps remaining) to six months of exposure (where colonies only had $61.58 \% \pm 7.19$ of their polyps remaining) (Fig. 3.3). The difference between these two time-points represents a loss of $30.46 \%$ of initial polyp counts over just a four-month period.

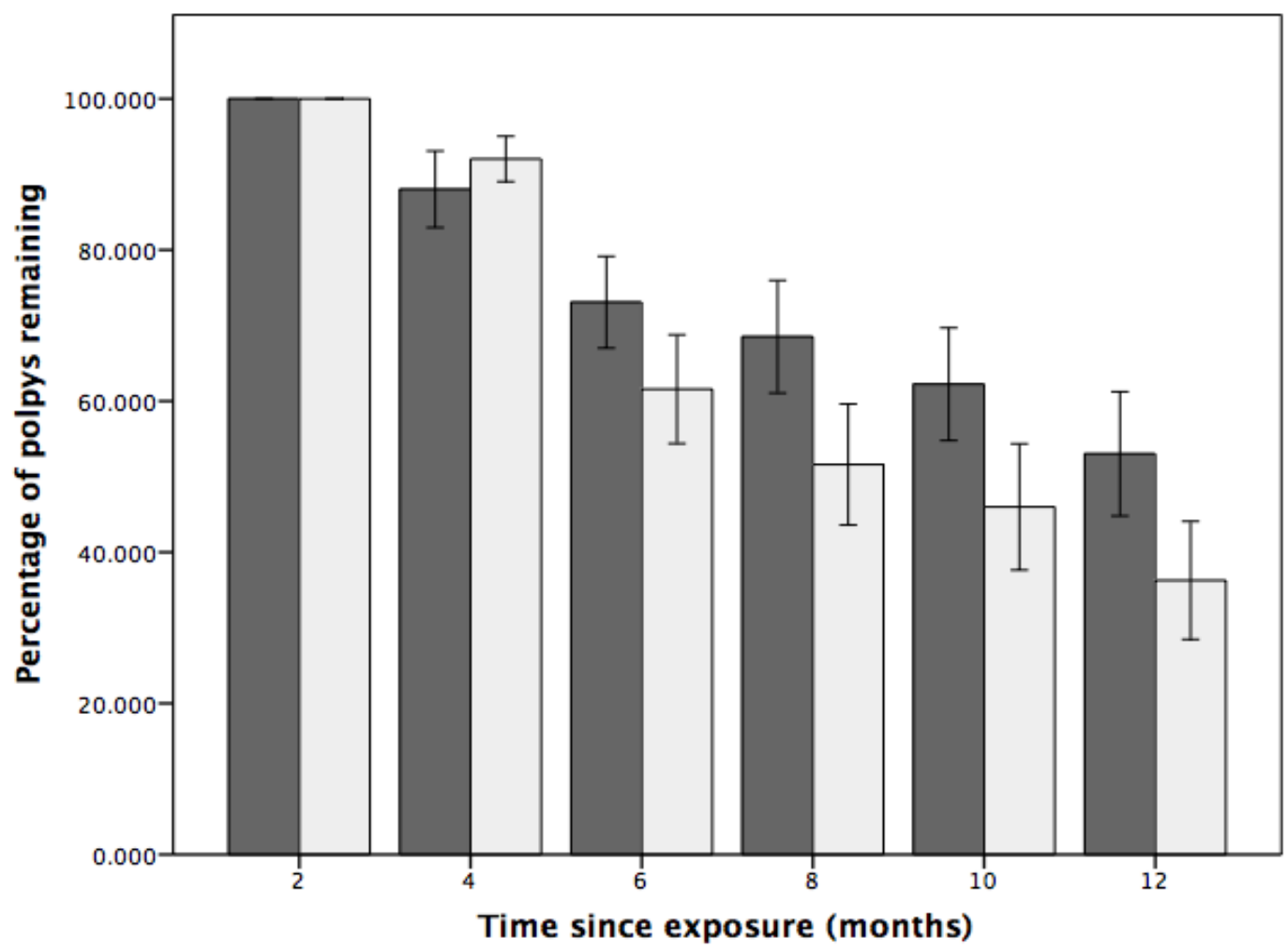

Fig. 3.3 The effect of seawater pH on the average polyp mortality in Solenosmilia variabilis. The bars represent the values are the percentage remaining of the initial polyp count for $S$. variablis fragments when exposed to $\mathrm{pH} 7.88$ (control; dark grey) or $\mathrm{pH}$ 7.65 (treatment; light grey) $(n=17$; values are means $\pm S E)$. At each time-point, the response variable did not differ significantly between the treatment and control. 


\subsubsection{Linear growth rate}

The potential impact of seamount origin was tested via a rm-ANCOVA model, but had no effect on the linear extension rate of the treatment colonies $\left(\mathrm{F}_{4,40}=0.769, \mathrm{p}=0.552\right)$ and control colonies $\left(\mathrm{F}_{4,52}=0.577, \mathrm{p}=0.681\right)$. For both the reduced $\mathrm{pH}$ and control groups, time did not significantly affect growth rate $\left(\mathrm{F}_{4,40}=0.481, \mathrm{p}=0.749\right.$ and $\mathrm{F}_{4,52}=0.274, \mathrm{p}=0.893$, respectively). For these reasons, both seamount origin and time of exposure were excluded from the final model. An rm-ANOVA test found no effect of reduced $\mathrm{pH}$ treatment $(\mathrm{pH} 7.65)$ on the linear extension rate of S. variabilis $\left(\mathrm{F}_{1,25}=0.017, \mathrm{p}=0.899\right.$; Fig. 3.4 $)$. 


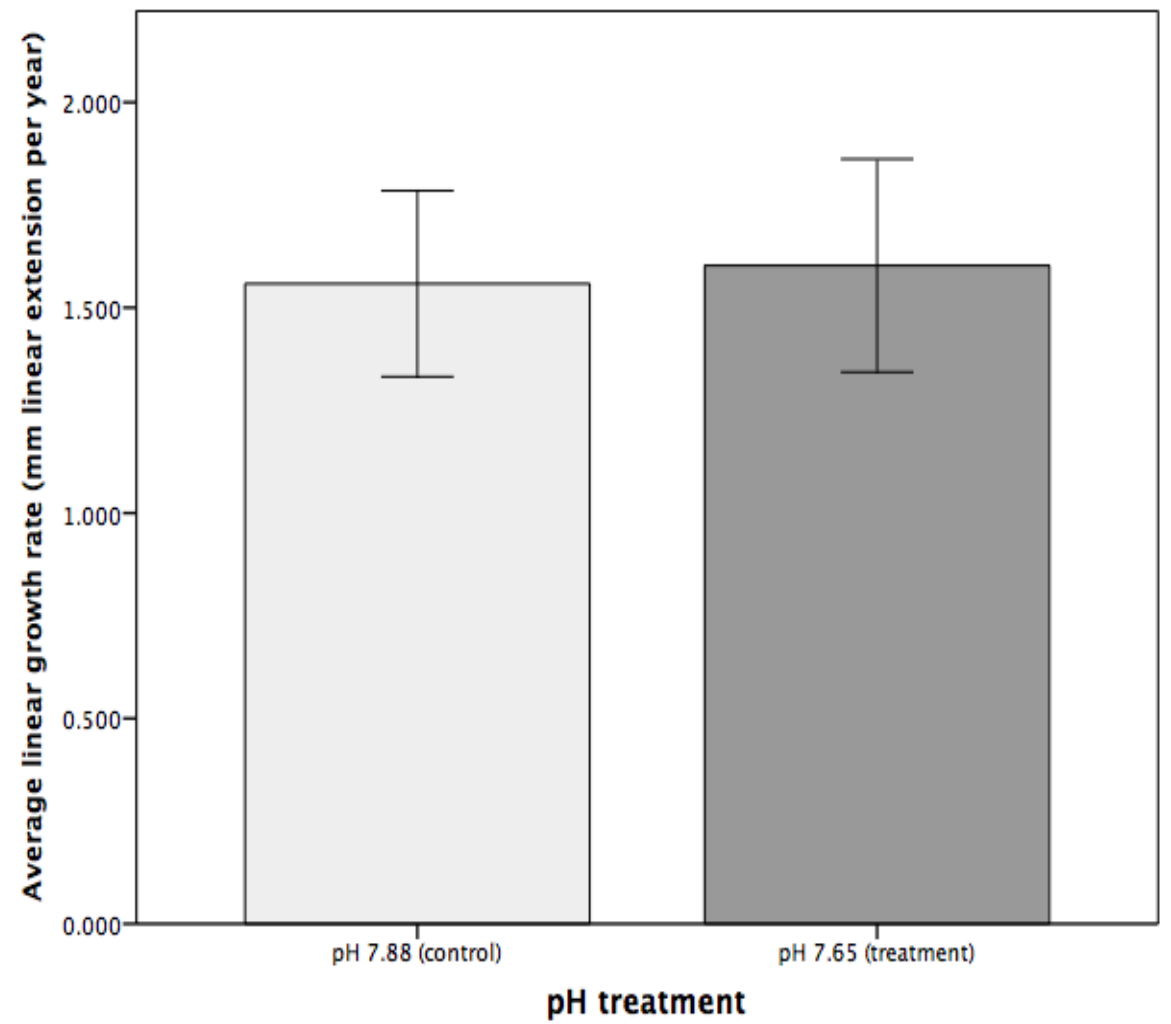

Figure 3.4: The effects of external $\mathrm{pH}$ on the linear growth rate of the deep-sea coral Solenosmilia variabilis. Corals were exposed to control $(\mathrm{pH} 7.88)$ or reduced $\mathrm{pH}(\mathrm{pH}$ 7.65) for 10 months and the data from each time-point (taken every two-months) were pooled to obtain average linear growth rate. $\mathrm{pH}$ treatment did not have a significant effect on the linear extension of colonies $(n=18$ per treatment per time-point; values are means \pm SE.

The average linear extension rate at the control $\mathrm{pH}$ was $1.558 \pm 0.226 \mathrm{~mm}_{\text {year }}{ }^{-1}$ and at reduced $\mathrm{pH}$ was $1.603 \pm 0.260 \mathrm{~mm}$ year ${ }^{-1}$. Growth rates were highly variable between individual coral fragments, ranging from 0.583 to $3.068 \mathrm{~mm}$ year $^{-1}$

\subsubsection{Respiration rate}

The respiration rate of corals was independent of $\mathrm{pH}$ treatment (two-way ANOVA, $\mathrm{F}_{1,24}=$ 3.200, $p=0.086$; Fig. 3.5), but there was a significant effect of time (two-way ANOVA, $F_{1,24}$ 
$=0.977, \mathrm{p}=0.007$ ). There was no interactive effect between $\mathrm{pH}$ treatment and time (two-way ANOVA: $\mathrm{F}_{1,24}=0.101, \mathrm{p}=0.350$ ).

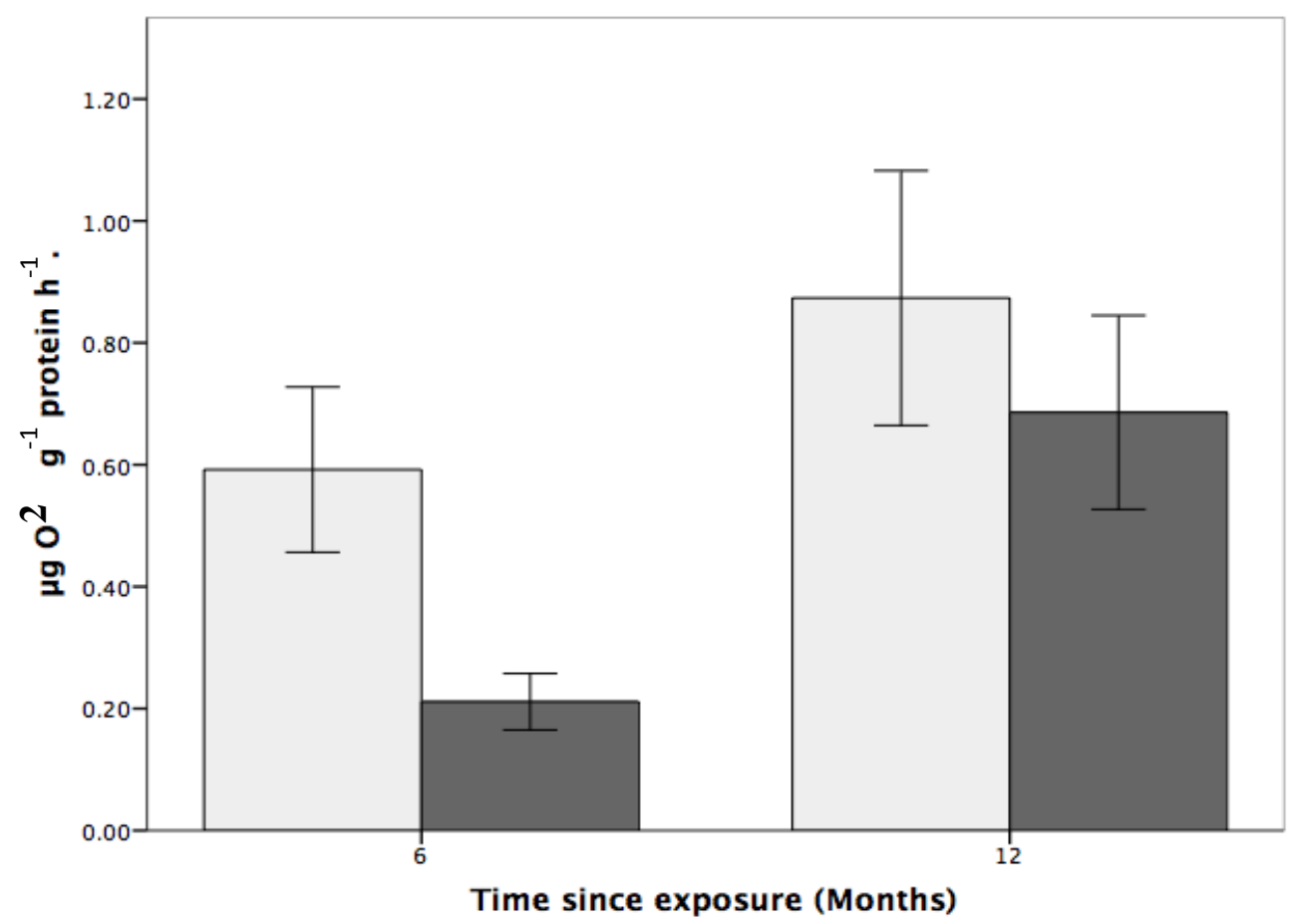

Figure 3.5: The effects of seawater $\mathrm{pH}$ on the respiration rate of Solenosmilia variabilis. Respiration rate $\left(\mu\right.$ mol $\mathrm{O}_{2} \mathrm{~g}^{-1}$ protein $\left.\mathrm{h}^{-1}\right)$ of colonies after exposure to reduced $\mathrm{pH}(\mathrm{pH}$ 7.65- dark grey) or ambient $\mathrm{pH}$ ( $\mathrm{pH} 7.88$-light grey) for six and 12 months. ( $\mathrm{n}=9$ for each treatment and timepoint; values are means \pm SE.

For colonies in the control group $(\mathrm{pH} 7.88)$, respiration rate was $179 \%$ and $31 \%$ higher than for coral colonies exposed to low $\mathrm{pH}(\mathrm{pH}$ 7.65) for six months and 12 months, respectively. Also of note, the respiration rate at reduced $\mathrm{pH}$ increased by $225 \%$ between the six- and 12 -month time-points. 


\subsubsection{Tissue (coenosarc) loss}

Reductions in the intensity of the red colour channel were assumed to be a proxy for loss of coenosarc tissue. There was a statistically significant effect of $\mathrm{pH}$ on the colour (and hence tissue cover) of the corals (Friedman test, $\chi 2(11)=130.617, \mathrm{p}=0.001$; Fig 3.6).

A post-hoc Wilcoxon-signed rank analysis showed that the loss in relative intensity differed significantly between the control and treatment groups at 2, 4, 6, 8 and 10 months, with the loss of colour intensity being greater at the lower $\mathrm{pH}$ for all five time-points (Fig. 3.6). Both control and treatment groups lost colour, however.

After just two months, there was a significant difference between the remaining colour intensity of the control group $(97.61 \% \pm 1.933)$ and the low $\mathrm{pH}$ group $(94.396 \% \pm 0.738)$, and after ten months of exposure there was, on average, a difference of $5.28 \%$ between the percentage of initial colour remaining between the treatment and control groups. 


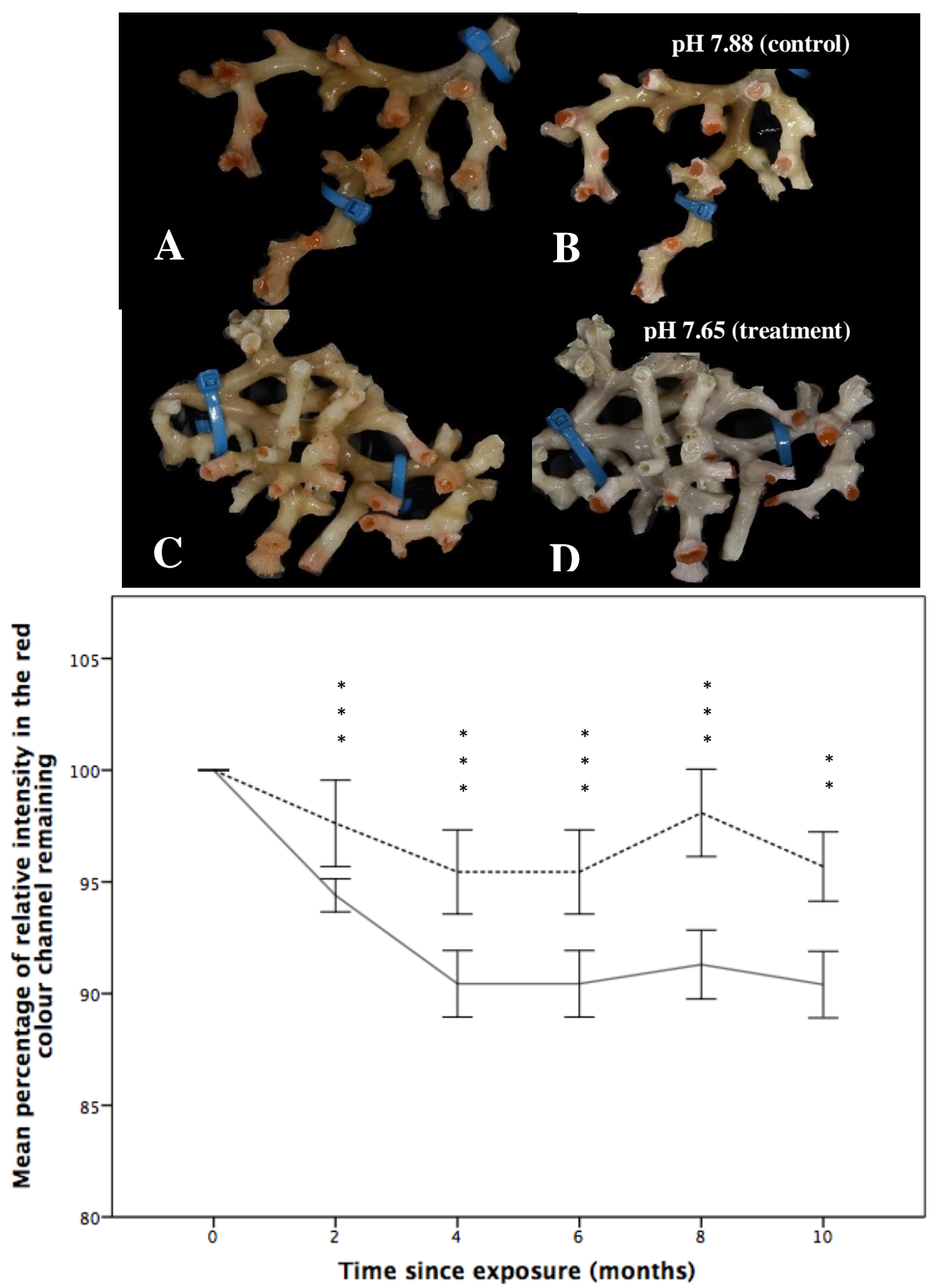

Figure 3.6: The effect of seawater $\mathrm{pH}$ on the loss of coenosarc tissue of the coral Solenosmilia variabilis. Images $\mathrm{A}-\mathrm{B}$ are of the same colony at ambient $\mathrm{pH}(\mathrm{pH}$ 7.88). Images $\mathrm{C}-\mathrm{D}$ are of the same colony at the treatment $\mathrm{pH}(\mathrm{pH} 7.65)$. Images were taken before the experiment began ( $\mathrm{A}$ and $\mathrm{C})$ and after three months into the experiment (B and D). Note the marked paling when the coral was exposed to low $\mathrm{pH}$ for several months (D). Photos of S. variabilis were analysed for the relative percentage of intensity in the red colour channel ( $\mathrm{n}=17$ per time-point per treatment). The mean percentage remaining $( \pm 1 \mathrm{SE})$ of the initial relative intensity is presented. Significant differences from the control are shown by $* * \mathrm{p}<0.01$ and $* * * \mathrm{p}<0.001$ (Wilcoxon-signed rank analysis). 


\subsection{INTRACELLULAR PH}

Fluorescent labelling of pHi appeared to be consistent across suspensions of isolated coral cells

(Fig. 3.7). The $\mathrm{pH}$ of the surrounding seawater did not have a significant effect on the $\mathrm{pH}_{\mathrm{i}}$ of isolated cells (Kruskal-Wallis, $\mathrm{F}_{1,35}=2.674, \mathrm{p}=0.111$ ) (Fig. 3.8), though $\mathrm{pHi}$ did differ with time (Kruskal-Wallis, $\mathrm{F}_{1,35}=8.422, \mathrm{p}=0.006$ ) (Fig. 3.8) with the pHi being higher after 12 months than it was after 6 months. There was no interactive effect between the $\mathrm{pH}$ of seawater and time (Kruskal- Wallis, $\left.\mathrm{F}_{1,35}=0.434, \mathrm{p}=0.515\right)$.

The lowest $\mathrm{pHi}$ was recorded in the control group after nine months and was found to be $\mathrm{pH}$ $7.67 \pm 0.08$. The $\mathrm{pHi}$ of the treatment group for the same time-point was $0.31 \mathrm{pH}$ units higher, at $\mathrm{pH} 7.98 \pm 0.21$. The $\mathrm{pHi}$ of both the treatment and control groups increased over the 12 month experiment, with the $\mathrm{pHi}$ of the control group being $\mathrm{pH} 8.16 \pm 0.13$ and the $\mathrm{pHi}$ of the treatment group being $8.30 \pm 0.06$. 


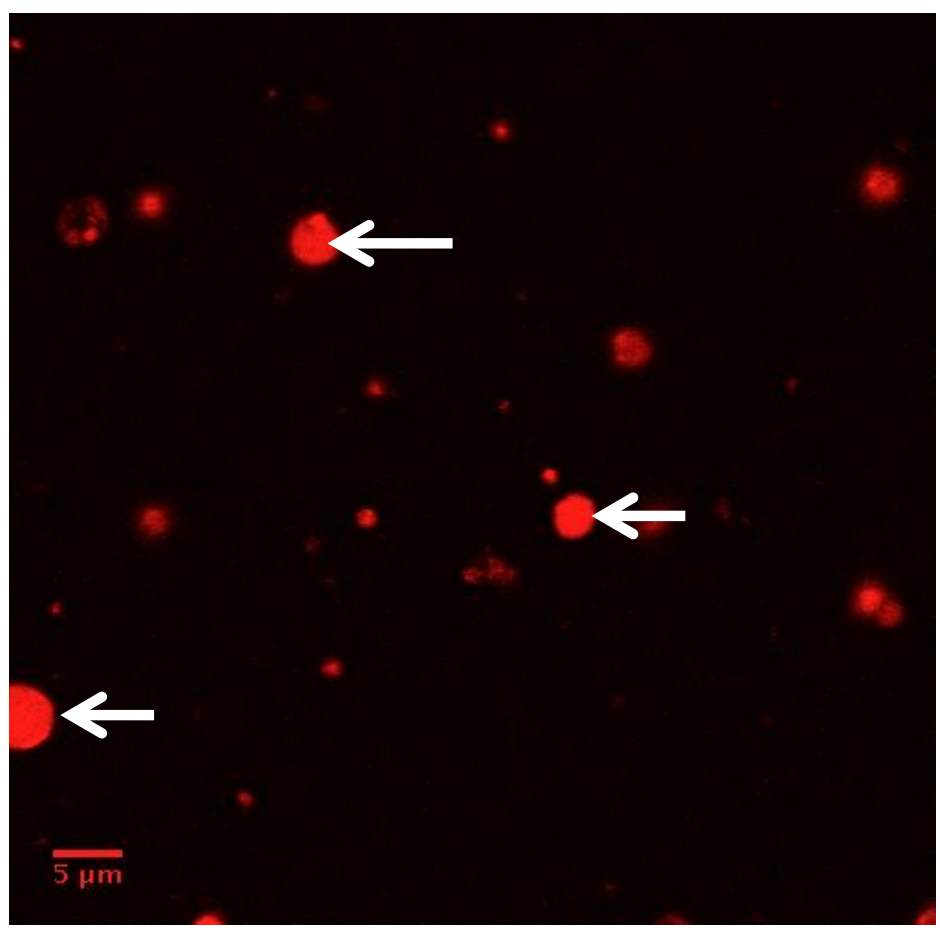

Figure 3.7: Multiple and isolated Solenosmilia variabilis cells incubated in the fluorescent probe SNARF-1. The red fluorescence can be used to determine the intracellular $\mathrm{pH}(\mathrm{pHi})$ of each individual cell. Only those cells which have settled on the coverslip surface (those marked with an arrow) could be analysed for $\mathrm{pHi}$. 


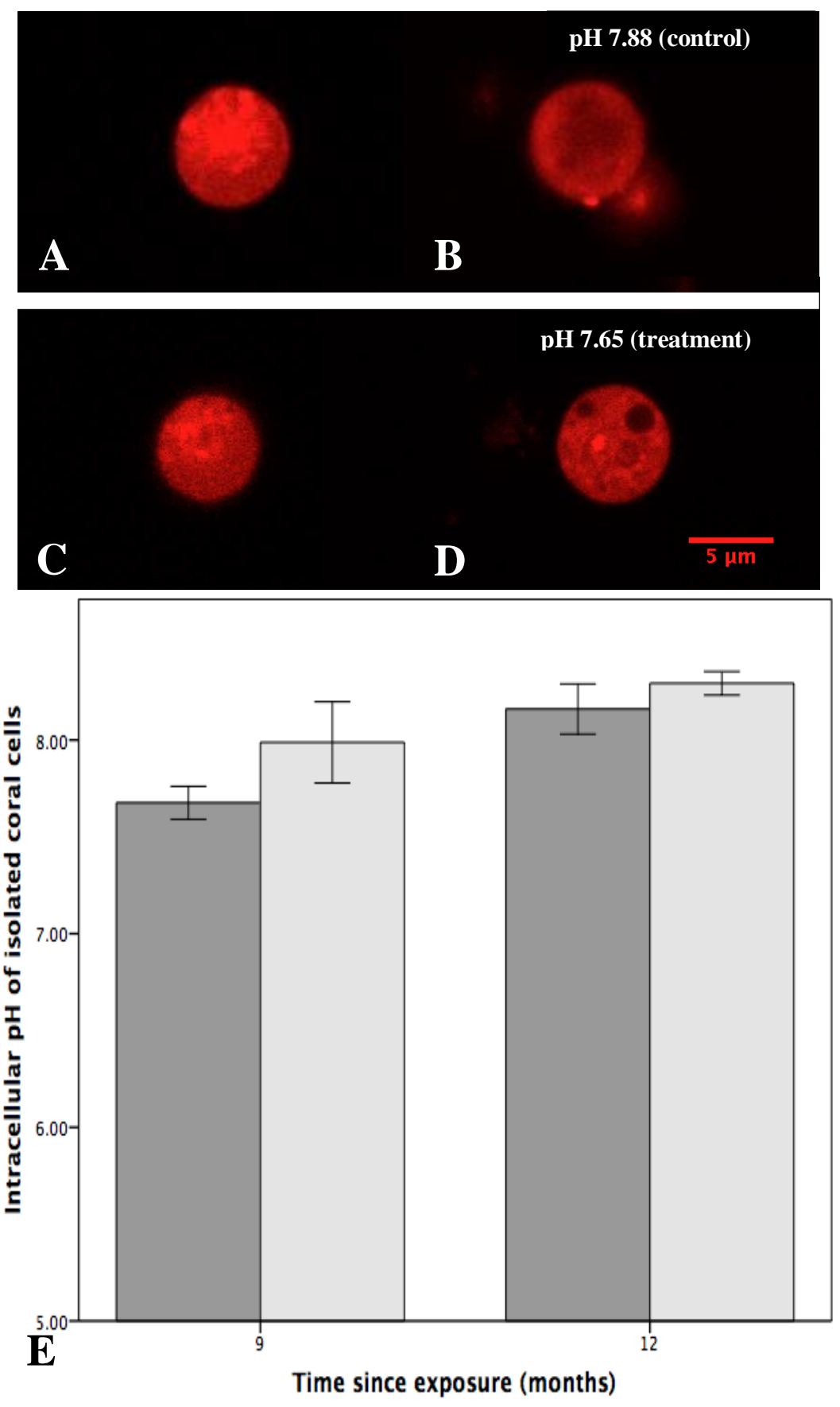

Figure 3.8: The impact of the external pH of seawater on the intracellular pH (pHi) of isolated Solenosmilia variabilis cells. Cells were isolated and imaged using confocal microscopy and the $\mathrm{pH}-\mathrm{dependent}$ fluorescent probe SNARF-1 after nine months of exposure, from both the control (A) and treatment (C) colonies; and after 12 months of exposure, from both the control (B) and treatment (D) colonies. The dark grey bars (E) represent the average $\mathrm{pHi}$ of cells isolated from colonies held at an ambient control $\mathrm{pH}$ $(\mathrm{pH} 7.88)$. The light bars (E) represent the average $\mathrm{pHi}$ of cells isolated from colonies held at reduced $\mathrm{pH}(\mathrm{pH} 7.65)(\mathrm{n}=9$ for each treatment and time-point; values are means $\pm \mathrm{SE})$. 
4. Discussion 


\subsection{SUMMARY OF FINDINGS}

This research set out to investigate the physiological response of the deep-sea coral to OA. Colonies were held for 12 months in tanks with a seawater $\mathrm{pH}$ of $7.65 \mathrm{or} \mathrm{pH} 7.88$. These $\mathrm{pH}$ values were designed to either reflect the current ambient $\mathrm{pH}$ from where corals were sampled ( $\mathrm{pH} 7.88$ ) or the end-of-century projections for a decline in the $\mathrm{pH}$ of seawater due to the oceanic sequestration of anthropogenic $\mathrm{CO}_{2}(\mathrm{pH} 7.65)$ (IPCC, 2013). Throughout this discussion, colonies exposed to $\mathrm{pH} 7.88$ will be referred to as 'control' colonies and colonies exposed to a $\mathrm{pH}$ of 7.65 will be referred to as 'treatment' colonies. Physiological responses were determined by measurements of several key parameters, including: growth (linear extension and buoyant weight), respiration, progressive loss of tissue and $\mathrm{pHi}$. The design of this study was based around the following three research questions:

1) Does OA cause a decline in growth rate and a change in morphology in $S$. variabilis?

Due to a combination of physiological stress and a shift in the energy balance of S. variabilis colonies, it was expected that the growth rate of treatment colonies would be less than the growth rate of control colonies.

2) Does OA induce signs of physiological stress in this coral?

It was expected that the treatment colonies would be under physiological stress, requiring more energy for calcification, and that these factors would lead to a decline in overall health (primarily indicated by a loss in tissue). Research indicating an increase in the energy demand of calcification under reduced $\mathrm{pH}$ (Wood et al. 2008) informed the second part of this hypothesis: that the 
respiration rate of treatment colonies would increase relative to control colonies. It was thought that respiration rates would increase as a product of physiological stress, and to accommodate the increased energy requirements of calcification.

3) Does OA lower the pHi in this coral?

It was hypothesised that the pHi of coral cells isolated from treatment colonies would decline with $\mathrm{OA}$, alongside a decline in the external $\mathrm{pH}$ of seawater.

Contrary to the above hypotheses, this research found that the $\mathrm{pHi}$, respiration rate, coral density and coral growth did not respond to OA in the timeframe used here. While polyp mortality was however also unaffected, there was a marginally $(6.79 \%)$ greater loss of tissue at reduced seawater $\mathrm{pH}$ than under control conditions. Despite there being no observable decline in linear growth rate between the treatment and control groups, there was a loss of buoyant weight in the treatment group. Given that this group also showed a loss of surface tissue, it is assumed that the observed decline in buoyant weight is due to this tissue loss.

This research was designed to test the impact of OA conditions predicted for the end of this century on $S$. variabilis, and therefore the treatment represents an ecologically relevant scenario. While the results of this research indicate some insensitivity of $S$. varaibilis to OA, a significant loss of tissue was observed in the treatment group. As discussed later in this chapter, this loss of tissue could represent the first stages of phenotypic plasticity in response to environmental change. It is also important to consider the possibility of a threshold response and how multiple stressors (i.e. a suite of changes occurring alongside OA, including: changes to species interactions, an increase in ambient temperature and decrease in nutrient availability) may influence the 
response of S. variabilis to OA. Whilst these multiple stressor scenarios were beyond the scope of this research, it is recommended that they be investigated further before any broad conclusions can be drawn, and are discussed later in this chapter.

\subsection{THE IMPACTS OF OA ON THE GROWTH AND}

\section{MORPHOLOGY OF SOLENOSMILIA VARIABILIS}

The average linear extension per year for control colonies was $1.558 \pm 0.226 \mathrm{~mm}$ and for treatment colonies was $1.603 \pm 0.260 \mathrm{~mm}$ (range 0.583 to $3.068 \mathrm{~mm}^{-1} \mathrm{ar}^{-1}$ ). These rates are comparable to, if a little higher than, published results which report the yearly growth rate of S. variabilis as 0.84 to $1.25 \mathrm{~mm} \mathrm{year}^{-1}$ and a reef accumulation rate of $0.27 \mathrm{~mm} \mathrm{year}^{-1}$ (Fallon et al. 2014). Interestingly, the growth rates of deeper-caught colonies in this latter study tended to be highest (Fallon et al. 2014), and whatever unknown mechanism explains this relationship could contribute to the relatively fast growth rates seen in the current study, as the corals used here were sampled near the maximum depth of the known distribution of $S$. variabilis for the Southwest Pacific region (Bostock et al. 2015).

The effect of seawater $\mathrm{pH}$ on the calcification rate of marine calcifiers is often highly varied. For example, a reduction in seawater $\mathrm{pH}$ has led to reduced calcification rates in sea urchin larvae (Clark et al. 2009), foraminiferans (Moy et al. 2009) and an Arctic mollusc (Comeau, 2009), whilst leading to increased calcification rates in some coccolithophores (Iglesias-Rodriguez et al. 2008; although also see Riebsell et al. 2000) and clams (Waldbusser et al. 2010). Many shallow water corals have shown a decline in calcification when exposed to OA, including the temperate coral Oculina arbuscular (Ries et al. 2009) and reefs of massive Porites species on the Great Barrier Reef, which have shown a 16 -year decline in calcification by as much as $21 \%$, attributed to OA and 
increasing seawater temperatures (De'ath et al. 2012). In contrast, growth rates which are independent of $\mathrm{pH}$ (as seen here) have been found in deep-sea corals, including $M$. oculata (Maier et al. 2013a) and L. pertusa (Form \& Riebsell, 2012; Maier et al. 2013a). However, while M. oculata was not affected when $\mathrm{pH}$ was manipulated to end-ofcentury projections, when the partial pressure of $\mathrm{CO}_{2}$ was reduced to pre-industrial levels, calcification rates in this species increased significantly relative to the control (Maier et al. 2013). This gives us important information about the historical effect of OA on the calcification of deep-sea corals, indicating that the present-day calcification rate of some deep-sea corals has already declined due to an anthropogenic increase in the concentration of atmospheric $\mathrm{CO}_{2}$.

Although no net effect of OA on linear extension was seen in the current study, it is important to note that measurements were only taken after several months, while shorterterm changes might have occurred and hence been undetected. Indeed, research suggests that some deep-sea corals may be able to acclimatise to reductions in $\mathrm{pH}$. Colonies of $L$. pertusa were exposed to a $\mathrm{pH}$ that was reduced by $0.1 \mathrm{pH}$ units relative to ambient levels. After short-term exposure (one week), colonies showed a decline in calcification of between $26-29 \%$, whilst long-term exposure (six months) elicited no effect on calcification (Form \& Riebsell, 2012). Maier et al. (2009) conducted a similar experiment on the same species and also observed a plateau in the reduction of calcification rates after prolonged exposure. It is not yet understood whether this acclimatization to $\mathrm{pH}$ is typical of all deep-sea corals or what the underlying mechanism is, but it is conceivable that the response of $S$. variabilis to OA across time was not consistent; more sampling points would help to resolve this. 
Although linear extension and skeletal density were independent of $\mathrm{pH}$, buoyant weight decreased with greater magnitude in the treatment group; it is assumed that this loss in buoyant weight was due to a greater loss of tissue. A reduction in body mass is a response to environmental stress which is shown by numerous marine species, including the coastal mussel Mytilus californianus when exposed to the projected end-of-century reduction in seawater $\mathrm{pH}$ (Gaylord, 2011). A loss of tissue when exposed to OA conditions has also been observed in tropical corals (e.g. P. damicornis and $O$. patagonica), but their tissues rejuvenated when the corals were returned to ambient $\mathrm{pH}$ (Kvitt et al. 2015). In these latter corals, reduced $\mathrm{pH}$ induced tissue-specific apoptosis, a breakdown of coenosarc and a loss of the colonial form. The tissue loss of S. variabilis seen here could therefore represent the early stages of a similar process. Such a loss of the colonial form, reverting to solitary and non-calcifying polyps, has been proposed as an evolutionary mechanism which has allowed corals to survive through geological periods of unfavourable calcification conditions (Kvitt et al. 2015) and could explain several "reef gaps" in the geological records (Wood, 1999).

Alternatively, the loss of tissue in $S$. variabilis could represent a reallocation of energy. That is, corals in the treatment group may have been diverting energy away from the maintenance of tissues, allowing them to maintain the same growth rates as the control group. For this reason, tissue loss in corals is considered a greater indicator of physiological stress than coral growth (Anthony et al. 2002). However, an organism presumably cannot continue breaking-down tissues to support its growth, as a threshold will ultimately be reached where it becomes seriously compromised. If this were to happen in S. variabilis, then it would cause major changes to its structure and function as an ecosystem engineer on seamounts throughout the Southwest Pacific region (Tracey et al. 2011). 


\subsection{THE IMPACTS OF OA ON THE RESPIRATION RATE OF SOLENOSMILIA VARIABILIS}

This research presents the first measurements of respiration rates in S. variabilis. Respiration rates were highly variable, ranging from $0.065 \mu \mathrm{g} \mathrm{O}_{2} \mathrm{~g}^{-1}$ protein $\mathrm{h}^{-1}$ to 1.178 $\mu \mathrm{g} \mathrm{O}_{2} \mathrm{~g}^{-1}$ protein $\mathrm{h}^{-1}$ at the 6 month time-point (both of which were recorded in control colonies), and $0.234 \mu \mathrm{g} \mathrm{O}_{2} \mathrm{~g}^{-1}$ protein $\mathrm{h}^{-1}$ to $1.755 \mu \mathrm{g} \mathrm{O}_{2} \mathrm{~g}^{-1}$ protein $\mathrm{h}^{-1}$ at the 12 -month time-point (again, both extremes of this range were recorded in control colonies). These respiration rates are comparable to other deep-sea corals. For example, respiration rates range from 0.074 to $0.266 \mu \mathrm{mol} \mathrm{O}_{2}$ (g skeletal dry weight $)^{-1} \mathrm{~h}^{-1}$ and 0.095 to 0.725 $\mu \mathrm{mol} \mathrm{O}_{2}$ (g skeletal dry weight $)^{-1} \mathrm{~h}^{-1}$ for L. pertusa and M. oculata, respectively (Maier et al. 2013).

Respiration rates of $S$. variabilis were not affected by the OA conditions tested here. A similar lack of impact on respiration has been seen in several other invertebrate taxa, including sea cucumbers (Collard et al. 2014) and sea urchins (Stumpp et al. 2012), as well as the shallow-water tropical coral Acropora digitifera, which showed no impact of reduced $\mathrm{pH}$ after five weeks of treatment (Takahashi et al. 2013). Insensitivity of respiration to reduced $\mathrm{pH}$ has also been reported in deep-sea corals. For example, Maier et al. (2013) exposed colonies of a Mediterranean coral, L. pertusa, to varying levels of $\mathrm{pH}$, including end-of-century projections, and found that these did not affect respiration rate. Likewise, the cold-water cup coral Desmophyllum dianthus also showed no change in respiration rate when $\mathrm{pH}$ was reduced by 0.31 units below ambient levels, despite the up-regulation of genes involved in cellular stress and immune defence (Carreiro-Silva et al. 2014). Given this latter finding, it is possible that, while respiration in S. variabilis 
was independent of $\mathrm{pH}$ in the current study, there may have been physiological reconditioning (i.e. an up-regulation of genes) that allowed S.variabilis to maintain its growth and respiration rates under the OA conditions tested here; this requires further study.

While it did not respond to reduced $\mathrm{pH}$, the respiration rate of $S$. variabilis increased with time (from 6 months to 12 months) in both the treatment and control colonies. A similar response was found by Maier et al. (2013) in the deep-sea corals M. oculata and L. pertusa, and was attributed to regular feeding, which may have provided an increased energy supply, sustaining an elevated level of coral metabolism. Regular feeding may also mask the effects of OA in experimental work, as was found by Cohen \& Holcomb (2009), who concluded that the increased energy requirements of calcification in a range of tropical coral species (Astrangia, Oculina, Porites, Montipora and Favia spp.) may be off-set by increased availability of nutrients under laboratory conditions. Due to the natural habitat of $S$. variabilis, it is difficult to predict the amount of nutrient-fall reaching colonies in situ, but my findings highlight the need to know the likely food quantities available to deep-sea corals so that future experiments can more closely mirror their natural environment.

While not seen here, metabolic depression is a response shown by most animal phyla to environmental stress (Guppy \& Withers, 1999). This may be beneficial when changes to external factors mean that basal metabolism requires more energy, or the energy source available to an organism is reduced as a way of conserving energy under stress. Some deep-sea corals have shown metabolic depression when exposed to reduced $\mathrm{pH}$. In particular, Hennige et al. (2014) investigated the short-term metabolic and growth responses of L. pertusa to OA and found that, after 21 days, corals that were exposed to reduced $\mathrm{pH}$ had significantly reduced respiration rates. Metabolic depression in response 
to reduced $\mathrm{pH}$ has also been seen in species of starfish (Asterias rubens) (Collard et al. 2013) and mollusc (Littorina littorea) (Melatunan et al. 2011). It is notable though, that metabolic responses to stress can often be highly variable, even between individuals of the same species. For example, Calosi (2013) investigated the metabolic response of various populations of the same species of polychaete to environmental stress, and observed population-specific phenotypic plasticity, with some populations responding to OA conditions with a depression of metabolism and others showing an increase. The lack of a decline in the respiration rates of $S$. variabilis is perhaps not surprising however, given the increased energetic requirements needed to sustain calcification of this species under the treatment conditions applied here.

\subsection{THE IMPACTS OF OA ON THE pHi OF SOLENOSMILIA}

\section{VARIABILIS}

The pHi of isolated $S$. variabilis cells was not significantly impacted by OA. Indeed, the lowest pHi $(7.67 \pm 0.08)$ was in fact recorded in the control group after nine months. The pHi values recorded here, even under OA conditions, are comparable to, (and sometimes higher than) the pHi of other cnidarian cells. For example, Gibbin and colleagues (Gibbin et al. 2014) reported the pHi of cnidarain cells in the non-symbiotic state, isolated from P. damicornis, as 6.9 to 7.0 under ambient conditions.

The $\mathrm{pHi}$ of isolated $S$. variabilis cells was also not affected by seawater $\mathrm{pH}$ at the levels tested here. This differs from previous work on symbiotic cnidarian cells which found that the pHi of isolated coral cells is higher when the cell is exposed to a reduced ambient pH (Gibbin \& Davy, 2014) and that the photsynthetic mechanism behind this increase in pHi may help prevent cellular acidosis under such conditions (Gibbin \& Davy, 2014). To test this, Gibbin et al. (2014) measured the pHi of cnidarian cells isolated from the 
tropical coral P. damicornis, both in symbiotic and non-symbiotic states, in response to an elevated $\mathrm{CO}_{2}$ treatment, which reduced the $\mathrm{pH}$ of seawater by $1 \mathrm{pH}$ unit, relative to ambient levels. They found that the pHi of coral cells that lacked a symbiont (or where photosynthesis was hindered by darkness or thermal stress) remained largely unchanged, but the pHi in coral cells that contained photosynthetically-active symbionts increased (Gibbin \& Davy 2014; Gibbin et al. 2014). The authors concluded that increased photosynthesis by the dinoflagellate symbiont under elevated $\mathrm{CO}_{2}$ availability countered the impacts of the reduced $\mathrm{pH}_{\mathrm{e}}$ and led to an increased ability of the coral host cell to withstand cellular acidosis. These findings informed the hypothesis for this section of the research: that isolated $S$. variabilis cells (which lack a symbiont) would not increase in response to a reduction in the $\mathrm{pH}$ of seawater, but would instead decline. Contrary to this hypothesis, however, the $\mathrm{pHi}$ of $S$. variabilis cells did not respond to changes in external $\mathrm{pH}$ at the levels tested here, and this could have important implications for the survivability of deep-sea corals under OA in the coming century. Further work is needed to confirm this lack of a response however, and in particular to identify at what $\mathrm{pH}$ the coral might lose its ability to regulate its $\mathrm{pHi}$ through potential mechanisms such as an upregulation of membrane transporters (Kaniewska et al. 2012) and hence buffer against changes in seawater $\mathrm{pH}$.

It is perhaps not surprising that reduced seawater $\mathrm{pH}$ did not affect the $\mathrm{pHi}$ of $S$. variabilis, as the seawater $\mathrm{pH}$ was just 0.23 units below the control. In contrast, treatment levels applied in previous experiments have often included high-end $\mathrm{CO}_{2}$ scenarios to investigate whether there may be a threshold response. For example, Gibbin \& Davy (2014) exposed cells isolated from a tropical species of coral to three different $\mathrm{CO}_{2}$ concentrations: high (corresponding to a decline in $\mathrm{pH}$ of $0.6 \mathrm{pH}$ units relative to the control), intermediate (corresponding to a decline in $\mathrm{pH}$ of 0.31 units) and ambient. The 
pHi of both host coral cells and Symbiodinium cells was measured, though the results obtained from the study of coral cells that did not contain any symbionts are especially relevant here. Of particular note, while some decline in the $\mathrm{pHi}$ of these non-symbiotic coral cells was observed, this change was only observed in the high $\mathrm{CO}_{2}$ treatment and not in the intermediate treatment, consistent with the lack of a response in S. variabilis. Here, given the logistically challenging nature of sampling S. variabilis colonies, a large sample size could not be obtained and for this reason only two $\mathrm{pH}$ treatments were selected. This limits the ability to comment on a potential threshold response and the longer-term impacts of OA on this deep-sea coral. Future research should incorporate a wider range of high $\mathrm{CO}_{2}$ conditions to address these issues, and to better understand the regulatory capacity and mechanisms employed by deep-sea corals to withstand changes in their environmental $\mathrm{pH}$.

\subsection{WHAT IS THE FUTURE FATE OF SOLENOSMILIA VARIABILIS AND OTHER DEEP-SEA CORALS?}

The key objective of this research was to investigate how S. variabilis responds to those reductions in the $\mathrm{pH}$ of seawater that are expected to occur by the end of this century. While many physiological parameters remained unchanged, including $\mathrm{pHi}$, respiration and growth, a significant loss of tissue (estimated from colour) was observed in the treatment group. Although the findings indicate that other physiological parameters of S. variabilis ( $\mathrm{pHi}$, respiration rate and growth rate) are relatively insensitive to these predicted changes in $\mathrm{pH}$ in the short- and medium-term, care must be taken when extrapolating these experimental data to an in situ context. In particular, consideration needs to be given to: thresholds; interactive and multiplicative impacts of the wider environmental changes caused by anthropogenic climate change; and the implications 
of these changes on the wider ecosystem and the species interactions occurring within this. Laboratory experiments, such as the one described here, are often only able to provide a snapshot image of how an organism may respond to an environmental change. Furthermore, the associated results should be interpreted alongside other aspects of the ecosystem, including changes to the behavior of other animals in the ecosystem, changes to sensory ability, and the differing sensitivities of various life-stages.

Importantly, it can be expected that all species within an ecosystem will be impacted by an environmental change. This is of particular importance for habitat providers such as deep-sea corals. Indeed, an example of this can be seen on the shallow reefs of Palau, where natural and localised acidification (which is already as high as end-of-century projections) has led to a 10 -fold increase in bio-erosion from areas of ambient $\mathrm{pH}$ to those areas with a reduced pH (Barkley et al. 2015). Barkley et al. (2015) illustrated how OA changes the physiology of corals, making the impact of bio-erosion greater. Should a similar change in the physiology be observed in S. variabilis, leading to a greater impact from bio-erosion, then this could exacerbate the tissue loss seen here. An organism's sensory abilities may also be impacted by OA, changing the way an organism interacts with other species, as prey, a predator, and or a competitor. For example, while it was originally thought that the mature stages of many fishes were relatively robust to OA (Kikkawa et al. 2004) and the hatchling stage was the most sensitive (Ishimatsu et al. 2004), recent research has revealed that the sensory synapses controlling the olfactory and auditory senses of many fishes are impaired by OA (Munday et al. 2009; Simpson et al. 2011) and fish at this stage of their life-history would be more vulnerable to predation. While there is no research into the impacts of OA on the sensory abilities of corals, it remains an important area of research requiring investigation. An impairment of a coral's ability to detect seasonal biofalls, for instance, could see the failure of 
synchronized spawning, which is thought to be triggered by such events (Burgess, 2002). Such a failure could have a serious impact on the fertilization of gametes and consequential larval settlement.

Each life stage of an organism has a different sensitivity to environmental pressures. While little is known about the reproductive ecology of $S$. variabilis, it is understood that it is a broadcast spawner and gonochoristic (Burgess, 2002; Pires, 2014). There are several different life stages of a sexually reproducing coral, from release of sperm and eggs, fertilisation, development of a zygote, planula larvae, settlement, and eventually colony growth. Each of these life stages may show a different sensitivity to environmental change. This research focussed on the mature stage of the coral colony, but other life-history stages must also be considered as it has been proposed that the early life stages of marine calcifiers, including corals, are the most vulnerable to OA. Laboratory experiments have revealed that OA has a negative impact on the fertilisation, cleavage, larval, settlement and reproductive stages of many marine invertebrates (Kurihara, 2008). Furthermore, Nakamura et al. (2011) found that metamorphosis of the tropical coral A. digitifera was disrupted under OA, which impaired successful recruitment and survivability of subsequent generations and OA had a deleterious impact on sperm motility in this coral (Nakamura \& Morita 2012). Given that different life stages of some corals (Nakamura et al. 2011) and many other marine invertebrates (Kurihara, 2008) show a differing sensitivity to OA, then other life stages of S. variabilis (e.g. larvae, gametes) may show more sensitivity than the mature colony stage used here. 


\subsubsection{What are the different responses to environmental change that may be shown by Solenosmilia variabilis and other deep-sea corals?}

Responses of an organism to an environmental stressor can be broadly categorised into a multiplicative, threshold or a non-linear response. Interactive or multiplicative responses are those where several external pressures (i.e. environmental changes) may interact with one another to have a greater impact on an organism than they would individually (Fig 4.1).

An example of an interactive response scenario that could exist for S. variabilis includes the interaction between seawater stratification and shoaling of the ASH, both of which are predicted results of climate change (IPCC, 2013). The former will reduce the availability of nutrient fall to the deep-sea (IPCC, 2013) and this could exacerbate the impact of the latter, as calcification under the ASH requires more energy (Wood et al. 2008). Stratification of the overlying water column may also have an impact on the synchrony of broadcast spawning, as in S. variabilis this is thought to coincide with the end-of-summer biomass falls (Burgess, 2002).

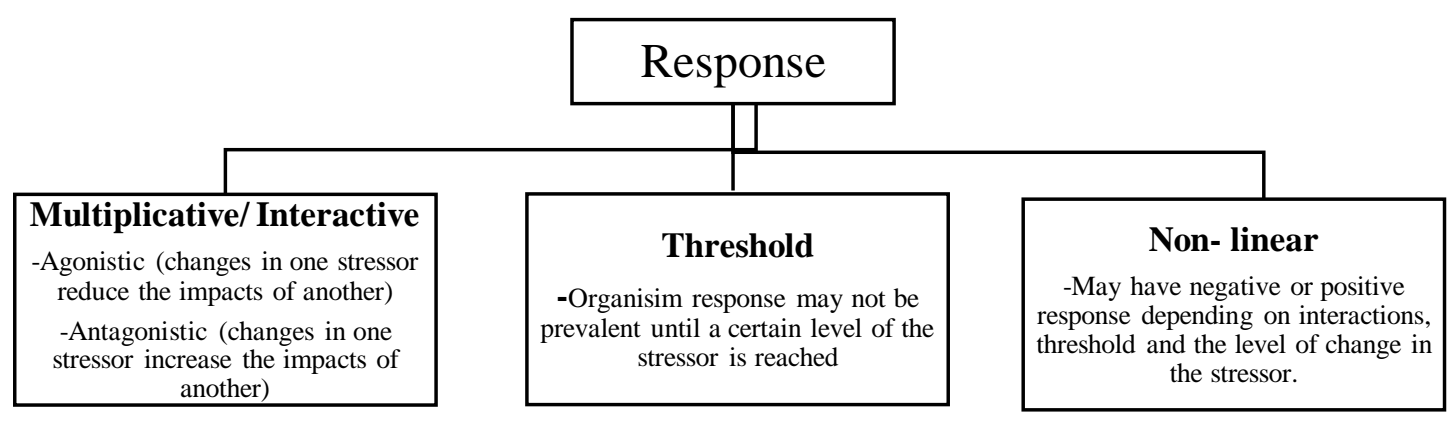

Figure 4.1: The different types of response to an environmental stressor: Multiplicative, threshold or non-linear. 
A threshold can be described as a point that must be exceeded to begin producing an effect on an organism or to elicit a response from that organism. Importantly, until a threshold is reached, it is often hard to predict the magnitude of the response. Given the limited response of $S$. variabilis to OA, it is likely that the treatment level used in this current study did not incorporate the response threshold for S. variabilis, and it cannot be determined what this threshold may be or what the response may be. The conceptual diagram presented in Fig. 4.2 illustrates the possibilities of a threshold or interactive response in S. variabilis. 


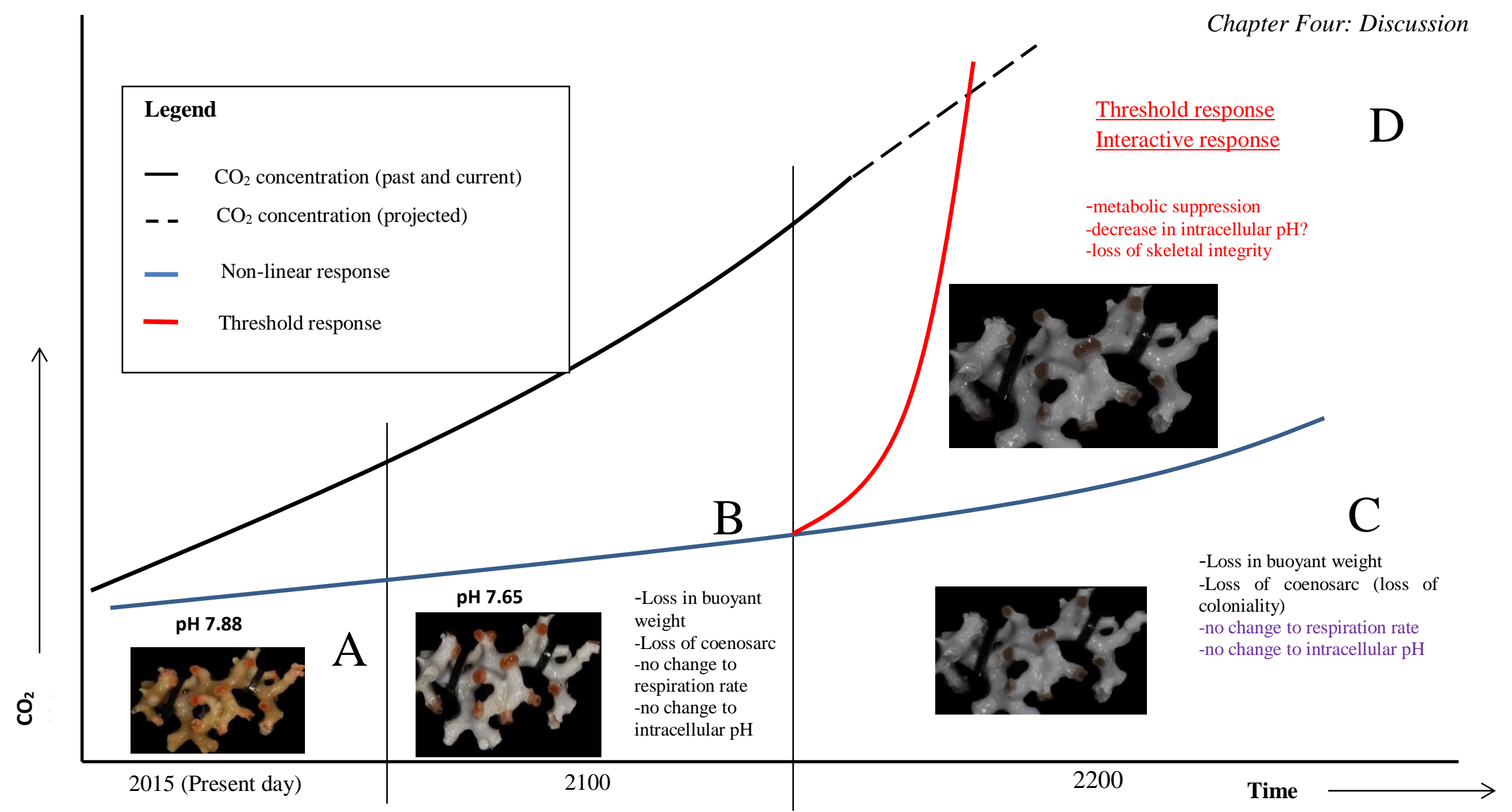

Figure 4.2: The response of the deep-sea coral Solenosmilia variabilis to ocean acidification. This figure shows $S$. variabilis as it is living now (A) and what is expected to happen due to oceanic $\mathrm{pH}$ changes by the end of this century and inferred from this research (B). Both (C) and (D) are projections beyond the scope of this research: (C) indicates what may happen should the current response observed during this research continue (blue line) and (D) indicates what may happen if a threshold response occurs (red-line). A threshold response may initiate metabolic suppression, a decrease in intracellular $\mathrm{pH}$ and a loss of skeletal integrity. 


\subsubsection{Can Solenosmilia variabilis and other deep-sea corals adapt to ocean acidification?}

Adaptation exists as two main types: genetic adaptation (i.e. evolutionary response) or acclimatisation (i.e. phenotypic plasticity). There are several variables which determine how a species responds to environmental change, including the gene-pool of the population experiencing environmental change and the rate of environmental change, relative to the generational time of that species. Many deep-sea species are slow-growing and long-lived (Cairns, 1979), with a long generation time, and this has a large impact on the ability of deep-sea species to adapt to environmental change.

The environmental history of a species can influence the adaptive ability of that species. Populations, such as those found in coastal environments, experiencing frequent disturbances and a high variability within their natural environment, typically have a higher genetic diversity and greater adaptability (Hunter, 1993). How a population's evolutionary environmental history can influence the adaptability of that population is illustrated through the work carried out by Pivotto et al. (2015). Pivotto and colleagues investigated the diversity of thermotolerance within individuals of the same species, using the octocoral Eunicella cavolini. They found a highly contrasted response to temperature which varied along a depth gradient, with individuals sampled from a shallow depth ( $20 \mathrm{~m}$ deep, with a greater variation in temperature) having a greater thermotolerance than those sampled from a deeper depth $(\sim 40 \mathrm{~m}$ deep, with a lesser variation in temperature). S. variabilis, being a deep-sea species, has evolved in a stable environment which does not receive the same cyclic fluctuations as shallow water environments and this means that it may have lower genetic variability. A low genetic variability, alongside a long generational time, is likely to limit the ability of $S$. variabilis, and other deep-sea corals, to adapt to OA. 
Despite the apparent inability to adapt to OA conditions, some deep-sea corals, including S. variabilis, have been discovered to thrive below the present-day ASH (which ranges from $800-1200$ m; Bostock et al. 2015). There is a well-defined peak in the depth range of S. variabilis in the South Pacific region, with $85 \%$ of reported occurrences between $800 \mathrm{~m}$ and $1400 \mathrm{~m}$, at an average depth of $1000 \mathrm{~m}$ (Bostock et al. 2015). An explanation for the unexpectedly large number of deep-sea corals living just below the current ASH could be their slow growth rates and the comparatively fast shoaling of the $\mathrm{ASH}$, which has undergone an upward migration of 1-2 metres per year over the last 20 years (Feely et al. 2012). As described by Bostock et al. (2015), a coral which first established 100 years ago may have started growing just above the ASH, but now sits between 100 - 200 m below the modern ASH.

The colonies obtained for this research were sampled at depths ranging from 1220 to $1370 \mathrm{~m}$ (Table 2.1). This depth range is approaching the maximum depth of distribution for the majority of $S$. variabilis colonies in the South Pacific region and exceeds the majority depth distribution of other known species in this region (Tracey et al. 2011). Studies of species at the extremes of their distribution highlight the limits of that species' adaptive range. Because the corals used in this research have been sampled from a depth which may be approaching the limit of their known distribution, they may exhibit greater resilience to the undersaturated water below the ASH and may have already been exposed to such water due to a post-industrial shoaling of the ASH. Indeed, this could have contributed to the limited response to OA seen here.

The discovery of corals living and thriving below the ASH is indicative that they have physiological mechanisms that allow them to continue to calcify, even in reduced $\mathrm{pH}$ and reduced $\Omega$ Ar conditions. Such a mechanism could be the ability to increase the $\mathrm{pH}$ 
of internal calcifying fluid, illustrated by high boron isotope levels $(\delta 11 \mathrm{~B})$ in several species of deep-sea corals (McCulloch et al. 2012). Such a strategy could explain the occurrence of calcifying cup corals well below the ASH in several global locations (Miller et al. 2011; Thresher et al. 2011).

This research into the physiological response of $S$. variabilis to OA indicates an insensitivity of calcification and growth to such conditions. As coral samples were sampled close to the ASH, they could have already been exposed to reduced $\Omega \mathrm{Ar}$ conditions due to a shoaling of the ASH to $<750 \mathrm{~m}$ during the austral summer in this region (Bostock et al. 2015). If so, the colonies used here may have previously employed mechanisms to allow continued calcification under conditions of reduced aragonite saturation. Still, while there appeared to be a limited response at the organismal level, a response could have been initiated at the gene expression level. For instance, during an eight-month OA exposure experiment on the cup coral $D$. dianthus, no significant differences were detected among respiration and calcification rates, but significant differences were detected at the gene expression level, with an up-regulation of genes involved in cellular stress and immune defenses (Carreiro-Silva et al. 2014). It remains to be seen whether generational-time limits the adaptive potential for many deep-sea populations.

\subsubsection{Can Solenosmilia variabilis and other deep-sea corals migrate to a refuge?}

Given that genetic adaptation by S. variabilis and other deep-sea corals may be limited by generational-time and environmental-history-derived genetic variability, the ability of deep-sea corals to persist in the face OA may be dependent on their ability to disperse into shallower habitats as the ASH rises. By 2099, while impacted by OA, the summits 
and flanks of seamounts in the North Atlantic and waters surrounding New Zealand will provide more suitable habitat than the surrounding seafloor (Tittensor et al. 2010). It has been suggested that these locations may serve as a temporary refuge for scleractinian corals within these regions (Tittensor et al. 2010), and dispersal of larvae to these summits and flanks will provide a habitat where deep-sea corals can continue to thrive above the ASH. However, genetic studies have uncovered important isolating mechanisms for the populations of deep-sea corals on seamounts within several regions worldwide. Genetic analysis of the scleractinian cup coral D. dianthus, for example, revealed genetic isolation and limited gene flow between populations in SE Australia, Chile and New Zealand, with limited gene-flow being more pronounced between different depths, even for corals found on the same seamount (Miller et al. 2011). These authors predicted that the likely cause of this genetic isolation was the stratification of water at these depths, due to the different temperatures and salinities of the water bodies that circulate through those regions sampled. Apparent genetic isolation suggests that corals cannot disperse new recruits to avoid the unfavourable conditions associated with a shoaling of the ASH.

\subsection{FUTURE WORK FOR OA RESEARCH ON SOLENOSMILIA VARIABILIS AND OTHER DEEP-SEA CORALS}

The work presented in this thesis provides an important first step towards discovering the impacts of OA on an ecologically significant species of deep-sea coral from New

Zealand. Results indicated an apparent insensitivity of respiration, growth and pHi to OA. As discussed throughout this chapter however, there is a need for future OA studies, on $S$. variabilis and other deep-sea corals, to incorporate other in situ factors. Specifically, future research should consider inter-species interactions, multiple 
stressors, and whether or not various life-history stages respond differently to environmental change.

Of particular interest are the corals that currently sit below the ASH (Bostock et al. 2015). It is likely that these corals have some mechanism that allows them to thrive and continue calcifying at this depth. Understanding the physiology of these populations, and whether they differ from populations that sit above the ASH, could help researchers to better understand the mechanisms that have allowed these corals to survive and continue to calcify in an environment that would otherwise not be expected to support calcification.

There is also a need to understand the deep-sea environment and the mechanics of this much more, so that experiments can mirror this more closely. Of particular importance is an understanding of the amount and rate of food reaching the depths where deep-sea corals are typically found as well as their dietary components. Moreover, the role of pressure and how this may impact upon an organism's response to environmental change (and specifically OA) is important to consider. Indeed, pressure impacts physiological regulatory mechanisms in a number of marine species (Bell, 2012). Typically, a destabilization of hydrogen bonds occurs as a result of pressure changes, and stacking interactions between cells are lost or hindered in deep-sea species with reduced pressure (Bell, 2012). While highly motile species will have mechanisms that allow them to cope with these effects of pressure change as they move vertically through the water column (Childress \& Thuesen, 1993), deep-sea corals are sedentary and hence may be more sensitive to pressure differences, such as those encountered when they are brought to the surface for experimental purposes. Nevertheless, basic laboratory experiments can still 
further our knowledge in terms of providing comparative data and trends, even if the absolute values are potentially compromised.

\subsection{CONCLUSION}

This research aimed to investigate the physiological response of an ecologically important and protected species of deep-sea coral, S. variabilis, to OA. Specifically, the research aimed to investigate the response of several key physiological parameters to OA, including: pHi, growth, health and respiration rate. This research did not set out to explore a threshold response and instead applied an ecologically relevant scenario. The level of the reduced $\mathrm{pH}$ treatment was $\mathrm{pH} 7.65$, and the control was $\mathrm{pH} 7.88$, reflecting end-of-century projections for a reduction in the $\mathrm{pH}$ of seawater at the depth from which the corals were sampled (IPCC, 2013).

My results show that the pHi of isolated $S$. variabilis cells is independent of external seawater $\mathrm{pH}$, at least in the context of end-of-century predictions. Similarly, respiration is insensitive to reduced $\mathrm{pH}$, and there were no detectable difference in growth rate or form, between treatment and control colonies. While the findings of this research point towards insensitivity at the organismal level, tissue loss occurred in response to OA. This could indicate a reallocation of energy and points towards phenotypic plasticity, supporting a growing hypothesis that corals can alternate between soft-bodied and fossilizing forms, something that has enabled corals to survive past periods of environmental stress. This however, requires experimental confirmation.

This was the first instance of an investigation of OA impacts on deep-sea coral in New Zealand waters and many questions and subsequent recommendations have arisen from the research results. Given that deep-sea corals provide important habitat complexity and support a large biodiversity, and that $S$. variabilis is the most common scleractinian 
deep-sea coral in the Southwest Pacific, the response of $S$. variabilis to OA at both and individual and ecosystem levels remains an important area of research. 


\section{References}


Al-Horani, F., Al-Moghrabi, S. \& De Beer, D. (2003). The mechanism of calcification and its relation to photosynthesis and respiration in the scleractinian coral Galaxea fascicularis. Marine Biology, 142: 419-426.

Akimzhanov, A. M. \& Boehning, D. (2011). Monitoring dynamic changes in mitochondrial calcium levels during apoptosis using a genetically encoded calcium sensor. Journal of Visualized Experiments, 50. DOI: 10.3791/2579

Almany, G. R. (2004). Differential effects of habitat complexity, predators and competitors on abundance of juvenile and adult coral reef fishes. Oecologia, 141: 105-113.

Andersson, A. J., Bates, N. R. \& Mackenzie, F. T. (2007). Dissolution of carbonate sediments under rising $\mathrm{pCO}_{2}$ and ocean acidification: observations from Devil's Hole, Bermuda. Aquatic Geochemistry, 13: 237-264.

Andersson, A., Mackenzie, F. \& Bates, N. (2008). Life on the margin: implications of ocean acidification on $\mathrm{Mg}$-calcite, high latitude and cold-water marine calcifiers. Marine Ecology Progress Series, 373: 265-273.

Anthony, K., Connolly, S. R. \& Willis, B. L. (2002). Comparative analysis of energy allocation to tissue and skeletal growth in corals. Limnology and oceanography, 47: 1417-1429.

Baillon, S., Hamel, J. F., Wareham, V. E. \& Mercier, A. (2012). Deep cold-water corals as nurseries for fish larvae. Frontiers in Ecology and the Environment, 10: 351-356.

Barkley H. C., Cohen A. L., Golbuu Y., Starczak V. R., DeCarlo T. M. \& Shamberger K. E. F. (2015). Changes in coral reef communities across a natural gradient in seawater $\mathrm{pH}$. Science Advances. DOI: $10.1126 /$ sciadv. 1500328.

Bell, E. (2012). Life at extremes: Environments, organisms, and strategies for survival (Vol. 1). Massachusetts, Cambridge (USA): CABI.

Bostock, H.C., Tracey, D.M., Currie, K.I., Dunbar, G.B., Handler, M.R., Mikaloff Fletcher, S.E., Smith, A.M. \& Williams, M.J.M. (2015). The carbonate mineralogy and distribution of habitat-forming deep-sea corals in the Southwest Pacific region, Deep-Sea Research Part I: Oceanographic Research Papers, 100: 88-104.

Bradford, M. M. (1976). A rapid and sensitive method for the quantitation of microgram quantities of protein utilizing the principle of protein-dye binding. Analytical biochemistry, 72: 248-254.

Buhl-Mortensen., L. \& Mortensen., P. (2005). Distribution and diversity of species associated with deep-sea gorgonian corals off Atlantic, Canada. Cold-water corals and ecosystems, 1: 849-879.

Burgess, S. N. (2002). Environmental and Ecological Aspects of Deep-sea Scleractinians in the New Zealand Region (Doctoral dissertation, Marine and Environmental Science: University of Auckland).

Cairns, S. D. (1979). The deep-water Scleractinia of the Caribbean Sea and adjacent waters. Studies on the Fauna of Curaçao and other Caribbean Islands, 57: 1-341.

Cairns, S. D. (2007). Deep-water corals: an overview with special reference to diversity and distribution of deep-water scleractinian corals. Bulletin of marine Science, 81: 311-322. 
Cairns, S.D. (1995). The Marine Fauna of New Zealand: Scleractinian (Cnidaria: Anthozoa). New Zealand Oceanographic Institute Memoir 103, 210 pp.

Calosi, P., Rastrick, S. P., Lombardi, C., de Guzman, H. J., Davidson, L., Jahnke, M. \& Gambi, M. C. (2013). Adaptation and acclimatization to ocean acidification in marine ectotherms: an in situ transplant experiment with polychaetes at a shallow $\mathrm{CO}_{2}$ vent system. Philosophical Transactions of the Royal Society of London: Biological Sciences, 368. DOI: 10.1098/rstb.2012.0444

Canadell, J., Le Quéré, C., Raupach, M., Field, C., Buitenhuis, E., Ciais, P. \& Marland, G. (2007). Contributions to accelerating atmospheric $\mathrm{CO}_{2}$ growth from economic activity, carbon intensity, and efficiency of natural sinks. Proceedings of the national academy of sciences, 104: 18866-18870.

Cao, L., Zhang, H., Zheng, M. \& Wang, S. (2014). Response of ocean acidification to a gradual increase and decrease of atmospheric $\mathrm{CO}_{2}$. Environmental Research Letters, 9:1-9.

Carreiro-Silva, M., Cerqueira, T., Godinho, A., Caetano, M., Santos, R. S. \& Bettencourt, R. (2014). Molecular mechanisms underlying the physiological responses of the cold-water coral Desmophyllum dianthus to ocean acidification. Coral reefs, 33: 465-476.

Casey, J. R., Grinstein, S. \& Orlowski, J. (2010). Sensors and regulators of intracellular pH. Nature reviews: Molecular cell biology, 11: 50-61.

Childress, J. J. \& Thuesen, E. V. (1993). Effects of hydrostatic pressure on metabolic rates of six species of deep-sea gelatinous zooplankton. Limnology and oceanography, 38: 665-670.

Church, J. A. \& White, N. J. (2006). A 20th century acceleration in global sea-level rise. Geophysical research letters, 33. DOI: 10.1029/2005GL024826.

Clark, D., Lamare, M. \& Barker, M. (2009). Response of sea urchin pluteus larvae (Echinodermata: Echinoidea) to reduced seawater $\mathrm{pH}$ : a comparison among a tropical, temperate, and a polar species. Marine biology, 156: 1125-1137.

Clark, M. R. \& Rowden, A. A. (2009). Effect of deepwater trawling on the macro-invertebrate assemblages of seamounts on the Chatham Rise, New Zealand. Deep Sea Research Part I: Oceanographic Research Papers, 56: 1540-1554.

Clark, M.R., Anderson, O., Bowden, D., Chin, C., George, S., Glasgow, D., Guinotte, J., Hererra, S., Osterhage, D., Pallentin, A., Parker, S., Rowden, A.A., Rowley, S., Stewart, R., Tracey, D., Wood, S. \& Zeng, C. (2015). Vulnerable Marine Ecosystems of the Louisville Seamount Chain: voyage report of a survey to evaluate the efficacy of preliminary habitat suitability models. New Zealand Aquatic Environment and Biodiversity Report No. 149. 86 p.

Cohen, A. L. \& Holcomb, M. (2009). Why corals care about ocean acidification: uncovering the mechanism. Oceanography: special issue feature, 22: $118-127$.

Collard, M., Catarino, A. I., Bonnet, S., Flammang, P. \& Dubois, P. (2013). Effects of $\mathrm{CO}_{2}$-induced ocean acidification on physiological and mechanical properties of the starfish Asterias rubens. Journal of experimental marine biology and ecology, 446, 355-362. 
Collard, M., Eeckhaut, I., Dehairs, F. \& Dubois, P. (2014). Acid-base physiology response to ocean acidification of two ecologically and economically important holothuroids from contrasting habitats, Holothuria scabra and Holothuria parva. Environmental Science and Pollution Research, 21: 13602-13614.

Comeau, S., Gorsky, G., Jeffree, R., Teyssié, J. L. \& Gattuso, J. P. (2009). Impact of ocean acidification on a key Arctic pelagic mollusc (Limacina helicina). Biogeosciences, 6: 1877-1882.

Consalvey, M., MacKay, K. \& Tracey, D. (2006). Information review for protected deep-sea coral species in the New Zealand region. Wellington: National Institute of Water and Atmospheric Research Ltd.

Davies, A. J. \& Guinotte, J. M. (2011). Global habitat suitability for framework-forming cold-water corals. PLoS One, 6. DOI: 10.1371/journal.pone.001848.

De'ath, G., Fabricius, K. E., Sweatman, H. \& Puotinen, M. (2012). The 27-year decline of coral cover on the Great Barrier Reef and its causes.Proceedings of the National Academy of Sciences, 109: 17995-17999.

Duineveld, G. C. A., Lavaleye, M. S. S. \& Berghuis, E. M. (2004). Particle flux and food supply to a seamount cold-water coral community (Galicia Bank, NW Spain). Marine Ecology Progress Series, 277: 13-23.

Fabricius, K. E., Langdon, C., Uthicke, S., Humphrey, C., Noonan, S., De'ath, G. \& Lough, J. M. (2011). Losers and winners in coral reefs acclimatized to elevated carbon dioxide concentrations. Nature Climate Change, 1:165-169.

Fabry, V.J., Seibel, B.A., Feely, R.A. \& Orr, J.C. (2008). Impacts of ocean acidification on marine Fauna and ecosystem processes. Journal of Marine Science, 65: 414-32.

Fallon, S., Thresher, R. \& Adkins, J. (2014). Age and growth of the cold-water scleractinian Solenosmilia variabilis and its reef on SW Pacific seamounts. Coral Reefs, 33: 31-38.

Feely, R. A., Sabine, C. L., Lee, K., Millero, F. J., Lamb, M. F., Greeley, D. \& Wong, C. S. (2002). In situ calcium carbonate dissolution in the Pacific Ocean. Global Biogeochemical Cycles, 16: 119.

Feely, R., Sabine, C., Lee, K., Berelson, W., Kleypas, J., Fabry, V. \& Millero, F. (2004). Impact of anthropogenic $\mathrm{CO}_{2}$ on the $\mathrm{CaCO}_{3}$ system in the oceans. Science, 305: 362-366.

Feely, R., Sabine, C., Byrne, R., Millero, F., Dickson, A., Wanninkhof, R. \& Greeley, D. (2012). Decadal changes in the aragonite and calcite saturation state of the Pacific Ocean. Global Biogeochemical Cycles, 26. DOI: 10.1029/2011GB004157.

Fernández-Reiriz, M. J., Range, P., Álvarez-Salgado, X. A., Espinosa, J. \& Labarta, U. (2012). Tolerance of juvenile Mytilus galloprovincialis to experimental seawater acidification. Marine Ecology Progress Series, 454: 65-74.

Ferrari, M. C., Wisenden, B. D. \& Chivers, D. P. (2010). Chemical ecology of predator-prey interactions in aquatic ecosystems: a review and prospectus. Canadian Journal of Zoology, 88: 698-724. 
Fine, M. \& Tchernov, D. (2007). Scleractinian coral species survive and recover from decalcification. Science, 315: 1811-1811.

Form, A. U. \& Riebesell, U. (2012). Acclimation to ocean acidification during long-term $\mathrm{CO}_{2}$ exposure in the cold-water coral Lophelia pertusa. Global Change Biology, 18: 843-853.

Freiwald A,. Fosså J. H., Grehan A., Koslow J. A. \& Roberts J. M. (2004). Cold-water coral reefs: out of sight no longer out of mind. United Nations Environment Programme - World Conservation Monitoring Centre, Cambridge.

Freiwald, A., Fosså, J. H., Grehan, A., Koslow, T. \& Roberts, J. M. (2004). Cold-water coral reefs. UNEP-WCMC, Cambridge, UK.

Friedrich, T., Timmermann, A., Abe-Ouchi, N., Bates, M., Chikamoto, M., Church, J., Dore, D., Gledhill, M., Gonzalez-Davila, M., Heinemann, T., Ilyina, J., Jungclaus, E., McLeod, A. \& Santana-Casiano, J.M. (2012). Detecting regional anthropogenic trends in ocean acidification against natural Variability. Natural Climate Change, 2: 167-171.

Gattuso, J. P. \& Hansson, L. (Eds.). (2011). Ocean acidification. Oxford, UK: Oxford University Press.

Gattuso, J. P., Allemand, D. \& Frankignoulle, M. (1999). Photosynthesis and calcification at cellular, organismal and community levels in coral reefs: a review on interactions and control by carbonate chemistry. American Zoologist, 39:160-183.

Gaylord, B., Hill, T. M., Sanford, E., Lenz, E. A., Jacobs, L. A., Sato, K. N. \& Hettinger, A. (2011). Functional impacts of ocean acidification in an ecologically critical foundation species. Journal of Experimental Biology, 214: 2586-2594.

Gehlen, M., Séférian, R., Jones, D. O., Roy, T., Roth, R., Barry, J. \& Joos, F. (2014). Projected pH reductions by 2100 might put deep North Atlantic biodiversity at risk. Biogeosciences, 11: 6955-6967.

Gibbin, E. M. \& Davy, S. K. (2013). Intracellular pH of symbiotic dinoflagellates. Coral reefs, 32: 859863

Gibbin, E. M., Putnam, H. M., Davy, S. K. \& Gates, R. D. (2014). Intracellular pH and its response to $\mathrm{CO}_{2}$-driven seawater acidification in symbiotic versus non-symbiotic coral cells. The Journal of experimental biology, 217: 1963-1969.

Gibbin, E. M., Putnam, H. M., Gates, R. D., Nitschke, M. R. \& Davy, S. K. (2015). Species-specific differences in thermal tolerance may define susceptibility to intracellular acidosis in reef corals. Marine Biology, 162: 717-723.

Glover, A. G. \& Smith, C. R. (2003). The deep-sea floor ecosystem: current status and prospects of anthropogenic change by the year 2025. Environmental Conservation, 30: 219-241.

Guinotte, J., Orr J., Cairns S., Freiwald, A., Morgan, L. \& George R. (2006). Will human-induced changes in seawater chemistry alter the distribution of deep-sea scleractinian corals? Frontiers in Ecology and the Environment, 4: 141-146.

Guinotte, J.M., Davies, A.J. (2014). Predicted deep-sea coral habitat suitability for the U.S East Coast. PloS One, 9 DOI: 10.1371/journal.pone.0093918 
Guppy, M. \& Withers, P. (1999). Metabolic depression in animals: physiological perspectives and biochemical generalizations. Biological Reviews of the Cambridge Philosophical Society, 74: $1-40$.

Hain, S., Corcoran, E., Hourigan, M., Martin, K. \& Vierros, M. (2004). The status of the cold-water coral reefs of the world. Status of coral reefs of the world, 1: 115-135.

Hansen, J., Johnson, D., Lacis, A., Lebedeff, S., Lee, P., Rind, D. \& Russell, G. (1981). Climate impact of increasing atmospheric carbon dioxide. Science, 213: 957-966.

Hennige, S. J., Wicks, L. C., Kamenos, N. A., Bakker, D. C. E., Findlay, H. S., Dumousseaud, C. \& Roberts, J. M. (2014). Short-term metabolic and growth responses of the cold-water coral Lophelia pertusa to ocean acidification. Deep Sea Research Part II: Topical Studies in Oceanography, 99, 27-35.

Hoegh-Guldberg, O., Mumby, P. J., Hooten, A. J., Steneck, R. S., Greenfield, P., Gomez, E. \& Hatziolos, M. E. (2007). Coral reefs under rapid climate change and ocean acidification. Science, 318: 1737-1742.

Hofmann, G. E., Barry, J. P., Edmunds, P. J., Gates, R. D., Hutchins, D. A., Klinger, T. \& Sewell, M. A. (2010). The effect of ocean acidification on calcifying organisms in marine ecosystems: an organism-to-ecosystem perspective. Annual Review of Ecology, Evolution, and Systematics, 41: 127-147.

Hofmann, L. C., Straub, S. \& Bischof, K. (2013). Elevated $\mathrm{CO}_{2}$ levels affect the activity of nitrate reductase and carbonic anhydrase in the calcifying rhodophyte Corallina officinalis. Journal of Experimental Biology: 64, 899-908.

Hotspot Ecosystem Research and Man's impact on European Seas (HERMIONE). (2012). Report on decreasing seawater $\mathrm{pH}$ effects on coral growth as assessed from experiments. Jacobs University Bremen and Univeristy of the Azores.

Howard, W. R., Havenhand, J., Parker, L., Raftos, D., Ross, P., Williamson, J. \& Matear, R. (2009). Ocean acidification in a Marine Environment: Climate Change Impacts and Adaptation Report Card for Australia 2009. Townsville, Australia: NCCARF Publication. ISBN 978-1921609-03-9.

Hughes, T. P., Baird, A. H., Bellwood, D. R., Card, M., Connolly, S. R., Folke, C. \& Roughgarden, J. (2003). Climate change, human impacts, and the resilience of coral reefs. Science, 301: 929933.

Hunter, C. L. (1993). Genotypic variation and clonal structure in coral populations with different disturbance histories. Evolution, 12: 1213-1228.

Iglesias-Rodriguez, M. D., Halloran, P. R., Rickaby, R. E., Hall, I. R., Colmenero-Hidalgo, E., Gittins, J. R. \& Rehm, E. (2008). Phytoplankton calcification in a high- $\mathrm{CO}_{2}$ world. Science, 320: 336340 .

Ishimatsu, A., Kikkawa, T., Hayashi, M., Lee, K. S. \& Kita, J. (2004). Effects of $\mathrm{CO}_{2}$ on marine fish: larvae and adults. Journal of oceanography, 60: 731-741. 
Johannes, R. E. \& Wiebe, W. J. (1970). Method for determination of coral tissue biomass and composition. Limnology and Oceanography, 15: 822-824

Jokiel, P. L. (2013). Coral reef calcification: carbonate, bicarbonate and proton flux under conditions of increasing ocean acidification. Proceedings of the Royal Society of London B: Biological Sciences, 280: 20130031.

Kaniewska, P., Campbell, P. R., Kline, D. I., Rodriguez-Lanetty, M., Miller, D. J., Dove, S. \& HoeghGuldberg, O. (2012). Major cellular and physiological impacts of ocean acidification on a reef building coral. PloS one, 7: e34659.

Kanwisher, J. W. \& Wainwright, S. A. (1967). Oxygen balance in some reef corals. The Biological Bulletin, 133(2), 378-390.

Kikkawa, T., Kita, J. \& Ishimatsu, A. (2004). Comparison of the lethal effect of $\mathrm{CO}_{2}$ and acidification on red sea bream (Pagrus major) during the early developmental stages. Marine Pollution Bulletin, 48: 108-110.

Kleypas, J., Buddemeier, R., Archer, D., Gattuso, J-P., Langdonc, C. \& Opdyke, B. (1999). Geochemical consequences of increased atmospheric carbon dioxide on coral reefs. Science, 284: 118- 120.

Koslow, J., Gowlett-Holmes, K., Lowry, J., O’Hara, T., Poore, G. \& Williams A. (2001). Seamount benthic macrofauna off southern Tasmania: community structure and impacts of trawling. Marine Ecology Progress Series, 213: 111-125.

Kroeker, K. J., Sanford, E., Jellison, B. M. \& Gaylord, B. (2014). Predicting the effects of ocean acidification on predator-prey interactions: A conceptual framework based on coastal molluscs. The Biological Bulletin, 226: 211-222.

Kurihara, H. (2008). Effects of $\mathrm{CO}_{2}$-driven ocean acidification on the early developmental stages of invertebrates. Marine Ecology Progress Series, 373: 275-284.

Kvitt, H., Kramarsky-Winter, E., Maor-Landaw, K., Zandbank, K., Kushmaro, A., Rosenfeld, H. \& Tchernov, D. (2015). Breakdown of coral colonial form under reduced $\mathrm{pH}$ conditions is initiated in polyps and mediated through apoptosis. Proceedings of the National Academy of Sciences, 112: 2082-2086.

Langdon, C., Takahashi, T., Sweeney, C., Chipman, D., Goddard, J., Marubini, F. \& Atkinson, M. J. (2000). Effect of calcium carbonate saturation state on the calcification rate of an experimental coral reef. Global Biogeochemical Cycles, 14: 639-654.

Lowenstam, H. A. \& Weiner, S. (1989). On biomineralization. Oxford, UK: Oxford University Press.

Lunden, J.J.; Turner, J.M.; McNicholl, C.G.; Glynn, C.K.; Cordes, E.E. (2014). Design, development, and implementation of recirculating aquaria for maintenance and experimentation of deep-sea corals and associated fauna. Limnology and Oceanography Methods, 12: 363-372

Madshus, I. H. (1988). Regulation of intracellular pH in eukaryotic cells. Biochemical Journal, 250: 18. 
Maier, C., Hegeman, J., Weinbauer, M. G. \& Gattuso, J. P. (2009). Calcification of the cold-water coral Lophelia pertusa, under ambient and reduced pH. Biogeosciences, 6: 1671-1680.

Maier, C., Watremez, P., Taviani, M., Weinbauer, M. G. \& Gattuso, J. P. (2012). Calcification rates and the effect of ocean acidification on Mediterranean cold-water corals. Proceedings of the Royal Society of London B: Biological Sciences, 279: 1716-1723.

Maier, C., Bils, F., Weinbauer, M. G., Watremez, P., Peck, M. A. \& Gattuso, J. P. (2013a). Respiration of Mediterranean cold-water corals is not affected by ocean acidification as projected for the end of the century. Biogeosciences, 10: 5671-5680.

Maier, C., Schubert, A., Sànchez, M. M. B., Weinbauer, M. G., Watremez, P. \& Gattuso, J. P. (2013b). End of the century $\mathrm{pCO}_{2}$ levels do not impact calcification in Mediterranean cold-water corals. PLoS One, 8(4): e62655.

McCulloch, M., Trotter, J., Montagna, P., Falter, J., Dunbar, R., Freiwald, A. \& Taviani, M. (2012). Resilience of cold-water scleractinian corals to ocean acidification: Boron isotopic systematics of $\mathrm{pH}$ and saturation state up-regulation. Geochimica et Cosmochimica Acta, 87: 21-34.

McGraw, C., M., Cornwall, C., E., Reid, M., R., Currie, K., I., Hepburn, C., D., Boyd, P., Hurd, C., L. \& Hunter, A., K. (2010). An automated pH-controlled culture system for laboratory-based ocean acidification experiments. Limnology and Oceanography: Methods, 8: 686-694.

Melatunan, S., Calosi, P., Rundle, S. D., Moody, A. J. \& Widdicombe, S. (2011). Exposure to elevated temperature and $\mathrm{pCO}_{2}$ reduces respiration rate and energy status in the periwinkle Littorina littorea. Physiological and Biochemical Zoology, 84: 583-594.

Michaelidis, B., Ouzounis, C., Paleras, A. \& Pörtner, H. O. (2005). Effects of long-term moderate hypercapnia on acid-base balance and growth rate in marine mussels Mytilus galloprovincialis. Marine Ecology Progress Series, 293(2): 109-118.

Miller, K. J., Rowden, A. A., Williams, A. \& Häussermann, V. (2011). Out of their depth? Isolated deep populations of the cosmopolitan coral Desmophyllum dianthus may be highly vulnerable to environmental change. PLoS One, 6(5): e19004.

Morse, J. W. \& Mackenzie, F. T. (1990). Geochemistry of sedimentary carbonates. Developments in sedimentology, 48: 22-33.

Movilla, J., Gori, A., Calvo, E., Orejas, C., López-Sanz, À., Domínguez-Carrió, C. \& Pelejero, C. (2013). Resistance of two Mediterranean cold-water coral species to low-pH conditions. Water, 6: 59-67.

Moy, AD., Howard, WR., Bray, SG. \& Trull, TW. (2009), Reduced calcification in modern Southern Ocean planktonic foraminifera. Nature Geoscience, 2: 276-280.

Munday, P. L., Dixson, D. L., Donelson, J. M., Jones, G. P., Pratchett, M. S., Devitsina, G. V. \& Døving, K. B. (2009). Ocean acidification impairs olfactory discrimination and homing ability of a marine fish. Proceedings of the National Academy of Sciences, 106: 1848-1852.

Nakamura, M. \& Morita, M. (2012). Sperm motility of the scleractinian coral Acropora digitifera under preindustrial, current, and predicted ocean acidification regimes. Aquatic Biology, 15: 299-302. 
Nakamura, M., Ohki, S., Suzuki, A. \& Sakai, K. (2011). Coral larvae under ocean acidification: survival, metabolism, and metamorphosis. PLoS One, 6: e14521-e14521.

Orr, J. C., Fabry, V. J., Aumont, O., Bopp, L., Doney, S. C., Feely, R. A. \& Yool, A. (2005). Anthropogenic ocean acidification over the twenty-first century and its impact on calcifying organisms. Nature, 437: 681-686.

Parmesan, C. \& Yohe, G. (2003). A globally coherent fingerprint of climate change impacts across natural systems. Nature, 421: 37-42.

Pearson, P. N. \& Palmer, M. R. (2000). Atmospheric carbon dioxide concentrations over the past 60 million years. Nature, 406: 695-699.

Pivotto, I. D., Nerini, D., Masmoudi, M., Kara, H., Chaoui, L. \& Aurelle, D. (2015). Highly contrasted responses of Mediterranean octocorals to climate change along a depth gradient. Royal Society of Open Science, 2: e140493.

Pörtner, H. O., Langenbuch, M. \& Reipschläger, A. (2004). Biological impact of elevated ocean $\mathrm{CO}_{2}$ concentrations: lessons from animal physiology and earth history. Journal of Oceanography, 60: 705-718.

Richardson, A. D., Braswell, B. H., Hollinger, D. Y., Jenkins, J. P. \& Ollinger, S. V. (2009). Nearsurface remote sensing of spatial and temporal variation in canopy phenology. Ecological Applications, 19(6): 1417-1428.

Riebesell, U., Zondervan, I., Rost, B., Tortell, P. D., Zeebe, R. E. \& Morel, F. M. (2000). Reduced calcification of marine plankton in response to increased atmospheric $\mathrm{CO}_{2}$. Nature, 407: 364367.

Roberts, J. M., Wheeler, A. J. \& Freiwald, A. (2006). Reefs of the deep: the biology and geology of cold-water coral ecosystems. Science, 312: 543-547.

Roberts, J.M., Henry, L.A., Long, D. \& Hartley, J.P. (2008). Cold-water coral reef frameworks, megafaunal communities and evidence of coral carbonate mounds on the Hatton Bank, north East Atlantic. Facies, 5: 297-316.

Roberts, J., M., Wheeler A., Freiwald, A. \& Cairns, S. (2009). Cold Water Corals. The Biology and Geology of Deepsea Coral Habitats. Cambridge, UK.

Rodolfo-Metalpa, R., Martin, S., Ferrier-Pagès, C. \& Gattuso, J. P. (2010). Response of the temperate coral Cladocora caespitosa to mid-and long-term exposure to $\mathrm{pCO}_{2}$ and temperature levels projected for the year 2100 AD. Biogeosciences, 7: 289-300.

Sabine, CL., Feely, RA., Gruber, N., Key, RM., Lee, K., Bullister, JL., Wanninkhof, R., Wong, CS., Wallace, D., Tilbrook, B., Millero, FJ., Peng, TH., Kozyr, A., Ono, T. \& Rios, AF. (2004). The oceanic sink for anthropogenic $\mathrm{CO}_{2}$. Science, 305: 367-371.

Sherwood, OA., Heikoop, JM., Sinclair, DJ., Scott, DB., Risk, MJ., Shearer, C. \& Azetsu Scott K. (2005). Skeletal Mg/Ca in Primnoa resedaeformis: relationship to temperature? Cold-water Corals and Ecosystems, 1: 173-205. 
Simpson, S. D., Munday, P. L., Wittenrich, M. L., Manassa, R., Dixson, D. L., Gagliano, M. \& Yan, H. Y. (2011). Ocean acidification erodes crucial auditory behaviour in a marine fish. Biology letters, 7: 917-920.

Smith, F. A. \& Raven, J. A. (1979). Intracellular pH and its regulation. Annual Review of Plant Physiology, 30: 289-311.

Steinacher, M., Joos, F., Frolicher, T. L., Plattner, G. K. \& Doney, S. C. (2009). Imminent ocean acidification in the Arctic projected with the NCAR global coupled carbon cycle-climate model. Biogeosciences, 6: 515-533.

Stocker, T. F., Qin, D., Plattner, G. K., Tignor, M., Allen, S. K., Boschung, J. \& Midgley, B. M. (2013). IPCC, 2013: climate change 2013: the physical science basis. Contribution of working group I to the fifth assessment report of the intergovernmental panel on climate change.

Stumpp, M., Trübenbach, K., Brennecke, D., Hu, M. Y. \& Melzner, F. (2012). Resource allocation and extracellular acid-base status in the sea urchin Strongylocentrotus droebachiensis in response to $\mathrm{CO}_{2}$ induced seawater acidification. Aquatic toxicology, 110: 194-207.

Takahashi, A. \& Kurihara, H. (2013). Ocean acidification does not affect the physiology of the tropical coral Acropora digitifera during a 5-week experiment. Coral reefs, 32: 305-314.

Takahashi, T., Sutherland, S. C., Feely, R. A. \& Wanninkhof, R. (2006). Decadal change of the surface water $\mathrm{pCO}_{2}$ in the North Pacific: A synthesis of 35 years of observations. Journal of Geophysical Research: Oceans , 7: 1978-2012.

Tans, P. \& Keeling, R. (2011). Trends in Atmospheric Carbon Dioxide. National Oceanic \& Atmospheric Administration, Earth system Research Laboratory of Global Monitoring Division. Retrieved from: www.esrl.noaa.gov/gmd/ccgg/trends/. Accessed on: 08.10.2015.

Thermo Fisher Scientific Inc (2016). 5-(and-6)-Carboxy SNARF®-1, Acetoxymethyl Ester, Acetate. Retrieved from: https://www.thermofisher.com/order/catalog/product/C1271

Accessed on: 20.02.2016.

Thresher, R. E., Tilbrook, B. D., Fallon, S., Wilson, N. C. \& Adkins, J. (2011). Effects of chronic low carbonate saturation levels on the distribution, growth and skeletal chemistry of deep-sea corals and other seamount megabenthos. Marine Ecology Progress Series, 442:87-99.

Tracey, D. M., Rowden, A. A., Mackay, K. A. \& Compton, T. (2011). Habitat-forming cold-water corals show affinity for seamounts in the New Zealand region. Marine Ecology Progress Series, 430, 1-22.

Tracey, D., Bostock, H., Currie, K., Mikaloff-Fletcher, S., Williams, M., Hadfield, M., Neil, H., Guy, C. \& Cummings, V. (2013). The potential impact of ocean acidification on deep-sea corals and fisheries habitat in New Zealand waters. New Zealand Aquatic Environment and Biodiversity Report No. 117. 101 p. Manuscript 2695 ISBN 978-0-478-42099-9.

Tracey. D., Cummings, V., Barr, N., Moss, G., Neil, H., Marriott, P. Davy, S. \& Gammon, M. (2014). Deep-sea coral live tank experiment. Final Research Report to MPI Project SEA201301 Task CORALS. 9 p. 
Trivedi, B. \& Danforth, W. H. (1966). Effect of $\mathrm{pH}$ on the kinetics of frog muscle phosphofructokinase. Journal of Biological Chemistry, 241: 4110-4114.

Tsien, R. Y. \& Poenie, M. (1986). Fluorescence ratio imaging: a new window into intracellular ionic signaling. Trends in Biochemical Sciences, 11: 450-455.

Venn, A. A., Tambutté, E., Lotto, S., Zoccola, D., Allemand, D. \& Tambutté, S. (2009). Imaging intracellular $\mathrm{pH}$ in a reef coral and symbiotic anemone. Proceedings of the National Academy of Sciences, 106: 16574-16579.

Waller, R. G. \& Tyler, P. A. (2005). The reproductive biology of two deep-water, reef-building scleractinians from the NE Atlantic Ocean. Coral reefs, 24: 514-522.

Wheeler, A.J., Beyer, A., Freiwaid, A, de Haas, H., Huvenne, V.A.I., Kozachenki, M., Olu-LeRoy, K. \& Opderbecke, J. (2007). Morphology and environment of cold-water coral carbonate mounds on the NW European margin. International Journal of Earth Sciences, 96: 37-56.

Winters, G., Holzman, R., Blekhman, A., Beer, S. \& Loya, Y. (2009). Photographic assessment of coral chlorophyll contents: implications for ecophysiological studies and coral monitoring. Journal of Experimental Marine Biology and Ecology, 380: 25-35.

Widdicombe, S. \& Spicer, J. I. (2008). Predicting the impact of ocean acidification on benthic biodiversity: what can animal physiology tell us?.Journal of Experimental Marine Biology and Ecology, 366: 187-197.

Wood, R. (1999). Reef Evolution. Oxford, UK: Oxford University Press. Pp 165-198.

Wood, H. L., Spicer, J. I. \& Widdicombe, S. (2008). Ocean acidification may increase calcification rates, but at a cost. Proceedings of the Royal Society B: Biological Sciences, 275: 1767-1773. 